\title{
UNIVERSITY OF MINNESOTA.
}

AGRICULTURAL EXPERIMENT STATION.

BULLETIN NO. 125.

\section{FARM MANAGEMENT: \\ ORGANIZATION OF RESEARCH AND TEACHING.}

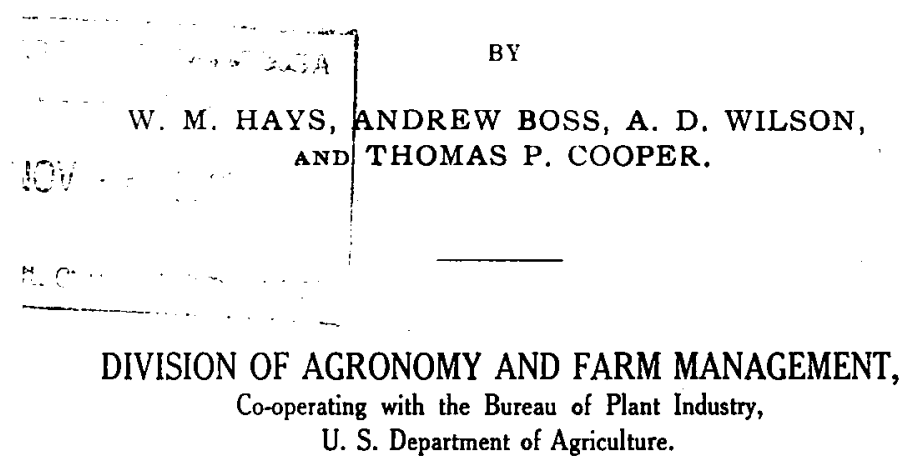

MARCH, 1912.

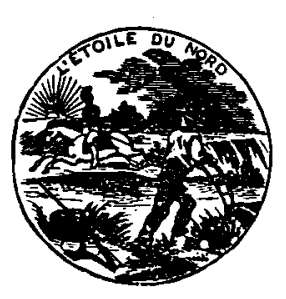




\section{UNIVERSITY OF MINNESOTA.}

THE BOARD OF REGENTS.

GEO. E. VINCENT, LL. D. - - - - - - - - - Ex-Officio

The President of the University.

The HON. JOHN LIND, Minneapolis

The President of the Board.

The HON. ADOLPH O. EBERHART, Mankato -
The Governor of the State.

The HON. C. G. SCHULZ, St. Paul - - - - - - - Ex-Officio

1914

Ex-Officio

The State Superintendent of Public Instruction.

The HON. W. J. MAYO, Rochester - - - - - - - - 1913

The HON. MILTON M. WILLIAMS, Little Falls - - - - - $\quad 1913$

The HON. HENRY B. HOVLAND, Duluth - - _ - - - - 1914

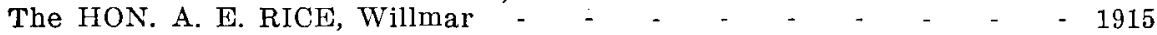

The HON. CHARLES L. SOMMERS, St. Paul - - - - - 1915

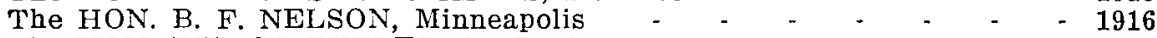

The HON. PIERCE BUTLER, St. Paul - - - - - - - - $\quad$ - 1916

The HON. CHARLES A. SMITH, Minneapolis - - - - - 1916

THE AGRICULTURAL COMMITTEE.

The HON. A. E. RICE, Chairman

The HON. MIILTON M. WILLIAMS

The HON. H. B. HOVLAND

The HON. B. F. NELSON

The HON. PIERCE BUTLER

President GEO. E. VINCENT

A. F. WOODS, A.MI.

STATION OFFICERS.

T. L. HAECKER

M. H. REYNOLDS, B.S., M.D., D.V.M.

ANDREW BOSS

FREDERICK L. WASHBURN, M.A.

E. M. FREEMAN, Ph.D.

JOHN T. STEIVART, C.E.

RALPH HOAGLAND, B.A.

E. G. CHEYNEY, A.B.

LEROY CADY, B.S. in Agr.

C. P. BULL, B.Agr.

H. R. SMITH

R. M. WASHBURN, M.S.A.

CLYDE BAILEY

J. M. DORSEY

L. B. BASSETT

C. C. LIPP, D.V.M.

A. G. RUGGLES, M.A.

J. P. WENTLING, A.II.

R. H. WILLIAMS, MI. S.

A. C. ARNY

W. L. BOYD, D.V.S

W. H. FRAZIER, B.S.

H. P. HOSKINS, V.M.D.

DE FOREST HUNGERFORD, B.S.

CORNELIA KENNEDY, B.A.

A. R. KOHLER, B.S.A.

P. R. MCMILLER, B.S.

J. L. MOWRY

W. L. OSWALD

H. B. ROE, B.S. in Eng.

E. C. STAKMAN, M.A.

G. W. WALKER, B.S. in Chem.

R. M. WEST, B.A.

F. W. WHITE, B.S. in Agr.

L. E. WILLEY, D.V.M.

WARREN WILLIAMSON, M.A.

STEPHEN ANTHONY

MILDRETH HAGGARD, B.A.

W. H. CANTWELL, B.S. in Chem. AGNES ERICSON

GRACE B. ANDREWS

A. J. McGUIRE, B.Agr.

E. C. HIGBIE, M. A.

C. G. SELVIG, M. A.

CHAS. HARALSON

Dairy and Animal Husbandry - - - Veterinary Science Agronomy and Farm Management Entomology

Botany Plant Pathology

Agricultural Engineering Agricultural Chemistry, Soils Forestry

Horticulture

Plant Breeding Animal Husbandry

Assistant in Dairy Husbandry

Flour and Grain Testing

Fruit Breeding

Assistant in Farm Equipment

Assistant in Veterinary Science

Assistant in Entomology Assistant in Forestry

Assistant in Animal Husbandry

Assistant in Farm Crops

Assistant in Veterinary Science Assistant in Soils

Assistant in Veterinary science Assistant in Soils

Assistant in Agricultural Chemistry

Assistant in Horticulture Assistant in Soils

Assistant in Agricultural Engineering Assistant in Agricultural Botany Assistant in Agricultural Engineering Assistant in Pathology Assistant in Soils

Assistant in Agricultural Chemistry Assistant in Animal Husbandry Assistant in Veterinary Science Assistant in Entomology Chemist, Animal Nutrition Chemist, Animal Nutrition

Assistant Chemist, Animal Nutrition Assistant Chemist, Animal Nutrition

Assistant in Animal Nutrition Superintendent Grand Rapids Sub-Station

Superintendent Morris Sub-Station Superintendent Crookston Sub-Station Superintendent Fruit Farm, Excelsior 


\title{
Letter of Transmittal.
}

\author{
Minnesota Experiment Station,
}

St. Anthony Park, April 8, 1912.

Dr. A. F. Woods, Director,

Minnesota Experiment Station,

St. Anthony Park, Minn.

Dear Sir: I have to transmit herewith a paper entitled Farm Management, Organization of Research and Teaching, which is recommended for publication as Minnesota Experiment Station Bulletin No. 125. This paper has been prepared by Professors W. M. Hays, Audrew Boss, A. D. Wilson and Thomas P. Cooper. It is based in part on three lines of work at the State Experiment Station and in the School of Agriculture. It deals directly with:

(a) Investigations to determine the best crop rotation in Minnesota.

(b) Investigations of the cost of producing farm products in Minnesota.

(c) Efforts at devising methods of teaching farm management.

The work has been carried on in co-operation with the Bureau of Plant Industry of the U. S. Department of Agriculture. The aim of the paper is to bring together some of the results of the investigations in these new lines of work that may be useful to farmers in reorganizing their farms, and in installing new methods of management, and also with a view to bringing the subject matter of farm management into better form, making it useful to those who are teaching farm management in the rural and higher agricultural schools. Many farm plans are included which serve as object-lessons in teaching, though the teacher should give class work concerning the organization of the farms which is local to the section. It is believed that this work will prove very useful in stimulating a desire to better plan and systematize the management of many Minnesota farms.

Respectfully submitted,

ANDREW BOSS,

Agriculturist. 
Parme.

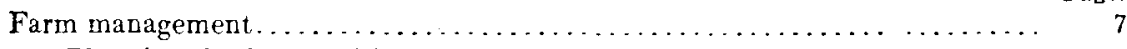

Planning the farm and its business organization.................. 9

Planning fields for the rotation of crops ........................ 11

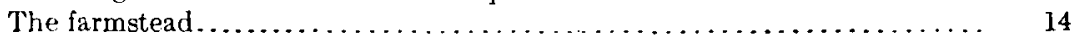

Comparing schemes of crop rotation ............................... 18

Rotation experiments at Lniversity Farm ........................ 20

Comparison of cropping systems tested........................ 26

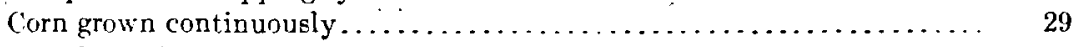

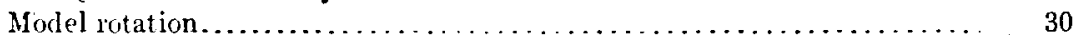

The five-year rotation applied to farm conditions................. 34

Yields of corn, wheat, and hay under different systems of cropping...... 35

Profits increase more rapidly than yields....................... 36

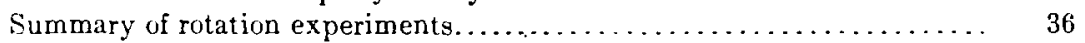

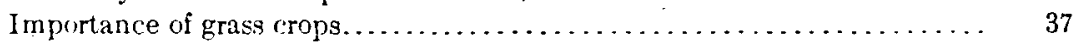

The use of statistics of cost of farm prolucts..................... 39

Methorls of using farm-management data....................... 41

Farm-management investigations needed ....................... 42

Crop-rotation experiments needed.......................... 42

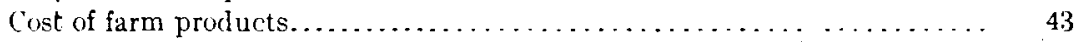

The value of farm products............................. 43

Facts from successful farmers........................... 44

The teaching of farm management............................... 44

Teaching farm organization in consolidated rural schools........... 45.

The key-map method of organizing the farm .................. 50

Teaching farm management in agricultural high schools............. 52

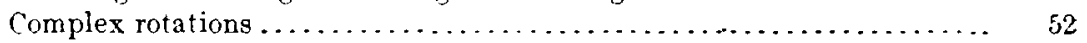

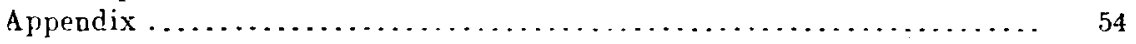

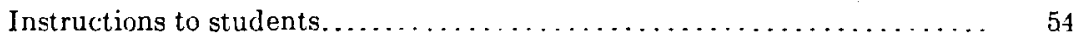

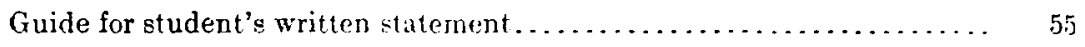

Farm plans made by students............................. 58

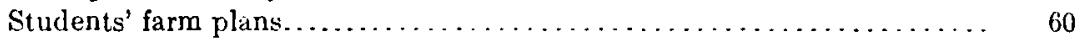

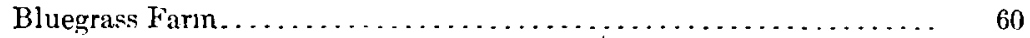

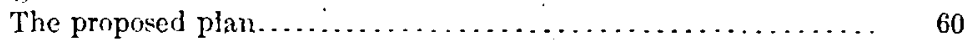

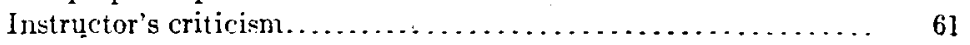

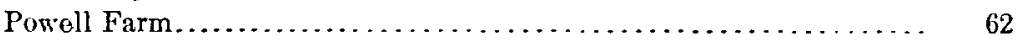

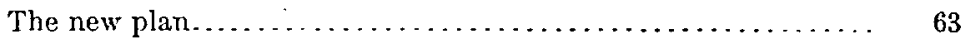

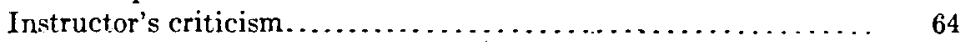

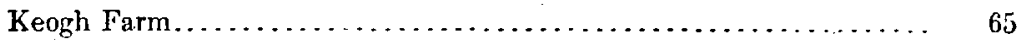

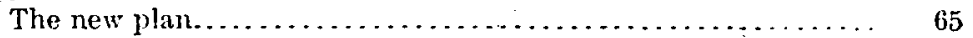

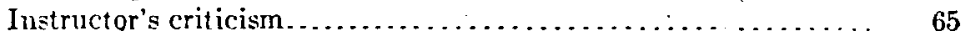

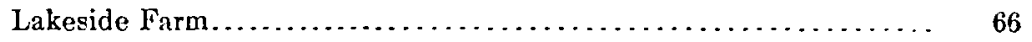

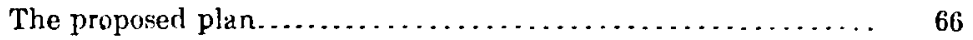

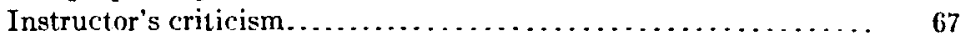

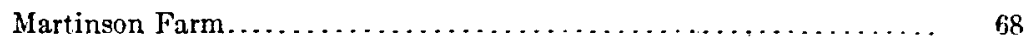

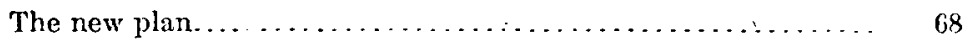

Instructor's criticism................................ 69 
Appendix-Continued.

Students' farm plans-Continued. Page.

Cloverdale Farm ......................................... ${ }_{70}$

Four-year rotation on fields G, H, I, and J............... 71

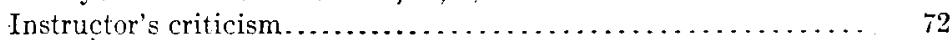

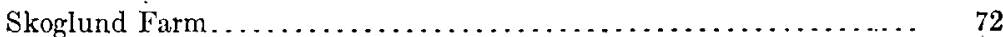

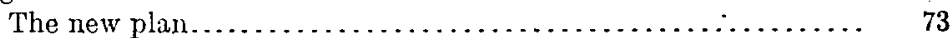

Instructor's criticism..................................... 73

Lake View Farm .......................................... 74

The student's plan ................................... $\quad 75$

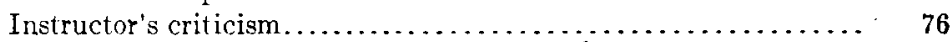

Marple Farm ........................................ ${ }_{77}$

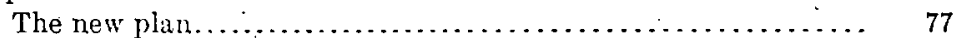

Instructor's criticism................................ 77

Greaves Farm.......................................... 79

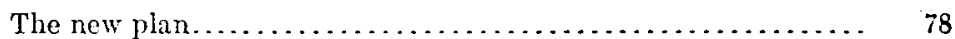

Instructor's criticism................................... 78

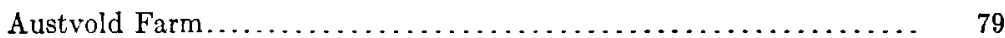

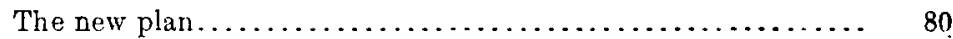

Instructor's criticism ................................. 81

Anthony Farm...................................... 82

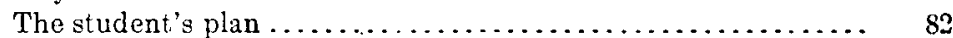

Instructor's criticism................................. 83

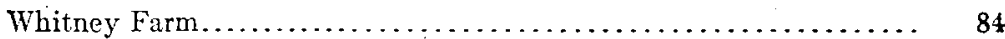

The new plan ..................................... 86

Instructor's criticism .............................. ${ }^{-}$s7

Anderson Farm....................................... 88

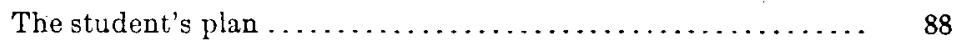

Instructor's criticism................................... 88

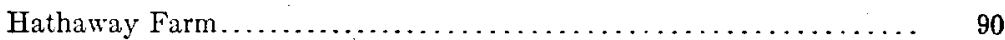

The new plan.................................. 90

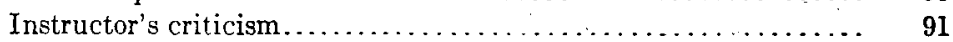

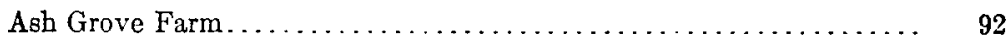

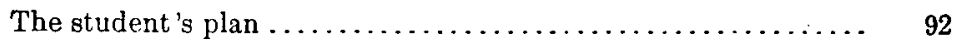

Iństructor's criticism ............................ 93

Pomme de Terre Farm................................. 95

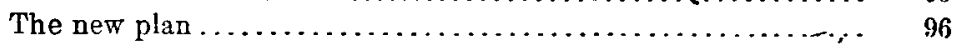

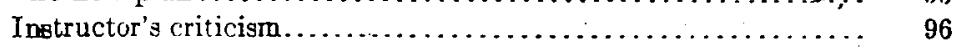




\section{ILLUSTRATIONS.}

'LATES.

Plate I. Fig. 1.-General view of rotation plats at University Farm, St. Paul, Minn. Fig. 2.-General view of model farm experiments.......

II. Fig. 1.-Corn on a five-year rotation plat. Fig. 2.-Shovelful of soil

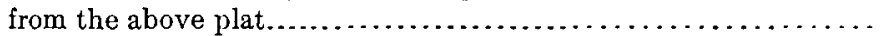

Ii I. Fig. 1.-Corn on a plat growing corn continuously. Fig. 2.--Shovel-

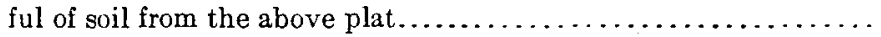

IV. Fig. 1.-Vertical section of soil on plat growing corn continuously. Fig. 2.-Vertical section of suil on plat growing fodder corn on

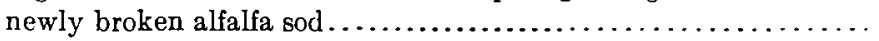

V. Fig. 1.-Vertical section of soil near corn plant growing on newly broken alfalfa sod. Fig. 2.-Timothy sod backset after producing

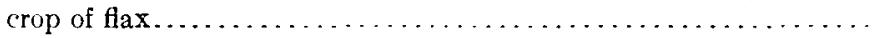

TEXT FIGURES.

Fig. 1. Farmstead on east side of 160 -acre farm

2. Farmstead on northeast corner of 160 -acre farm ................ 15

3. Farm plan, farmstead fronting east ...................... 6

4. Farm plan, farmstead fronting suuth . . . . . . . . . . . . . . . 16

5. Farm plan, farmstead fronting west..................... 17

6. Farm plan, farmstead fronting north . . . . . . . . . . . . . . 17

7. Arrangement of the 44 rotation plats.................... 20

8. Arrangement of plats and system of cropping on the "Model Farm Rotation Experiment" plats......................... 21

9. Unorganized farm; same farm reorganized................. 34

10. Another unorganized farm; same farm reorganized............ 35

11. File case for farm-management students' work............... 46

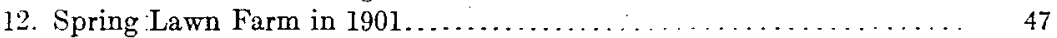

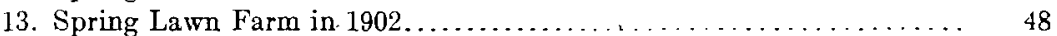

14. Spring Lawn Farm in $1903 \ldots \ldots \ldots \ldots \ldots \ldots \ldots \ldots \ldots \ldots \ldots \ldots . \ldots \ldots \ldots . \ldots \ldots$

15. Spring Lawn Farm. Rotation key map................. 56

16. Spring Lawn Farm. General annual ledger data by fields......... 57

17. Spring Lawn Farm. Manuring schedule................. 58

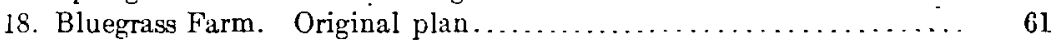

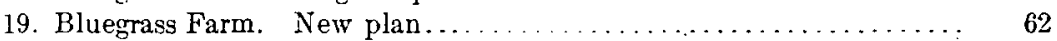

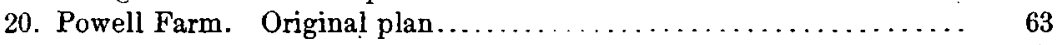

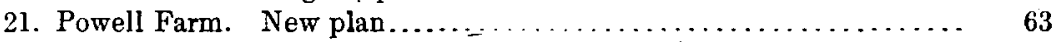

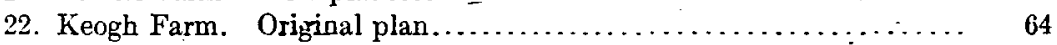

23. Keogh Farm. Student's plan....................... 65

24. Keogh Farm. Revised plan................................ 66

25. Lakeside Farm. Original plan...................... 67

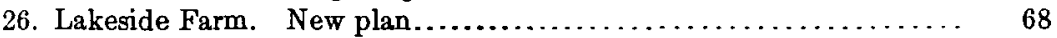

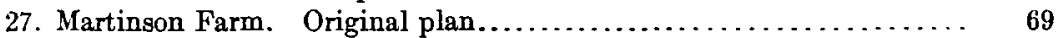

28. Martinson Farm. Student's plan........................... 69 
Fra. 29. Martinson Farm. Reviseil plas...................... ${ }_{70}^{\text {Page. }}$

30. Cloverdale Farm. Revised plan..................... 71

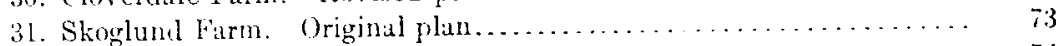

32. Skoglund Firm. Student's plan....................... it

33. Skoglund Farm. Revised plan............................. 75

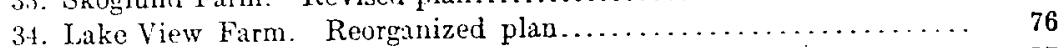

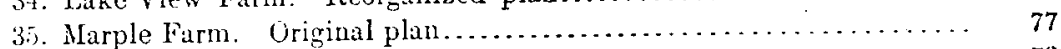

36. Marple Farm. Key map to student's plan................... 78

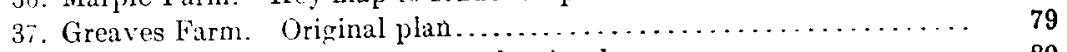

35. Greaves Farm. Key map to student's plan............... 80

39. Greaves Farm. Key map to revised plan ................... 81

40. Austvold Farm. Key map to student's plan............... 82

41. Anthony Farm. Original plan........................ 83

42. Anthony Farm. Key map to student's plan.............. 84

43. Anthony Farm. Key map to revised plan................. 85

44. Whitney farm. Original plan ....................... 85

45. Whitney Farm. Key map to student's plan............... 86

4fj. Whitney Farm. Key map to revised plan.................. 86

47. Anderson Farm. Key map to student's plan................ 87

45. Hathaway Farm. Original plan....................... 90

49. Ilathaway Farm. Key map to student s plan.............. 91

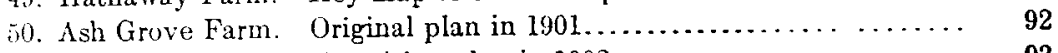

51. Ash Grove Farm. Transition plan in $1902 \ldots \ldots \ldots \ldots \ldots \ldots \ldots \ldots . . \ldots 3$

52. Ash Grove Farm. Transition plan in $1903 \ldots \ldots \ldots \ldots \ldots \ldots \ldots \ldots . . \ldots 4$

53. Ash Grove Farm. Transition plan in $1904 \ldots \ldots \ldots \ldots \ldots \ldots \ldots \ldots . . \ldots 4$

54. Ash Grove Furm. Key map to student's plan, 1905-1912........ 94

5.5. Ash Grove Farm. Key map to revised plan................ 95

56. Pomme de Terre Farm. Original plan.................... 95

57. Pomme de Terre Farm. Key map to new plan............. 96 236 
B. P. 1.-708.

\section{FARM MANAGEMENT: ORGANIZATION OF RESEARCH AND TEACHING.}

FARM MANAGEMENT.

The term "farm management" inclurles the selection, planning, organization, and development of the farm and the daily and yearly conduct of the farm business.

The necessity of knowledge, wisdom, and skill in farm management can not well be overestimated. A European agricultural society found that on many farm estates for which it kept accounts, and for each of which long experience had established true invoice valuations, the net profits were determined mainly by the individual abilities of the respective managers, the net result on the investment ranging from a profit of 12 per cent down to a loss of 3 per cent and averaging 3 per cent profit. In evory farm neighborhood there are examples of men who make a marked success, others who as markedly fail, and still others of all gradations between success and failure, depending far more on the differences in men than on differences in land or in materials, or opportunities, or other conditions.

The object sought in research in farm management is to secure the elementary facts which must be utilized in organizing and conducting the business of the farm in such a way as to give the maximum of products, profits, and enjoyment to the owner and to the farm family, to supply farm products in the best way to all who need them, and gradually to increase the productirity of the soil.

The main purposes in studying farm management are to gain power to analyze the business; to devise suitable systems of cropping, economical arrangements of fields, correct adjustments of field crops to live stock; to utilize capital and labor to the best advantage; to decide upon suitable plans for keeping simple records of the leading projects on the farm; and to carry forward year by year and day br day the management of the farm and the work of farming in such a manner as to give the largest product and the greatest profit per acre and per worker, and decade by decade to increase the productivity of the soil.

An analysis of the average farm business will show it to consist of a large number of separate enterprises or projects, any one of which is a business in itself. That each of these enterprises of ten overlaps every other one renders the farm as a whole a complex business. Into the 
production of income from easl of these projects there enter, inevitably, the factors of man and horse labor; of cash expenditures; of machinery values; of taxes and interest; of depreciation of soil, fences, buildings, machinery, and live stock; and of a variety of other items, any one of which may, by becoming relatively too large, cause a loss for the individual project and perhaps for the farm business as a whole.

For example, with land worth $\$ 75$ per acre and wages of farm labor worth from $\$ 25$ to $\$ 40$ per month, the problem of making profits by raising stock is much more complicated than when land and labor were both cheap. It costs, in Minnesota, from $\$ 20$ to $\$ 35$ per year to feed a cow, from $\$ 8$ to $\$ 12$ per year to milk a cow, from $\$ 3$ to $\$ 8$ per year to market the prorluct, besides care, shelter, interest on investment, and insurance against loss. This makes a charge against cach cow of from $\$ 50$ to $\$ 75$ per year, which shows that a cow to be profitable must yield a gross product considerably above the average. Profitable yieldis of butter and milk are possible, but with the average cow, given average care, the margin of profit is likely to be small. To realize a safo margin of profit, as many farmers are now doing, the cows must be so bred, selected, fed, and cared for as to yield a large product, and the cost of feed and the labor required must be kept well below the ralue of the product. A satisfactory solution requires both a careful study of conditions and good business management. Should such study and such management be lacking, the dairy enterprise may easily suffer a loss sufficient to overbalance the entire grain produced by the general farm business of which dairy production is a part.

The envestigations (a) in crop rotation, $(b)$ in securing lata on the cost of farm products, and (c) in devising methods of teaching farm management, which have served as the specific basis of this bulletin, are pursued in part to aid in teaching farm management and in devising such simplified methods of keeping records with the respective farm enterprises as will actually be used in carrying forward the management of the common farm.

Farm record keeping is a valuable part of farm management, but farm bookkeeping easily becomes so complicated as to be impracticable. Especially is this true on the family farm where the farmer rarely has the bookkeeping habit and does not find it easy either to put down daily a large number of facts or to get time to summarize frequently and make useful a large amount of data. Therefore the mapping system here given is an aid in devising and establishing permanent farm plans at once scientific and practicable, and also the basic form under which to arrange the leading facts which every farm manager should record concerning his fields and the crops grown on them. 
Experience with many students has proven that the plan of maps presented in figures 12 to 17 and further amplified in figures 18 to 57 serve in a most efficient way. both in teaching some of the basic principles of farm management and reorganization, and also in teaching simple methods of keeping the more important records of each of the leading crop projects on the farm. This plan of teaching also serves in assisting the teacher of the country-life school in getting into a vital relation with the parents and in a position often to assist in making a new business plan for a farm which is not paying well. These maps serve somewhat the same purpose in teaching farm management that geometric figures serve in teaching geometry, or that drawings of trusses and pillars serve in teaching bridge engineering.

By recording the general data as to actual yields and prices and applying the figures relating to cost as given in Table XIII in Bulletin 73 of the Bureau of Statistics of the United States Department of Agriculture and Table XIII in Bulletin 117 of the Minnesota Agricultural Experiment Station many comparisons of approximately net profits from different crops and of different rotation schemes can be figured out.

Thus a general plan is provided which the farmer can employ in making comparisons of the profits of projects within his own farm. But posibly of even more importance is the fact that the teacher of agriculture in the consolidated or other school attended by farm youth is thus supplied with formal methods of teaching farm organization and farm management, of recording the results of farm projects, and of comparing profits from the different systems of cropping and the different types of farming in the neighborhood.

\section{PLANNING THE FARM AND ITS BUSINESS ORGANIZATION.}

The primary object of farm planning is to increase profits without proportionately increasing the cost of operation. Since the cost of plowing, rent, seed, seeding, and harvesting are nearly the same for light as for heavy yields, it is plain that under favorable conditions it does not cost twice as much to produce a 50-bushel yield of oats as to produce a 25-bushel yield.

The rotation of crops is one of the simplest, least expensive, and most easily carried out of any of the suggested improvements in agriculture, and the most practical means known, under most farm conditions, of helping to maintain the soil in a high state of productivity. It is by means of the plan of crop rotation, and the plan of joining live-stock production with the cropping scheme, that most of the restoration of productivity of the soil is secured, through the grasses and other soil-building crops and through the return of farm manures to the soil. In some conditions the farm plan makes expenditures 
for commercial fertilizers unnecessary, but in other conditions they are very profitable, both in connection with live-stock farming, and are especially needful in systems of cropping without stock.

In planning fields take into consideration the fact that the nearly square field requires less fencing. On the other hand, that the longer the ficld the more easily the team work is done, and in deciding consider the number of horses used in the fields and the kinds of crops grown. For example, if a field is to be in pasture most of the time, the more nearly square form may be used, while if often plowed and cultivated there is reason for the longer form of field.

Decide upon the area of graiss crops needed, as that will aid in determining the size of fields, thus assisting to decide upon the number of fields and the rotation scheme to adopt.

The change needed on most farms in a new country is to avoid growing grain and cultivated crops continuously on one part of the farm (making the soil lean in vegetable matter) and hay and pasture on another part. Alternating these three classes of crops in an efficient rotation, and thus improving the productivity of the soil, often redices the expense of labor, as of plowing; better distributes the labor throughnut the year, as by growing more crops to be fed out in winter; increases the value of products sold; returns fertility to the soil; increases the yields and enlarges the profits on all parts of the farm.

In helping students in the Minnesota School of Agriculture to make plans for the reorganization of some hundreds of farms, it has often proven unnecessary to chango materially the acreages of the different classes of crops, but rather to divide the fields and rearrange the sequence of the crops already grown.

Choose rather simple rotations with few fields. Three to six year rotations prove best in Minnesota and surrounding States, as large fields are more easily worked than small fields. For certain sections rather complex field systems requiring two or more rotation schemes must be used.

Dixide the tillable lands of the farm into one, two, three, or, in very rare cases into even more, sets of rotation fields, with as many fields for each rotation as there are years required for that rotation, sometimes using two or more small fields to take the place of one rotation field (see figs. 19, 21, 24, 26, 29, 30, 33, 34, 36, 38, 40, 43, $46,47,49,55$, and 57 ).

Hake a special effort to plan the form of fields on broken or hilly land in such a way as to make their cultivation the most practicable, to prevent erosion, and to adapt their sizes to the clesired rotations.

Arrange so that one corner of each field is as near the farmstead as may be, that men and teams may be quickly at work upon leaving the farmstead, and that time may be saved in getting stock to 
and from the fields for pasture, and also to avoid waste of land and fencing in long lanes.

Cse fencing rather freely, even where there is much permanent pasture, so as to secure values of pasturage-as in stubble on grain fielis, or from catch crops, as rape sown among wheat or turnips among flax-often purchasing cattle or sheep to make good use of these secondary crops.

\section{PLANNING FIELDS FOR THE ROTATION OF CROPS.}

Some of the most important considerations to keep in mind in designing arrangements of fields for the rotation of crops are as follows:

Make a historical sketch of the farm, showing the areas in forests, permanent pastures, permanent meadows, and orchards as they now exist; also the location of the farmstead and of the buildings, and the plan of fields and of the crops now growing or last grown. (Figs. 12, 18,20 , and 22.)

Bring as much of the farm under the rotation as possible, that on all fields grain and cultivated crops will be alternated with the meadows and pastures, so that the soil of all fields may be benefited by the growth of grass and leguminous crops

Reclaim or subdue for field crops, in rotation, stony areas, areas in unprofitable trees, areas in which crops are often llowned out, and areas too wet to plow; these may be profitally reclaimed at what may often seem a large expense per acre as the expense of working around these obstructions is avoided.

Plan the farm before developing the farmstead, where this is practicable.

Locate the farmstead of the family-sized farm on the highway near the center of one side rather than at the corner or in the center of the farm, thus avoiding social isolation from being in the center of the farm and the economic loss from being distant from some fields by being at the corner. Thus secure the advantages of being on the highway, where more people will call, of having fields easily accessible on three sides of the farmstead for small pastures, and of having short lanes which give easy access to all fields.

Do not decide on changing the farmstead to a suitable place on the highway if too much is sacrificed, as in buildings, roads, fences, and groves, or where expensive betterments to be made do not justify discarding the old.

Make several trial sketches, showing different possible arrangements of fields and rotation schemes of the farm to be reorganized, to gain different viewpoints of the farm and the farm business, to gain practice in making the plans, and, finally, to decide on a plan at once scientific and practicable. 
Spend some time in devising a suitable plan, and estimate the necessary cost of installing it in order to save useless cxpense in travel to and from ficks, in working awkwardly shaped fields and in poorly arranged farmsteads, and in unnecessary fencing.

Consult with neighbors and with experts in the reorganization and management of farms concerning plans for revising the arrangement of the farm, farm home, and other farm structures, asking criticism of the plans under consideration. This will be both interesting and profitable.

The planning of farms centered in consolidated rural schools will be a most vital subject both from an educational standpoint and from the standpoint of improving the farming of the district.

It will bring the teacher, the pupil, and the farmer into close dis. cussion concerning the farmer's business. It will enable the teacher to become an expert in helping to make plans for the farms in the vicinity. It will lead to discussion and library investigation by the farmers. It will arouse emulation, and eventually much definite information will accumulate from the comparisons between the clear-cut business enterprises on the various farms of the district.

Make a key map $(a)$ with fields arranged for the rotations decided upon, $(b)$ showing the acreage and name of each field, $(c)$ stating the crops which are to appear on each field each year for as many years as are required by the longest rotation, the statement on the fields of the key map to be set ahead some years while the farm is being readjusted to the new forms of fields and the new cropping schemes, as shown in figures $19,21,24$, and others.

Give each field a name, as $A, B, C$, or even a short distinctive proper name, as "Hill field," "End field," "Jones field."

Irake a transition map for each intervening year, in which are projected the gradual changes of fences and crops until the plan projected on the key map has been perfected. (See figs. 13 and 14.)

Make a historical map annually, showing the crops grown, the yields, value, cost, net profits, and other general facts. In ease two crops are grown the same year it is wise to use two maps for each year; and a blank form can be devised and a sufficient number made to last a number of years. (For example of the use of blank forms for historical farm maps, see fig. 16.)

The simple method of making a key map, supplemented with transition maps, and followed annually by a historical map, not only helps to project a good plan of arranging the farm but also serves as a basis of keeping accounts with the enterprise on each field.

The mapping of farms offers ample opportunity for the exercise of good judgment and the use of all one's knowledge regarding the farm business and is splendid as a school subject for training the mind to 
clear thinking as well as to give a clearer knowledge of farm management. This is true in part because it is inspirational and leads to much discussion and to contests in making plans.

Planning farms is a more comprehensive mental exercise than playing chess, which it somewhat resembles, and far more interestiug, since the plan must, in a rather simple way, coordinate all parts of the farm enterprises, must be suited to the farm and the farm family, and must be practicable. so as to lead to a large net income per acre and per worker.

The experience of teachers in charge of agricultural classes proves that farm planning offers a comprehensive and interesting study. Students rooming in dormitories working on plans for the reorganization of their own home farms have been found to consult much more with each other upon this subject than upon other subjects in their school work.

Tho development of engineering methods of reorganizing farms and of teaching farm organization will assist extension workers to serve as efficiency farm engineers, as consulting officers, thus aiding each farmer in installing a good plan of farm layout, an efficient crop rotation scheme, and a profitable general plan, as of a union of live stock and crop farming, or as fruit and regetable farming.

Once the general farm plans are all laid it will be necessary to make changes to meet new conditions as of markets or labor and new plans to adjust divisions of farms into two or more farms or the union of two or more farms. There will also ever be the need of working into closer details, and of arlopting newly inrented machines and newly derised methods.

Formal key-map plans adhered to, and the keeping of cost records which they make possible, will lead to the discovery of those fieldrotation plans and general farm enterprises which do not pay and those which do pay, that the former may be eliminated and that the best of the latter may be chosen for each farm.

Clearer knowledge will lead to the adoption of sizes of farms best for the farm community, recognizing that young people are the greatest crop produced from the land; aroiding on the one hand the farm so small that the owner can not make a satisfactory family income, and on the other hand so restricting the number of family farms as to reduce an unnecessarily large part of the rural community to the status of laborers, restricting their families to the mere income of the farm laborer. Better knowledge of farm management will lead to a happy medium between the farm too small to provide for a division of labor effectively, utilizing horses and motor machinery the year round, and the farm so large that there is an undue proportion 
of the farm families without capital and living on the farm laborwage basis.

The accumulation of scientitic data, local as well as general, should facilitate the cooperative organization of farming under which the laborers supply part of the capital, thus sharing in profits from capital and from managerial enterprise and ability as well as receiving the price earned for labor performed. Definitely ascertained facts concerning the cost of, and profits to, the farm; from cooperation among farmers in the preparation for market and marketing of dairy products, fruits, vegetables, grains, and other products will greatly extend the cooperative doing of those parts of the farm business which can be done most effectively and most economically by collective effort.

TIE FARMSTEAD.

In planning a farmstead plenty of space should be included for
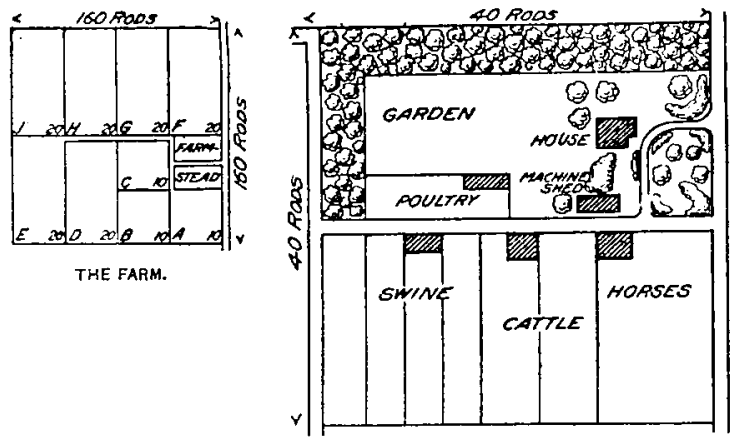

FIG. 1.- Farmstead on east side of 160 -zere farm. A six-year and a three-year rotation on the farm and eight live-stock paddochs on the farmstead. yards, garden, orchard, grove, drives, live-stock paddocks, and similar areas.

Figure 1 shows a farmstead on the east side of. a 160-acre farm, with enlarged view more in detail of the farmstead.

This farmstead occupies 10 acres of land, which is about 6 per cent of the area of the farm. For smaller farms the percentage of area may be somewhat larger and for larger farms the percentage of area may be somewhat smaller than 6 per cent. This is a rather large farmstead, but parts not at once needed for the purposes of the farmstead may be used temporarily for pasture and other crops.

This plan, also the similar plan in figure 2 for the northeast corner of a 160-acre farm, allows a distance of 10 rods between the house and barn and proportionate distances, as shown, between the other buildings, far enough apart for security in case of fire, and yet not too far for doing chores in severe weather. They afford room for a grove 5 or more rods wide on the north and west sides, which should be provided in every prairie-district farm, and also in the northwest on erery timbered-district farm.

Ample room is provided for a garlen. If conditions are right orchard trees may be planted in the farmstead inclosure, or, if better 
conditions of air drainage be required, the orchard may be planted outside the farmstead, preferably on a hillside sloping east or northeast.

A spacious lawn is provided, and some of the leading features in the way of trees and shrubbery are roughly indicated. The large lawn and the ample live-stock paddocks near by give a broad effect to the farmstead.

$A$ lane leading from the public highway connects the horse barn, the cattle barn, the swine barn, and also the machine shed with a lane through which each of the nine fields may be reached in the most direct manner.

There is ample room to enlarge the indicated buildings and to add others. Since most farm animals must be fed from 500 to 1,000 times each year, a slight waste of time at each feeding means a large waste in a year, or in a lifetime. A plan intelligently worked out saves this waste.

Since the farmstead is to be the permanent home of the family, too much attention can hardly be given to making it attractive and interesting, as well as healthful, comfortable, and convenient. The home builder should use the lawn as a canvas and with grass for a

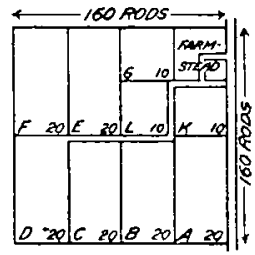

THE FARM.

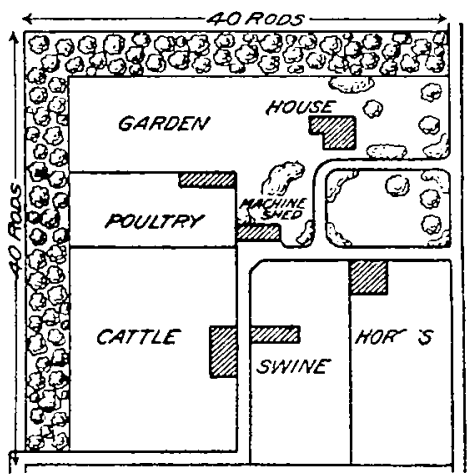

FIG. 2.-Farmstead on northeast corner of 160-acre farm. Six-year and three-yar rotations on nine ficts; also four padrocks.

background use trees, shrubs, and other plants, and also buildings, to paint a picture, beautiful when viewed both from without and from witlin.

Trees should be so arranged as to protect from winds and storms, to provide shade, to add beauty, and to shut out undesirable views, and where practicable openings should be left so that beautiful or interesting things may be seen from the farm home.

Good drainage is one of the first essentials for a location for a farmstead. If the land is not well drained naturally, underdrainage where necessary should be provided and the ground by the buildings should be filled in so that water will run away from the buildings rather than toward them, and broad, open drains should be provided to carry the surface water away quickly.

A low, wet farmstead is unsanitary, frequently causing dangerous diseases. Moreover, there is much more labor and less pleasure in working about yards and barns which often become muddy when drainage would keep them dry. 
Figures $3,4,5$, and 6 illustrate how one general plan of farmstead may be modified so as to

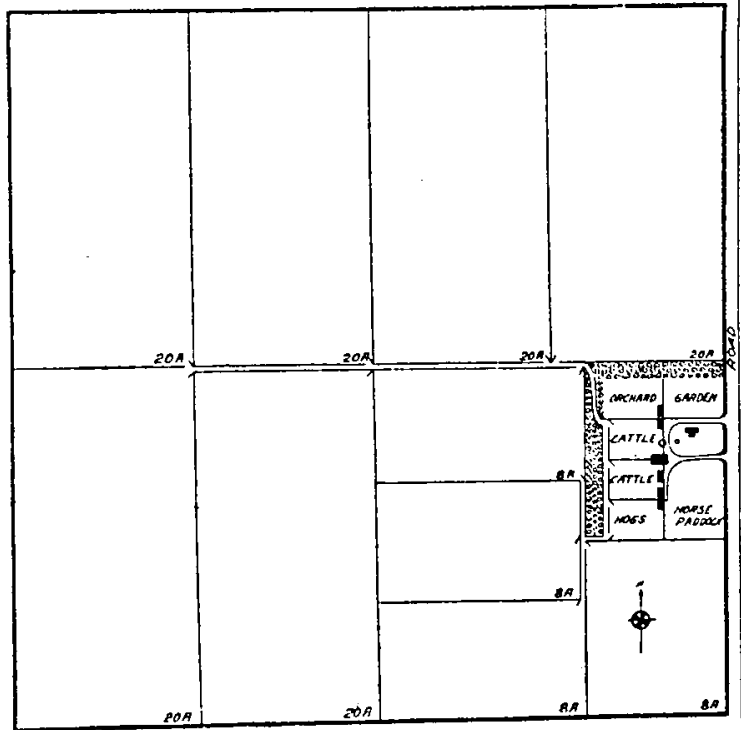

Fig. 3. - Farm plan with six 20 -acre fields, four 8-acre fields, and eight acres in farmstead, fronting east. be conveniently connected with the fielsls from either of the four sides of the farm.

There is great need of investigations and scientific publications presenting the general facts relating to the farmstead, with illustrations as to how best to meet the varied requirements of many farms. The special conditions as of contour, native trees, buildings, and other features already developed, and the proposed amount of present and future expenditure must all be considered. I $t$ is usually wise to remodel rather than radically to change the established farmstead and thius utilize buildings and other expensive improvements.

Each plan must be worked out on the spot, using a scale map, and also stakes lociated so as to show thesize, location, and relation of each building, and other features. Most families get great pleasure out of making a general plim and then gradually working it out as time and means allow.

As different fea-

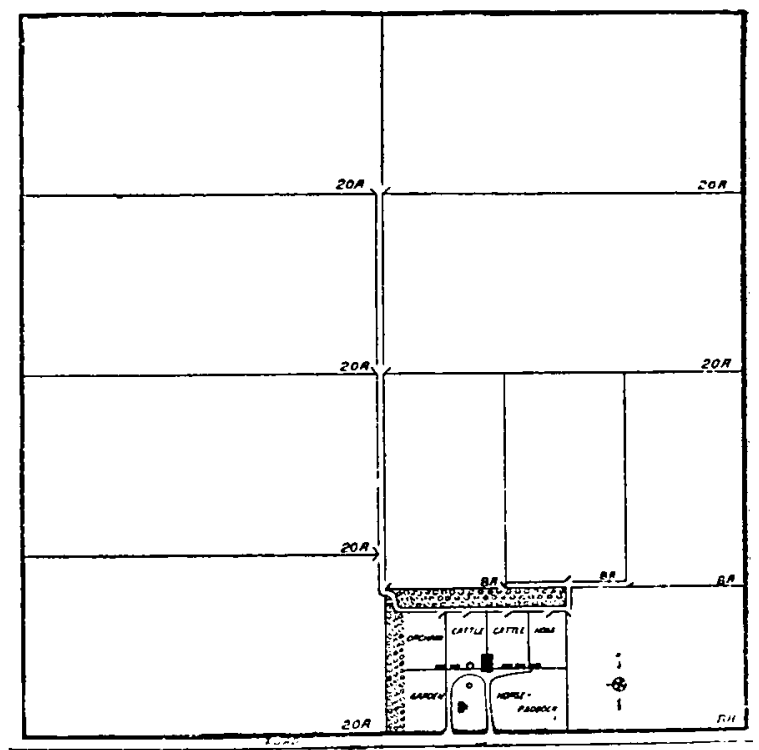

FIG. 4.-Farm pinn with six 20 -acre fields, four 8-acre fields, and eight acres in farmstead, fronting south.

tures of the picture develop, additions may be made, often sug- 
gested by friends, who bring a new viewpoint of this utility, of that prettily planted portion of the grounds, or of some vista which should be better developed so as to add greater charm to the home.

Eren in case of a farmstead already developed, which is not eilsy to change radically, a plan carefully worked out will be found lelpful in making further developments. It is often wise thus to place on a map all the old features, that new features may

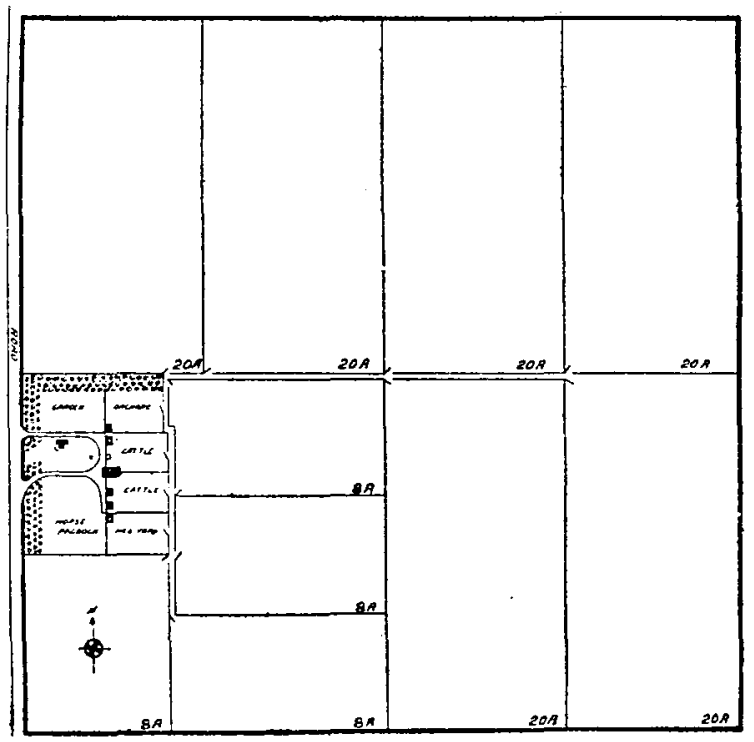

FIG. 5.--Farm plan with six 20-acre fields, four 8-acre felds, and eight acres in farmstead, fronting west.

then be better planned both on the map and on the grounds.

The poultry yard may be in or near the orchard. The orchard, garden, and poultry should be placed near the house to make easy

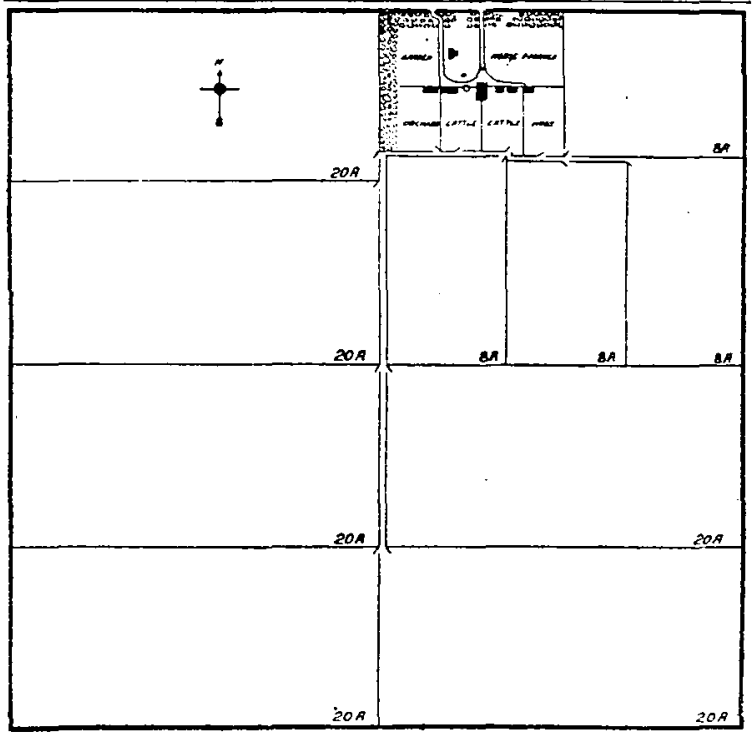

FIG. 6.-Farm plan with six 20-acre fields, four s-acte folds, and eight acres in farmstead, fronting north. the many trips of the housekeeper. It is often wise to arrange so that the poultry can be confined to the orchard during the earlier part of the season, thus to protect the garden.

Two good-sized cattle yards make it practicable to stack grain in one so that the straw may be converted into manure. Iogs should be placed at a considerable distance from the house to avoid

the disagreeable odors which come from the pens. Good-sized hog 16029 - Bull. $236-12-2$ 
y:urds should be provided in the farmstead in which some green crops mity be grown, and these should be connected with the smaller fields which are devoted to raising pasture and other crops, in part to be caten by the hogs.

Much of the grain to be used for food may be stored in the main barn. The best grain should be put in a granary where its germinating vitality will not be injured and where it can be graded that the best may be taken out for seed. This sometimes makes it desirable to hiave a granary separate from the main barn. Separate granaries should be convenient to the horse barn, the cattle barn, and the hog barn.

\section{COMPARING SCHEMES OF CROP ROTATION.}

One of the first and most important things to be done in laying out a system of farm management is to devise a cropping scheme which shill meet the needs of the creneral line of farming to be followed. 'This should so conserve and increase the fertility of the soil as to permanently return the largest possible net profit per acre and per farm worker.

I line of farm management research, begun in 1894, at the Minnesot a Agricultural Experiment Station, is of interest in connection with the organization of farms. $\Lambda$ series of rotation experiments designed to determine the value of various crop rotations illustrates the value of the best of such rotation schemes when compared with the usual one-crop and atherwise poorly arranged systems of farming.

The results of these experiments emphasize the effects of certain (rops upon the soils in which they are grown, illustrating the relatively low productivity of soils in which there is not a fair percentage of compraratively fresh veretable matter.

Tiables I, II, III, and IV, compiled from the results of the rotation experiments, are given to illustrate the varying yields and the consefurnt gains or losses to be secured under good or poor cropping schemes.

Table I, showing the relative yields per acre of wheat when grown in five separate cropping schemes, illustrates the fact that the soil is prepared for each crop by the crop preceding it, by the cultivation given that crop, and by the entire series of crops in the rotation. Table II gives the yields of corn when grown under the conditions of three different rotations.

To get the average value of crops from each of the rotations given In 'Tables I and II, the yield of the crop grown each year was multiplicd by the average farm price for December 1 for 10 years as recorded in the Yearbook of the Lnited States Department of Acriculture, thus placing all crops on a comparable basis as to prices uned in making the calculations. In case of crops for w'lich the Department of Airriculture gives no quotations, the value per acre was detamined by such current prices as could be secured. 
TABLE I.- Yields of wheat from five cropling schemes, average six yeors, 1899-190\%.

\begin{tabular}{|c|c|c|c|c|c|}
\hline Yeur. & $\begin{array}{l}\text { Wheat con- } \\
\text { tinuously, } \\
\text { no manure. }\end{array}$ & $\begin{array}{c}\text { Two-year } \\
\text { rotation: } \\
\text { Wheat and } \\
\text { maingcls, } \\
\text { no manure. }\end{array}$ & $\begin{array}{l}\text { Threc-year } \\
\text { rotation: } \\
\text { Corn, } \\
\text { wheat, } \\
\text { clover, } \\
\text { no manure. }\end{array}$ & $\begin{array}{l}\text { Two-year } \\
\text { rotution: } \\
\text { Wheat, } \\
\text { annual } \\
\text { pasture, } \\
\text { no manure. }\end{array}$ & $\begin{array}{l}\text { Five-year } \\
\text { rotation: } \\
8 \text { tons } \\
\text { manure } \\
\text { and coln, } \\
\text { wheat, } \\
\text { meadow, } \\
\text { pasture, } \\
\text { oats. }\end{array}$ \\
\hline 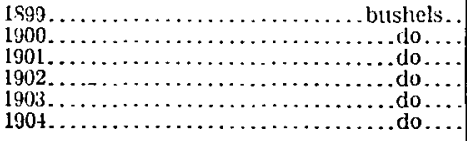 & $\begin{array}{l}22.5 \\
14.5 \\
16.0 \\
17.0 \\
16.3 \\
20.8\end{array}$ & $\begin{array}{l}24.2 \\
13.5 \\
15.1 \\
21.3 \\
19.1 \\
20.0\end{array}$ & $\begin{array}{l}20.9 \\
27.3 \\
13.7 \\
18.1 \\
24.4 \\
27.3\end{array}$ & $\begin{array}{l}27.0 \\
29.5 \\
17.8 \\
23.1 \\
28.8 \\
28.6\end{array}$ & $\begin{array}{l}27.3 \\
25.6 \\
15.2 \\
25.1 \\
30.8 \\
32.0\end{array}$ \\
\hline 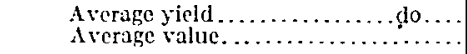 & $\begin{array}{l}17.8 \\
811.80\end{array}$ & $\begin{array}{l}13.9 \\
\$ 12.41\end{array}$ & $\begin{array}{l}21.9 \\
814.76\end{array}$ & $\begin{array}{l}25.8 \\
\$ 16.99\end{array}$ & $\begin{array}{l}26.0 \\
817.44\end{array}$ \\
\hline 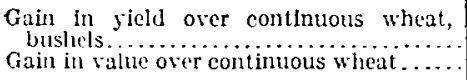 & & $\begin{array}{l}1.1 \\
80.61\end{array}$ & $\begin{array}{c}4.1 \\
82.90\end{array}$ & $\begin{array}{c}8.0 \\
85.19\end{array}$ & $\begin{array}{c}8.2 \\
55.64\end{array}$ \\
\hline
\end{tabular}

In Table I it will be observed that the yields of wheat from these cropping systems varied from an average of 17.8 bushels per acre from continuous wheat cropping without manure to 26 bushels per acre from the 5-year rotation manured once in 5 years. Also, that each rotation system gives larger yields than does the continuous cropping to wheat. Compared with the continuous wheat cropping, the 2-year rotation (first year, wheat; second year, mangels) gave an increased yield of 1.1 bushels. The 3-year rotation (first year, corn; second year, wheat; third year, clover) gave an increased yield of 4.1 bushels. The 2-year rotation (first year, wheat; second year, annual pasture) gave an increased yield of 8 bushels; and the 5 -year rotation (first year, 8 tons manure, corn; second year, wheat; third year, meadow; fourth year, pasture; and fifth year, oats) gave an increased yield of 8.2 bushels.

TABLE II._Comparison of jïields of corn grown continuously with corn grown in three and five year rotations for five years."

\begin{tabular}{|c|c|c|c|}
\hline Year. & $\begin{array}{l}\text { Corn con- } \\
\text { tinuously, } \\
\text { no manure. }\end{array}$ & $\begin{array}{l}\text { Corn in } \\
\text { 3-year } \\
\text { rotation: } \\
\text { Com, } \\
\text { wheat, } \\
\text { clover. }\end{array}$ & $\begin{array}{c}\text { Corn in } \\
\text { 5-year } \\
\text { rotation: } \\
\text { Manure, } \\
\text { com, } \\
\text { wheat, } \\
\text { meadow, } \\
\text { pasture, } \\
\text { oats. }\end{array}$ \\
\hline 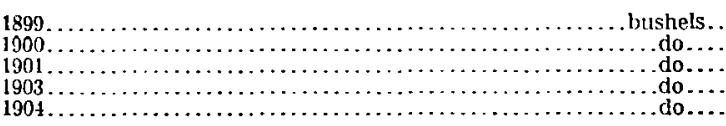 & $\begin{array}{l}20.8 \\
37.5 \\
13.9 \\
23.6 \\
11.1\end{array}$ & $\begin{array}{l}51.1 \\
42.6 \\
42.0 \\
54.7 \\
45.1\end{array}$ & $\begin{array}{l}31.3 \\
58.0 \\
42.8 \\
85.3 \\
37.1\end{array}$ \\
\hline 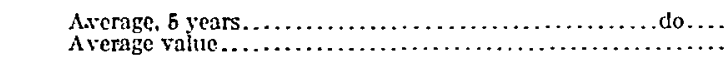 & $\begin{array}{l}21.4 \\
87.04\end{array}$ & $\begin{array}{r}47.1 \\
\$ 16.11\end{array}$ & $\begin{array}{r}50.9 \\
\$ 17.89\end{array}$ \\
\hline 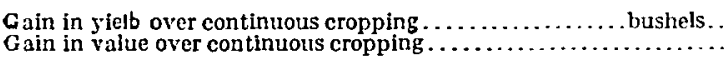 & $\begin{array}{ll}\ldots \\
\ldots \ldots\end{array}$ & $\begin{array}{l}25.7 \\
\$ 9.10\end{array}$ & $\begin{array}{l}29.5 \\
810.88\end{array}$ \\
\hline
\end{tabular}


In Table II the difference in yield between corn grown continuously and corn grown in rotation is even greater than in case of the wheat. The common belief that corn does fairly well when continuously grown on the same soil without manure is not sustained by this inves-

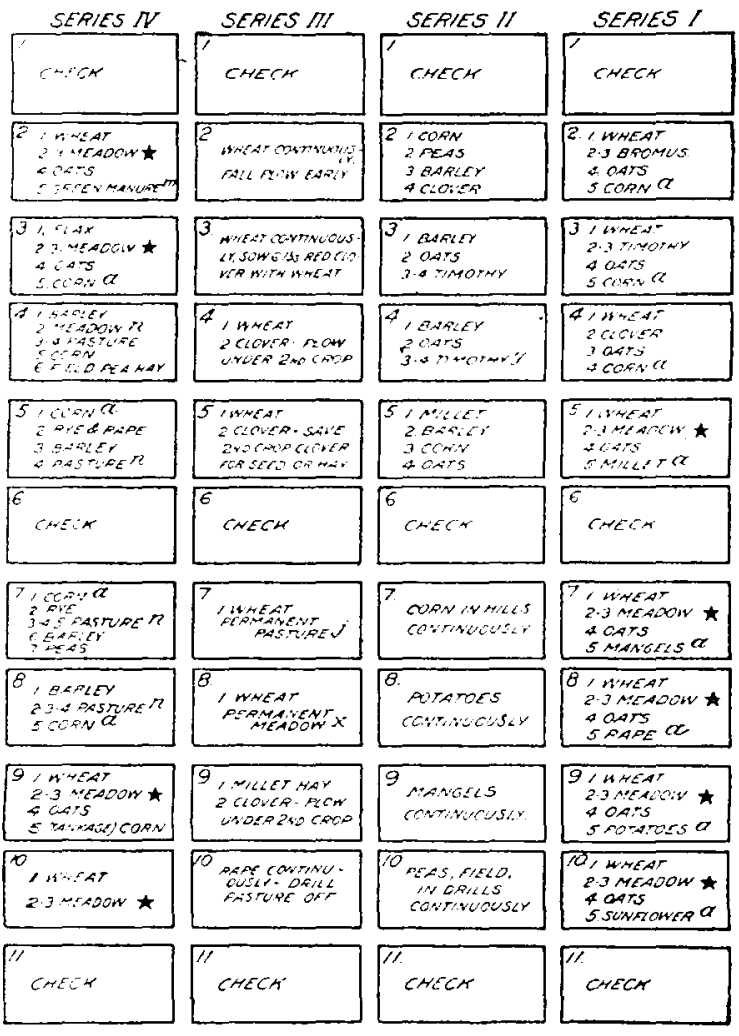

Flri :- - trangement of the 4 thotation plats; also system of cropping

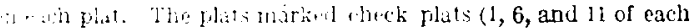

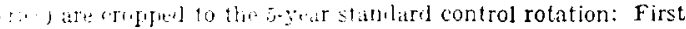

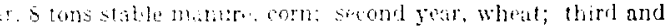

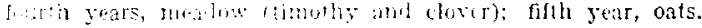

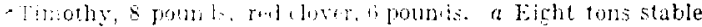

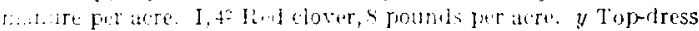

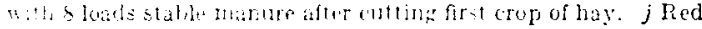

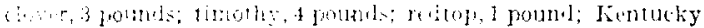

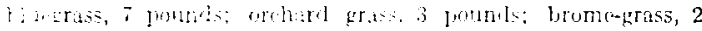

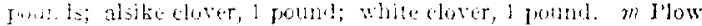

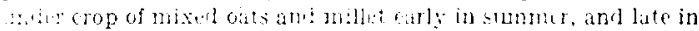

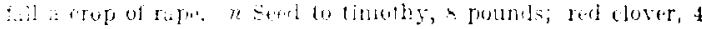

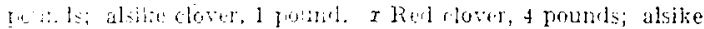

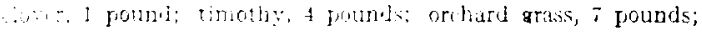

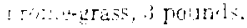

tigation. The average difference was 25.7 bushels in favor of the 3 -year ratation and 29.5 bushels in faror of the 5-year rotation. Wheat grown in rotation yielded a product worth from $\$ 0.61$ to $\$ 5.64$ per acre more than did wheat grown continuously on a near-by plat; and corn grown in rotation yielded from $\$ 9.10$ to $\$ 10.88$ per acre more than corn grown continuously.

The above are radical examples, but they illustrate most forcibly the general fact that there are wrong methods as well as right methods of cropping. The entire net profit is often lost because of wrong methods of cropping, and many farms do not pay because the arrangement of crops or their lack of arrangement in rotation is not suited to each crop, so that each and all may yield a profit.

\section{ROTATION EXPERIMENTS AT UNIVERSITY FARM.}

The rotations herein discussed are on a 12-acre field of land planted as indicated in figure 7 . (See alio Pl. I.) These rotation plats were inangurated in the spring of 1894 and are to continue indefinitely. 


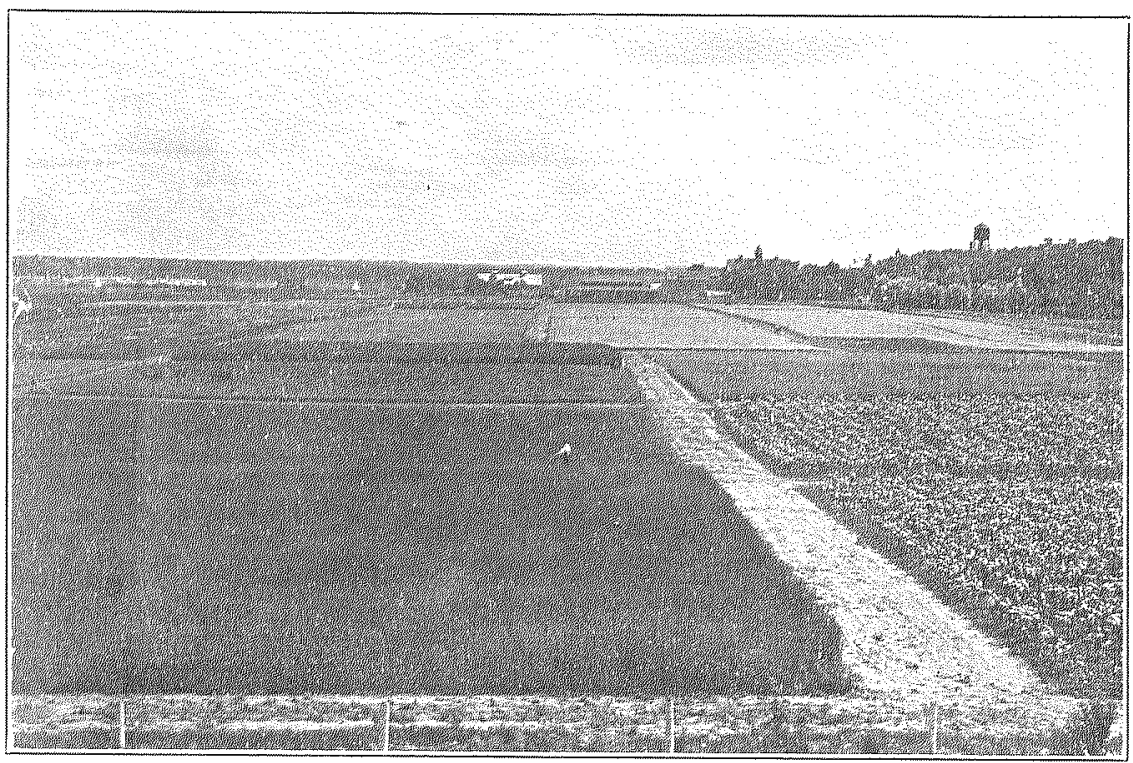

FIG, T, GENERAL VIEW OFROTATION PLATSATUNIVERSITYFARM, ST. PAUL, MINN

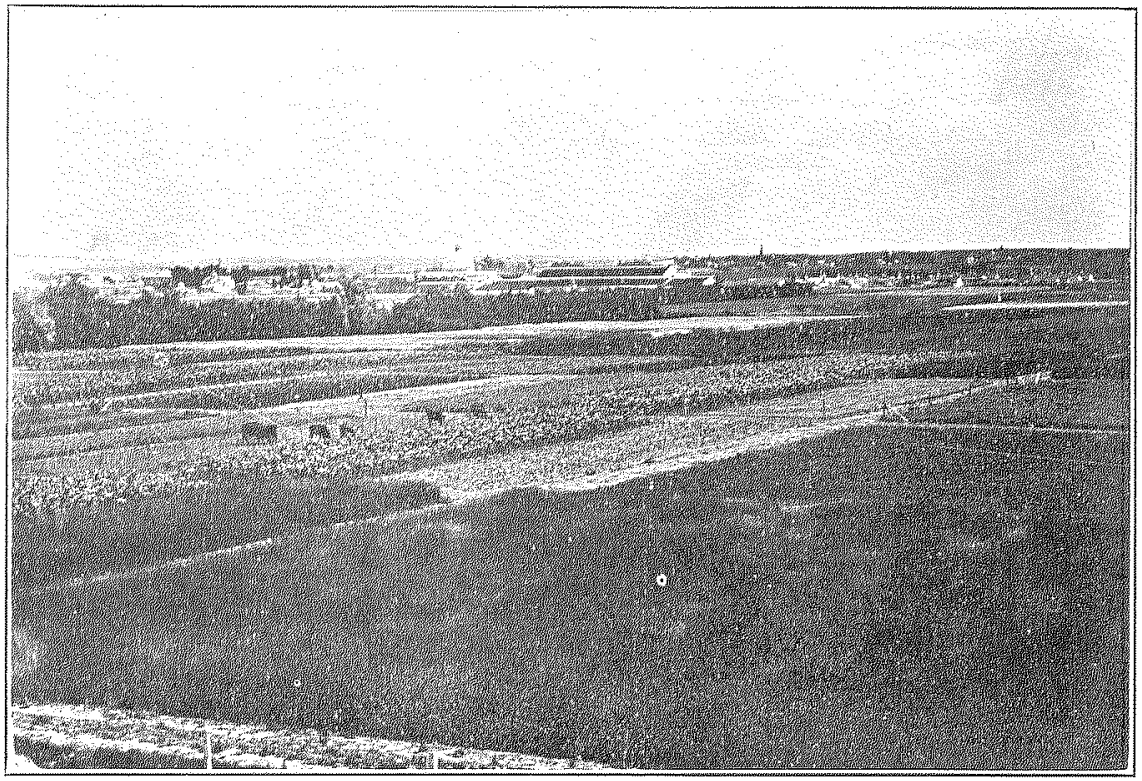

FIG. 2,-GENERAL VIEW OF MODEL. FARM EXPERIMENTS. 
As shown in figure 7, there are 44 plats, 11 in each of the 4 series. On plats 1, 6, and 11, of each series, marked "check" there was placed a standard rotation, which served as a basis of comparison for the intervening plats. This standard rotation covers 5 ycars, as ollows: First year, corn; second year, wheat; third year, timothy and clover meadow; fourth year', pasture; and fifth year, oats. 'The practicability of this rotation is shown by the fact that in this course of cropping the land became rather more productive, the yields of crops were sustained, and an analysis of the soil in 1895 and again in 1904 showed an increase of several hundred pounds of nitro-

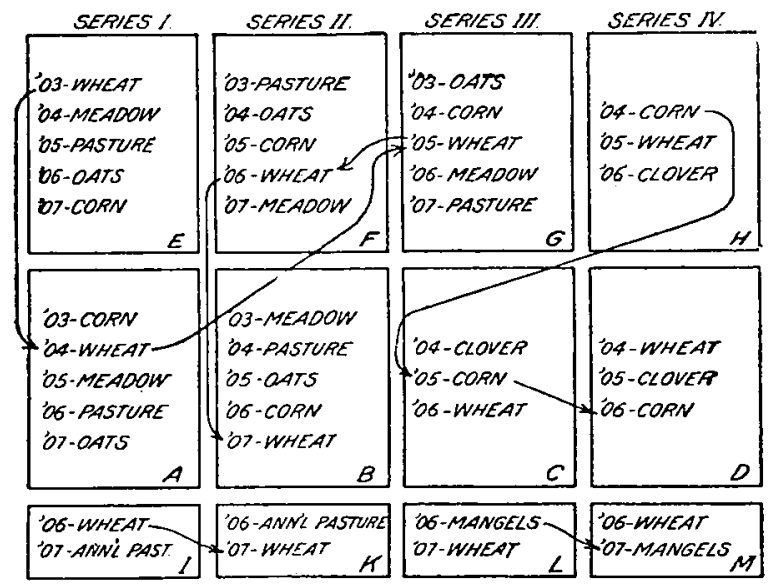

FiG. 8.-Arrangement of plats and system of cropping on the "Model Farm Rotation Experiment" plats. Sequence shown by arrows.

gen per acre and of a few thousand pounds of carbon per acre, thus showing an increase in the vegetable matter in the soil. (Pls. II and III.)

The annual yields of the standard rotation for the 10-year period, 1900 to 1909 , were valued at $\$ 15.89$ per acre while the cost was $\$ 10.02$, leaving a net income of $\$ 5.87$, after paying $\$ 3.50$ rent and all other expenses of operation.

It is significant that this standard rotation is almost an average of 14 cropping schemes which yielded a net return of more than $\$ 5$ per acre for the 10-year period, 1900 to 1909. In it are combined one cultivated crop, two grain crops, and two grass crops, making it typical of the general system of cropping which pays best in a large part of Minnesota. 
$T_{A B 1 E}$ III.-Comparisons of 28 cropping schemes with the standard rotation, showing profits and losses; also gaivs and losscs of carbon and nitrogen-experiment covering a continuous period.

CROPPING SCHEMES YIELDING NET AVERAGE ANNUAL INCOME OF OVER \$5.

\begin{tabular}{|c|c|c|c|c|c|c|c|c|c|}
\hline 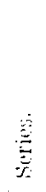 & $\stackrel{\Xi}{\Xi}$ & Rotation scheme. & $\begin{array}{c}\text { Net } \\
\text { profit } \\
(+) \text { or } \\
\text { net loss } \\
(-), \\
1000- \\
1009 .\end{array}$ & $\begin{array}{c}\text { Net } \\
\text { profit } \\
(+) \text { or } \\
\text { net loss } \\
(-) . \\
1890- \\
1899 .\end{array}$ & $\begin{array}{l}\text { Net } \\
\text { profit } \\
(+) \text { or } \\
\text { net loss } \\
(-) \\
1906- \\
1904 .\end{array}$ & $\begin{array}{l}\text { Net } \\
\text { profit } \\
(+) \text { or } \\
\text { net loss } \\
(-) \text {. } \\
1905- \\
1909 .\end{array}$ & $\begin{array}{c}\text { Loss } \\
(-) \\
\text { or gain } \\
(+) \text { of } \\
\text { nitro- } \\
\text { gen, } \\
1895- \\
1904 .\end{array}$ & $\begin{array}{c}\text { Loss } \\
(-) \\
\text { or gain } \\
(+) \text { of } \\
\text { carbon, } \\
1895- \\
1904 .\end{array}$ & $\begin{array}{l}\text { When } \\
\text { manured. }\end{array}$ \\
\hline I & 9 & dow; 4, & & & & & $\begin{array}{c}\text { Per } \\
\text { cent. }\end{array}$ & $\begin{array}{c}P c r \\
c e n t .\end{array}$ & \\
\hline$V^{2}$ & & oa & $+\$ 8.11$ & $+\$ 2.31$ & $+\$ 6.45$ & $+\$ 9.77$ & +0.008 & & $1899,1904,1909$. \\
\hline 1. & 8 & $2,3,4$, pasture; 5 & & & & +0.15 & .011 & +0.16 & \\
\hline II I & & corn......................... & +6.41 & +3.59 & +7.02 & +5.79 & +.016 & & $1899,1905$. \\
\hline & 3 & $\begin{array}{l}\text { clover; save sec- } \\
\text { clover for seed ... }\end{array}$ & +6.15 & $1+7.05$ & +10.83 & +1.47 & +.035 & +.31 & \\
\hline IV & 5 & $\begin{array}{l}1 \text {, corn; } 2 \text {, rye and rape; } 3 \text {, } \\
\text { barler; } 4 \text {, pasture........ }\end{array}$ & +6.03 & +8.11 & +4.19 & +7.83 & +.022 & & $1900,1904,1948$. \\
\hline II & 3 & $\begin{array}{l}1, \text { barley } ; 2, \text { oats } ; 3,4, \text { timo- } \\
\text { thy } \ldots \ldots \ldots \ldots \ldots \ldots \ldots \ldots\end{array}$ & +5.97 & +6.70 & +6.28 & +5.66 & & +.11 & \\
\hline$I$ & $\bar{j}$ & 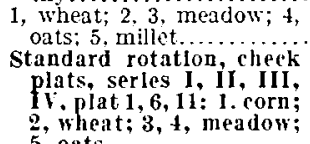 & +5.91 & +8.32 & +7.16 & $+\stackrel{4}{4.68}$ & $\div .025$ & & $1899.1904,1909$. \\
\hline II & 4 & $\begin{array}{r}5 \text {, oats } \\
1 \text {, barles; } 2 \text {, oats; } 3,4 \text {, timo- }\end{array}$ & +5.87 & +6.97 & +5.88 & +5.86 & +.015 & & $1890,1004.1909$. \\
\hline IV & 3 & 3 meadow; 4 , oats; & $1+$ & + & & & & $+\ldots$ & \\
\hline I] & $\vec{i}$ & $\begin{aligned} 5, c 0 \\
\text { 1. whe }\end{aligned}$ & $\begin{array}{l}+5.58 \\
+5.36\end{array}$ & $\begin{array}{l}+6.50 \\
+3.55\end{array}$ & $\begin{array}{l}+6.77 \\
+4.75\end{array}$ & $\begin{array}{l}+4.62 \\
\div 6.58\end{array}$ & $\begin{array}{l}+.014 \\
+.004\end{array}$ & +.07 & $1899,1904,1909$. \\
\hline & & $\begin{array}{l}\text { 1, wheat; } 2,3 \text { meadow; } 4 \text {, } \\
\text { oats: } 5 \text {, green manure.... }\end{array}$ & +5.29 & +8.93 & $1+3.93$ & +6.67 & +.025 & +.05 & \\
\hline III & 4 & 1. Wheat, 2 clover; plow un- & $1+5$ & +5 & & $1+$ & +.035 & +31 & \\
\hline IS & $\vec{r}$ & $\begin{array}{l}\text { 1. corn: } 2 \text { rye; } 3,4,5 \text {, pas- } \\
\text { ture; } 0 \text {, barley: } 7 \text {, peas... }\end{array}$ & +5.11 & +8.14 & +6.75 & +3.47 & +.027 & & $1901,1908$. \\
\hline
\end{tabular}

CROPPING SCHEMES YIELDING NET AVERAGE ANNUAL INCOME OF OVER 3.

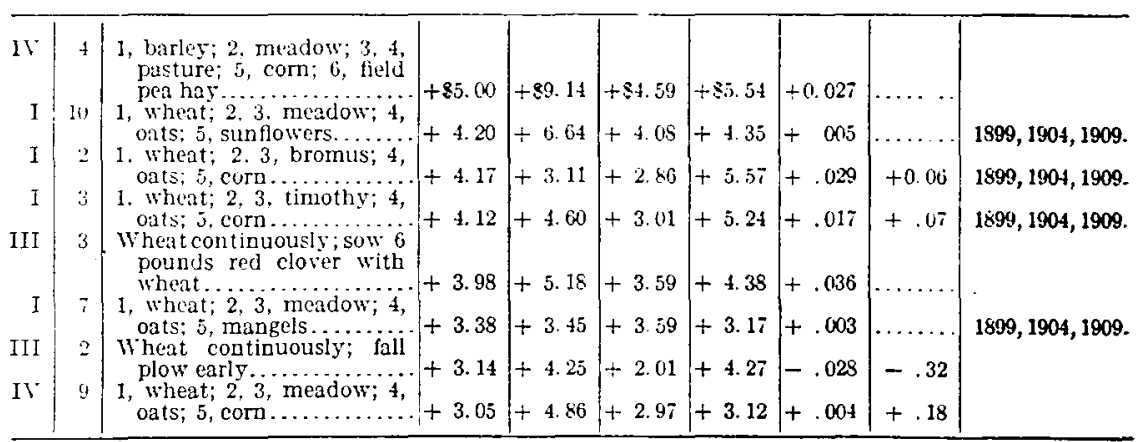

CHOPPING SCHEAES YIELDING NET AVERAGE ANNUAL INCOME OF LESS THAN 3.

\begin{tabular}{|c|c|c|c|c|c|c|c|c|}
\hline II I & $\frac{6}{10}$ & $\begin{array}{l}\text { Wheat; permanent meadow. } \\
\text { Field peas in drills continu- } \\
\text { ously } \ldots \ldots \ldots \ldots \ldots \ldots \ldots\end{array}$ & $\begin{array}{l}+\$ 2.62 \\
+1.42\end{array}$ & $\begin{array}{l}+\$ 4.92 \\
+\quad .17\end{array}$ & $\begin{array}{l}+\$ 3.30 \\
-1.81\end{array}$ & $\begin{array}{l}+\$ 1.76 \\
+2.69\end{array}$ & 0.003 & $\begin{array}{l}+0.06 \\
\ldots \ldots\end{array}$ \\
\hline
\end{tabular}

CROPPING SCHEMES SHOWING POSITIVE LOSS.

\begin{tabular}{|c|c|c|c|c|c|c|c|c|}
\hline II & 7 & Com in hills, con tinuausly. & $-\$ 1.47$ & $+\$ 1.08$ & -82.71 & -80.48 & -0.040 & -0.54 \\
\hline 111 & 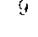 & $\begin{array}{l}\text { 1, millet hay; } 2 \text {, clover; plow } \\
\text { under second crop. . . . }\end{array}$ & -2.03 & -1.70 & -2.53 & -.16 & +.007 & \\
\hline III & iut & $\begin{array}{l}\text { Rape continuously; irill- } \\
\text { pasture off. } \ldots \ldots \ldots \ldots \ldots\end{array}$ & & & -2.40 & & & +.10 \\
\hline $1 \mathrm{IJ}$ & 6 & Potatoes continuously. & -3.17 & +3.16 & -.16 & -4.96 & -.034 & -.66 \\
\hline II & $\theta$ & Nangels continuously. & -14.55 & -9.77 & -12.51 & -16.59 & -.033 & -.45 \\
\hline
\end{tabular}




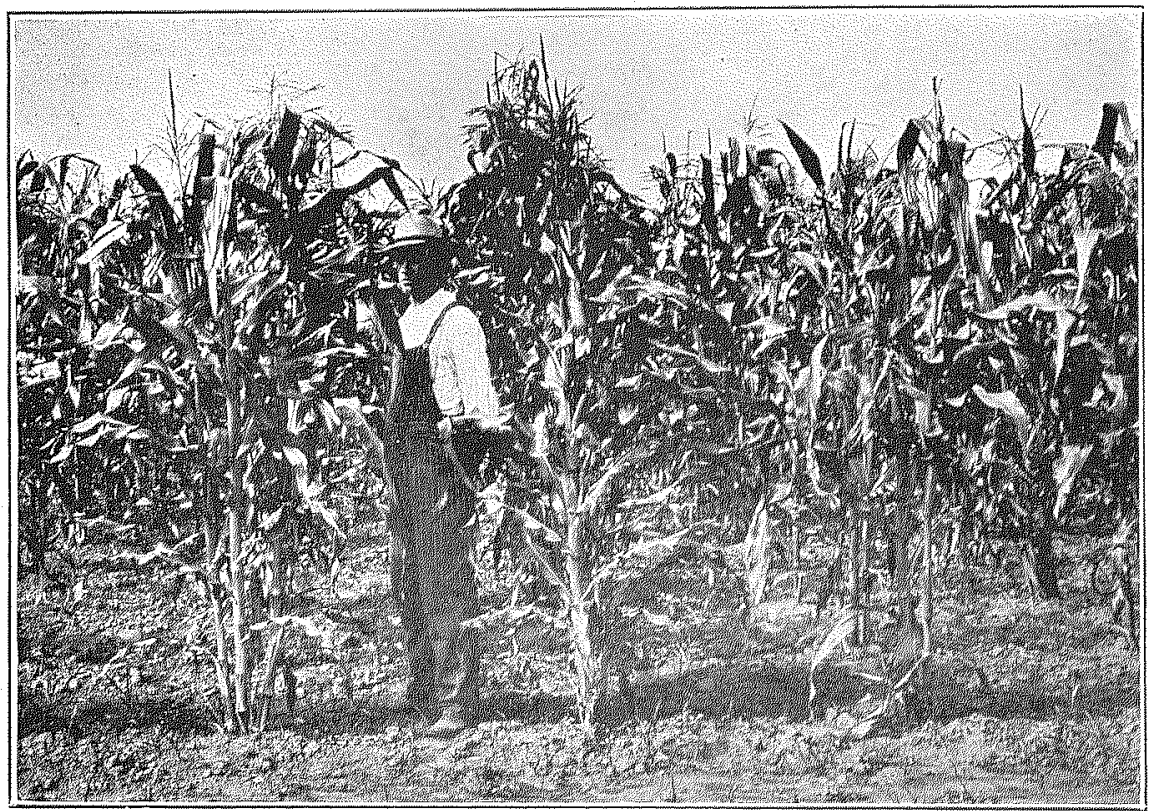

FIG 1......CORN ON A FIVE-YEAR ROTATION PLAT.

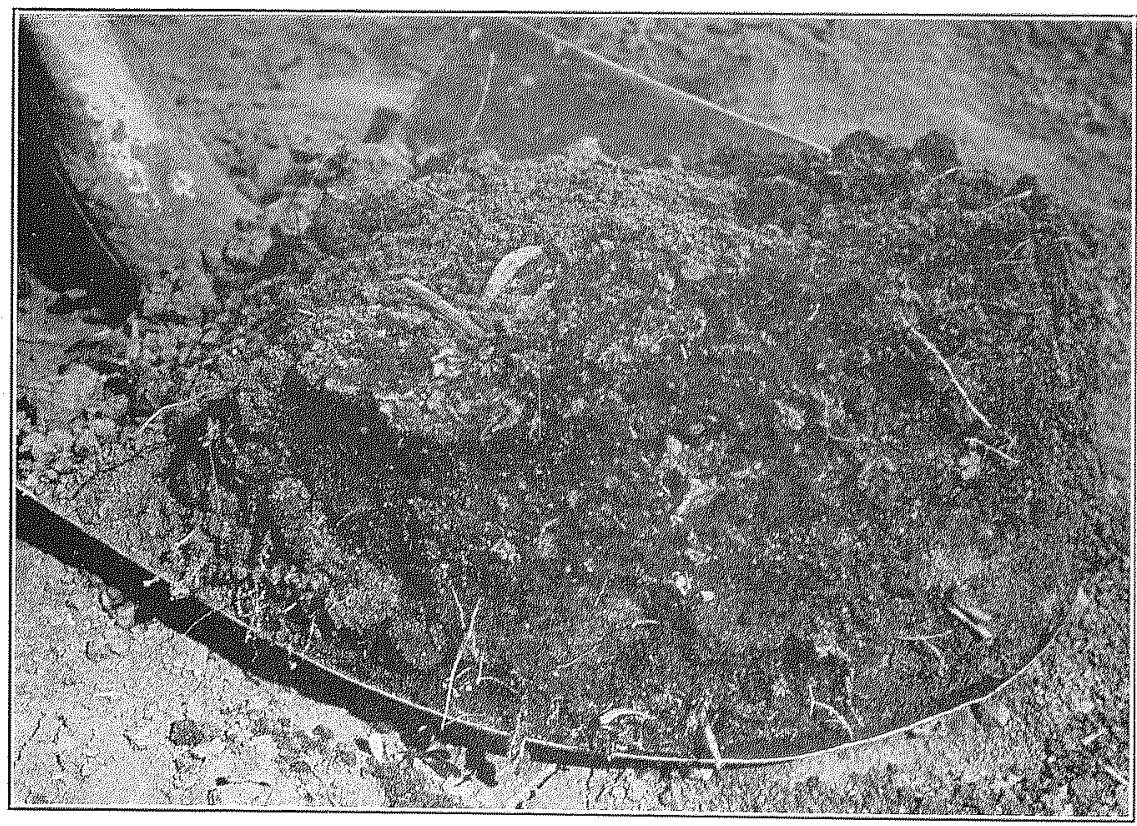

FIG. 2-SHOVELFUL OF SOIL FROM THE ABOVE PLAT. 


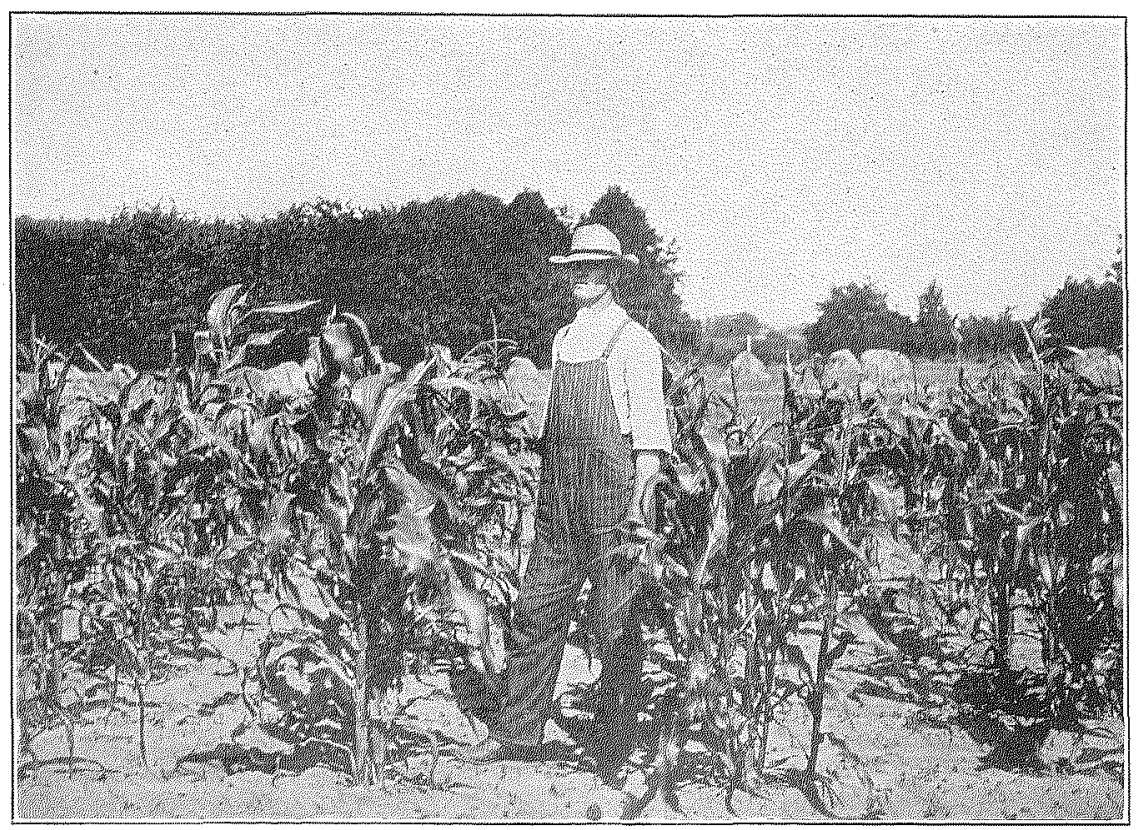

FIG. I-CORN ON A PLAT GROWING CORN CONTINUOUSLY.

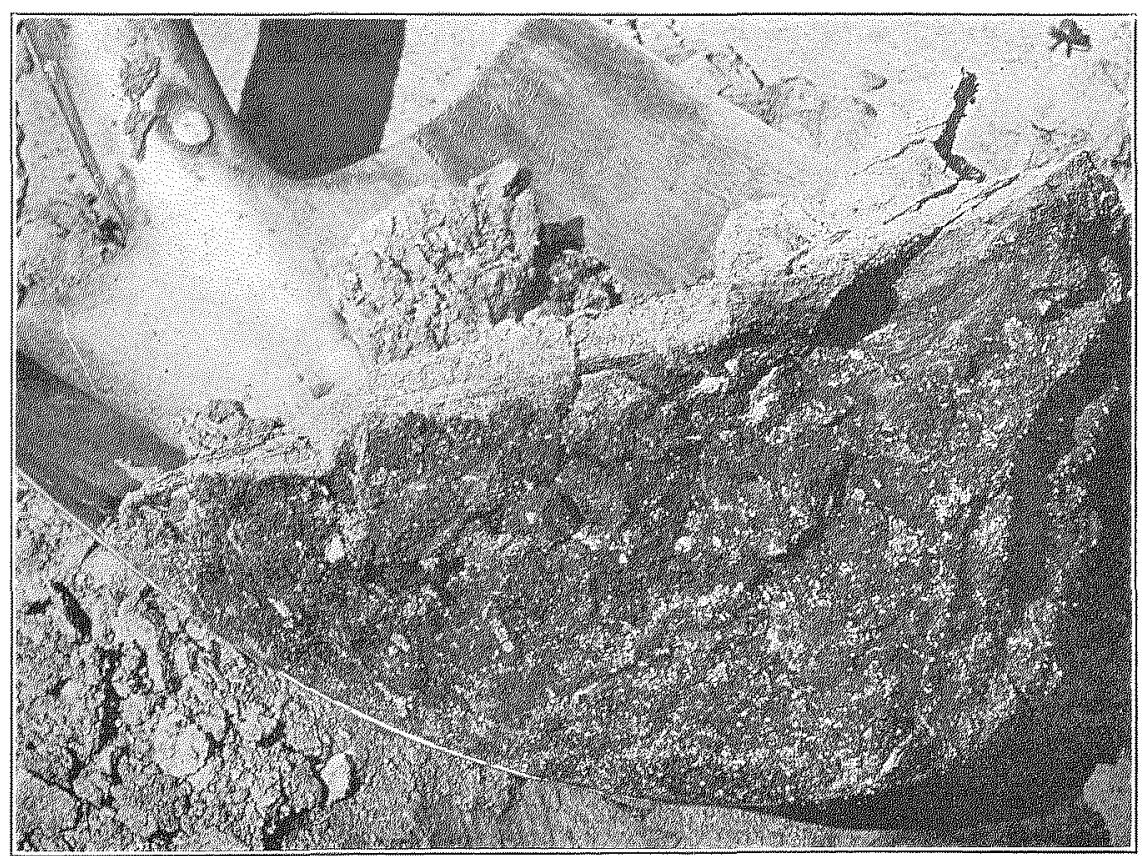

FIG. 2-SHOVELFUL OF SOIL FROM THE ABOVE PLAT. 
In Table III are given, besides the standard rotation, summary results of 28 different plans of cropping.

Some generalizations may properly be made from the results of these experiments, though the results would be very much better had land been available for as many plats for each rotation as there were years in the rotation--not only at University Farm but on three branch station farms, as designed when the experiment was begun.

All the continuously grown crops were produced at a loss, or else at from $\$ 1$ to $\$-1$ less profit than the better rotations. On most of the plats bearing continuous cropping to one crop there was a loss of organic matter during the 10-year period, 1895 to 1904, as proved by the loss both of nitrogen and carbon, as shown in Table III. In cases of all rotations where grasses, cultivated crops, and grain crops were alternated, there was an increase in organic matter in the soil as shown by increases both of nitrogen and carbon, and there were also profitable crops.

The facts shown in Table III warrant the greatest emphasis being placed on the value of vegetable matter in the soil. Practically every one of the profitable rotation schemes either maintained or increased the amount of vegetable matter in the soil as shown in the last two columns of the table, and practically every unprofitable scheme decreased the total amount of vegetable matter in the soil.

Vegetable matter, in ways not yet fully understood, gives ordinary crops a wholesome condition which they require, and enables them to secura the needed food for rapid growth.

Commercial fertilizers may very of ten be used with profit. Their use should be more widely investigated in relation to the soils of the newer States, as well as in the older. States where they are known to be profitable. Yet vegetable matter is the great fertilizer. It assists in giving to the soil at friable condition and improves the mechanical character of the subsoil. It aids the soil in retaining and giving to the crop in times of drought the needed supplies of moisture. It supplies food for soil bacteria, and partly through the agencies of these organisms and partly by the more direct action of decomposition, the soil is made wholesome and the plant food is made available to the roots of the crops.

During the millions of years in which the ordinary crop species were being developed in their wild state, they became accustomed continually to soil in which regetable matter was abundant. By upturning the fields a goodly part of the time, thus forcing the decomposition of leaves, stems, and roots and of applied vegetable matter, the farmer greatly hastens the decomposition and removal of vegetable natter from the soil of his fields. Investigrators have not been able to study out all the intricacies of the relat ion of vegetable matter to the wholesomeness of soil, or in regilld to the wholesomeness of con- 
ditions of the soil to the roots of crops, though many interesting facts have been brought out. Common experience as well as the facts so emphatically shown in Table III dictates that the cropping and fertilizing scheme must be so arranged that there will be added, at regular and frequent intervals, considerable vegetable matter which will be going through its decomposing process while the crops are growing.

To give profitable results and at the same time to maintain or increase the productivity of the soil, a system of crop rotation must provide for the maintenance of regetable matter, by the growing of griss crops, by the use of green manures, or by the application of barnyard manure, or by all of these means. (Pls. IV and V.)

In a general way, the scheme of the standard rotation (1 year cultivated crop, 1 year grain, 2 years grass, and 1 year grain) proved to be a good sequence of crops under which the soil is prepared for each crop by the preceding crop and also by the general system of the rotation. A study of Table III gives many facts regarding these 29 rotations.

TABLE IV.-Comparisons of very good and very poor cropping schemes.

\begin{tabular}{|c|c|c|c|c|c|c|}
\hline 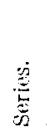 & $\stackrel{+a}{\Xi}$ & Rotation seneme. & $\begin{array}{c}\text { Net profit } \\
(+) \text { or } \\
\text { net loss } \\
(-) \\
1900-1909\end{array}$ & $\begin{array}{c}\text { Loss or } \\
\text { gain of } \\
\text { nitrogen, } \\
1895-1904 .\end{array}$ & $\begin{array}{l}\text { Loss or } \\
\text { gain of } \\
\text { carbon, } \\
1895-1904\end{array}$ & $\begin{array}{l}\text { When } \\
\text { manured. }\end{array}$ \\
\hline & & Group 1.-Very gond cropping schemes. & & Per cent. & Percent. & \multirow{11}{*}{$\begin{array}{l}1899,1904,1909 . \\
1899,1905 . \\
1900,1904,1908 . \\
1899,1904,1909\end{array}$} \\
\hline $\mathrm{IV}^{\mathrm{I}}$ & $\begin{array}{r}9 \\
10\end{array}$ & 1, wheat; 2,3 , mearlow; 4 , oats; 5 , potatoes.... & $+\$ 8.11$ & +0.008 & …....... & \\
\hline IV & 8 & 1, barley; $2,3,4$, pasturt: 5 , corn & $\begin{array}{l}+1.41 \\
+6.41\end{array}$ & $\begin{array}{l}+.011 \\
+.016\end{array}$ & +0.10 & \\
\hline IV & 5 & 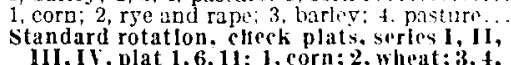 & +6.03 & +.022 & & \\
\hline & & mead ow: 5 , oats. $\ldots \ldots \ldots \ldots \ldots \ldots \ldots \ldots \ldots \ldots$ & $\begin{array}{l}+5.87 \\
+5.82\end{array}$ & +.015 & +.09 & \\
\hline III & $\frac{4}{7}$ & 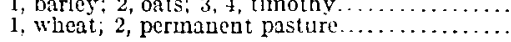 & $\begin{array}{l}+5.82 \\
+5.36\end{array}$ & +.004 & +.07 & \\
\hline & & Grovp 2.- Very poor cropping schemes. & & & & \\
\hline II & 7 & Corn in hills continuously & -1.47 & -.040 & -.54 & \\
\hline III & 9 & 1, miltet hay; 2 , clover; plow under second crop & -2.03 & +.007 & & \\
\hline $\begin{array}{l}\text { III } \\
\text { II }\end{array}$ & $\begin{array}{r}10 \\
8\end{array}$ & Rape continuously; drill; pasture oll. & $=2.41$ & $\cdots \cdots$ & +.10 & \\
\hline II & 9 & Mrangels cont inuously . ..................... & -14.35 & -.033 & -.45 & \\
\hline
\end{tabular}

In Table IV are separated out 7 rotations, including the standard rotation, which seem especially profitable, and 5 schemes of cropping which gave a positive loss. It can not be too much emphasized that in case of all the profitable rotations there is an increase in organic matter, while in four of the less profitable cropping schemes there is a loss of organic matter.

In Table $\mathrm{V}$ are presented the arerage value, cost, and profit of the individual kinds of crops. These arerages have been made up by securing all the yields of these crops where found growing in the better cropping systems as in the best two groups of rotations in Table III. 


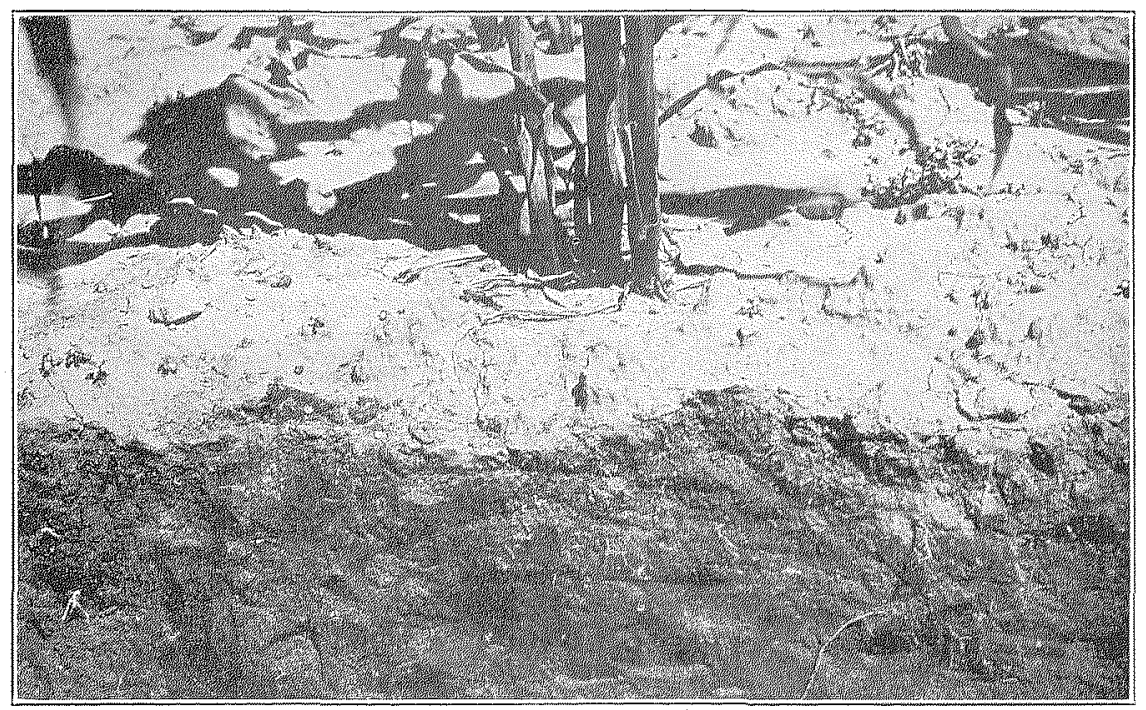

FIG. 1 -VERTICAL SECTION OF SOIL ON PLAT GROWING CORN CONTINUOUSLY.

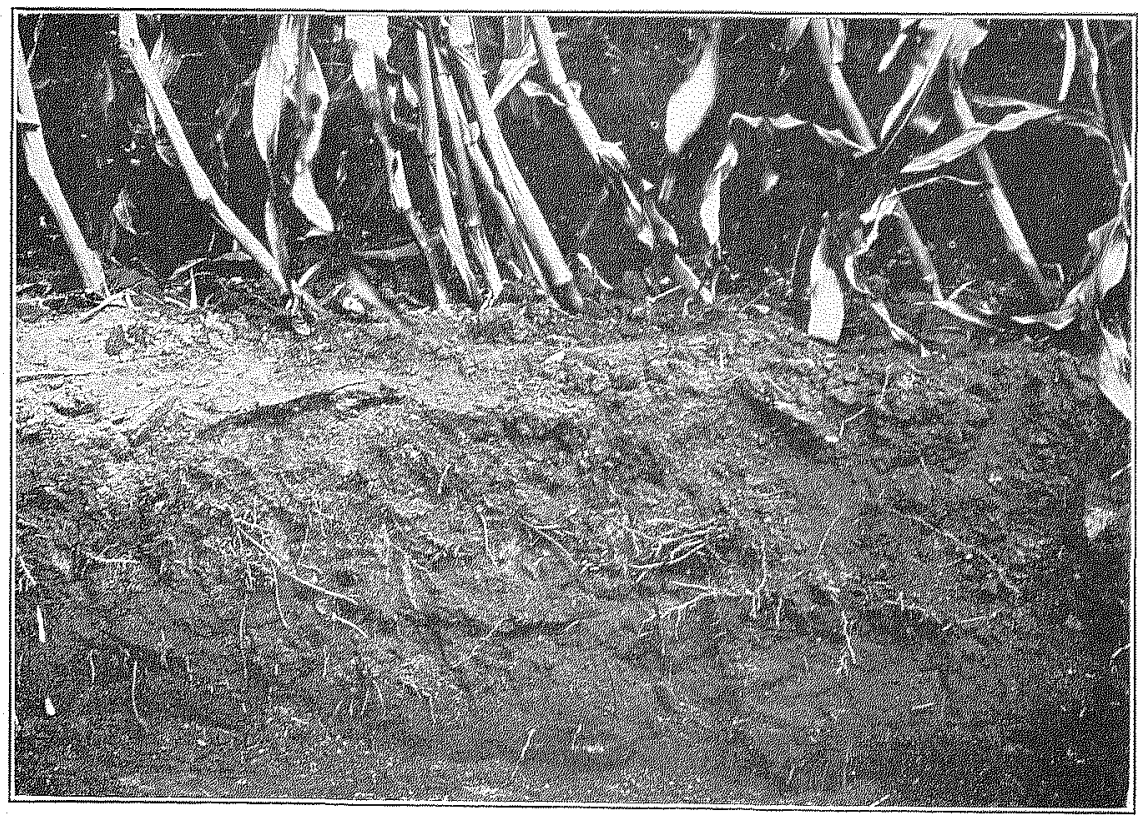

FIG. 2-VERTICAL SECTION OF SOIL ON PLAT GROWING FODDER CORN ON NEWLY BROKEN ALFALFA SOD. 


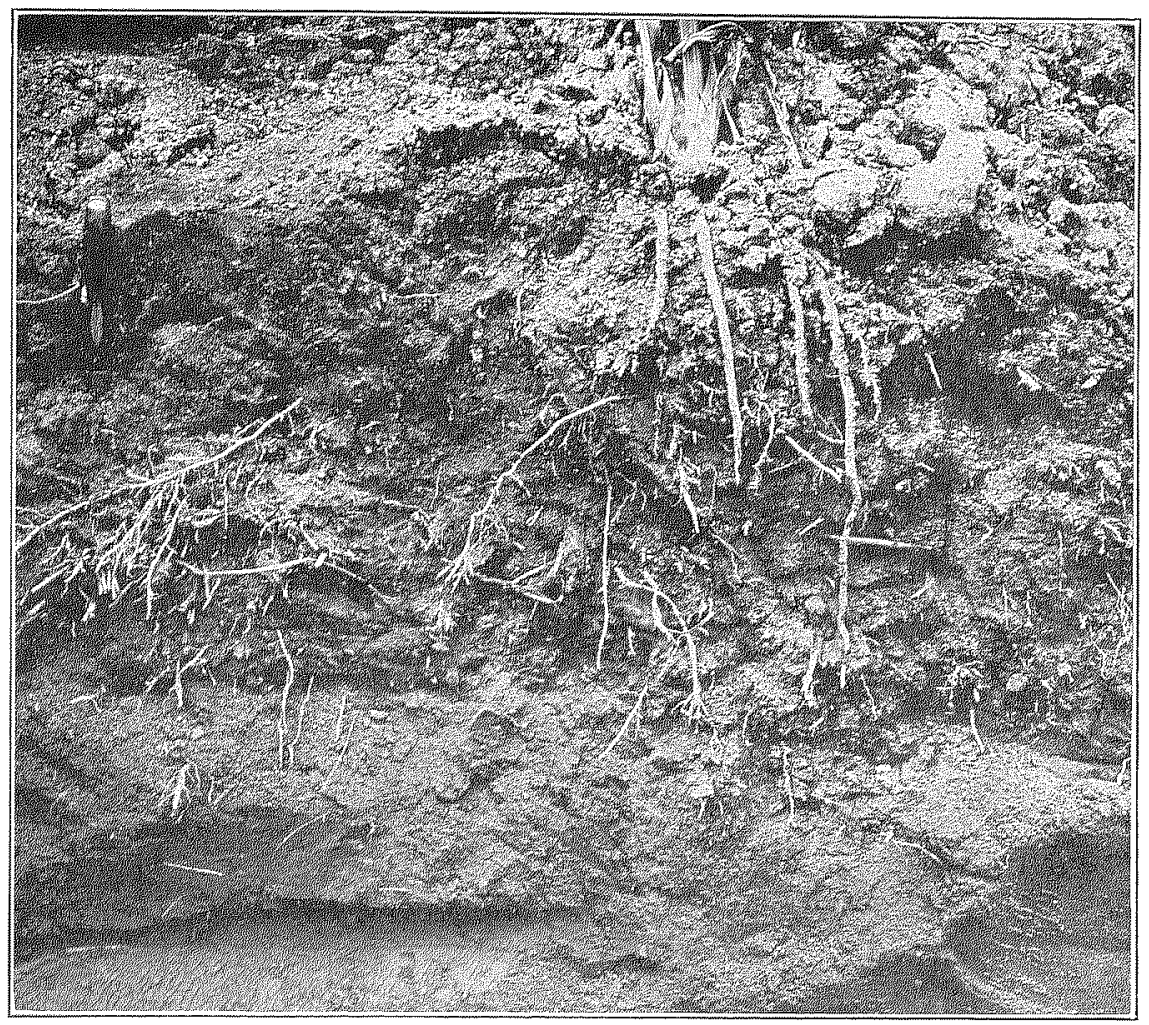

FIG. 1.-VERTICAL SECTION OF SOLL NEAR CORN PLANT GROWING ON NEWLY BROKEN ALFALFA SOD

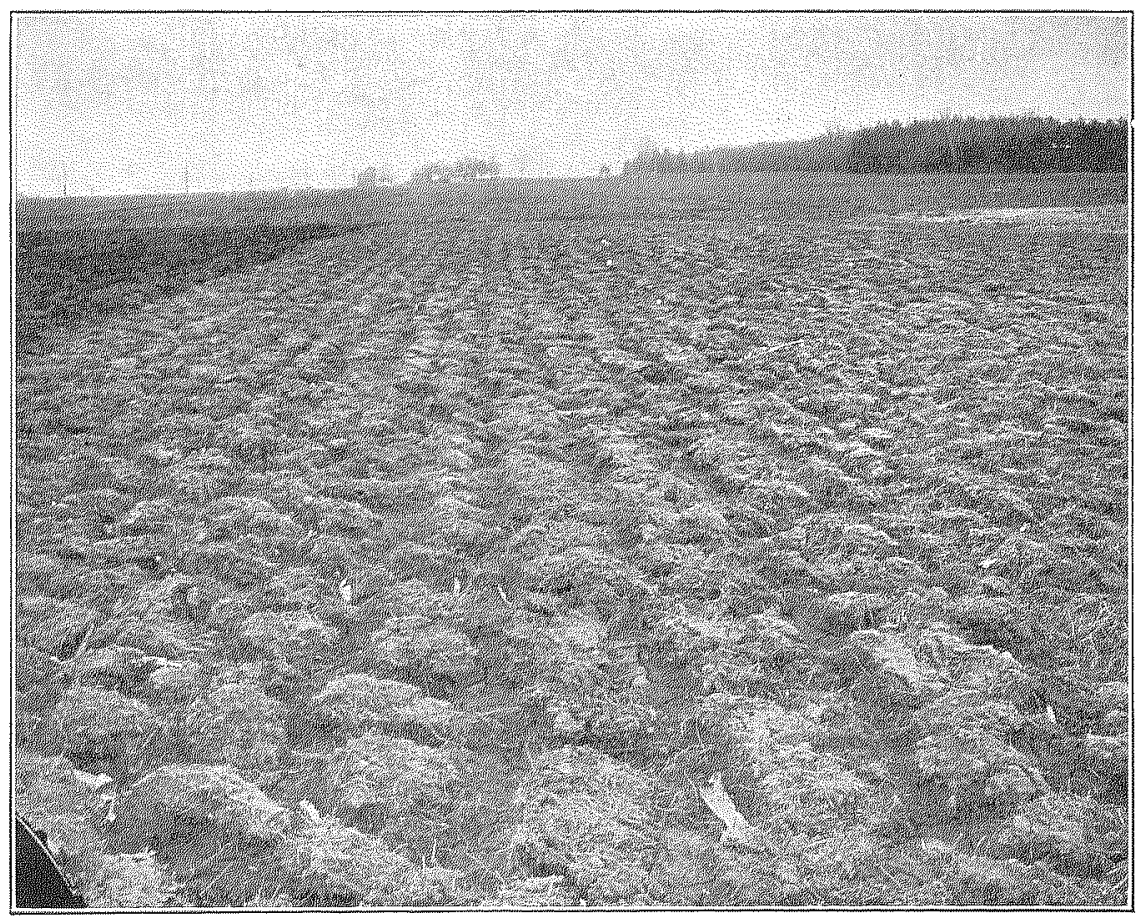

FIG. 2,-TIMOTHY SOD BACKSET AFTER PRODUCING CROP OF FLAX. 
Until exporiments in crop rotation have been much refined and have been continued over some decades it may be assumed that for the most part the several grain crops may be used interchangeably where grain comes in the rotation scheme. Serious effects have not been noted on the yields or profits of the crops with which they are grown, except in particular cases. Thus, in the standard 5-year rotation above mentioned, wheat, barley, rye, or flax may take the place of oats, though the wheat can not be so well substituted by other crops because it serves best as a crop with which to seed the timothy and clover for the two years of meadow and pasture. Potatoes, root crops, er other cultivated crops may take the place of the corn without injuriously affecting the yields of other crops in this or similar rotations. The timothy and red clover in the third and fourth years could be replaced by any leguminous and grass crop which would pay as well as the mixture of clover and timothy and would serve instead of these in adding nitrogen and humus to the soil.

The cropping scheme should be such as will lend itself to the use of such catch crops as rape among the wheat, oats, or barley, rape in corn, or rape following rye, all these to be pastured off in the autumn.

The following typical rotations show how these leading crops may be brought together in profitable sequence:

Three-year rotation: First year, cultivated crop, as corn; second year, grain; third year; clover or some annual leguminous crop. Rape can be sowed among the corn, and if, instead of clover, an annual leguminous crop is used, rape can be sowed among the wheat.

Four-year rotation: First year, cultivated crop; second and third years, clover and timothy; fourth year, grain; or, first year, cultivated crop; second year, annual leguminous crop; third and fourth years, grain, planting rape or turnips among the cultivated and grain crops, which here are sown in the spring.

Five-year rotation: First year, cultivated crop; second year, grain; third and fourth years, clover and timothy; fifth year, grain; plant rape among the corn or other cultivated crop the first and among the grain crop the fifth year. ${ }^{1}$

1 The 5-year standard rotation is profitable in Minnesota.-Table $\mathrm{V}$ shows that the rotation here used as the standard or basis for comparison will pay in $\mathbf{M}$ inneseta. The yields used are the averages of those secured on the 24 farms of which careful records have been kept in the cost-keeping investigations conducted jointly by the Minnesota Agricu'tural Experiment Statio; and the United States Department of Agriculture. The values are computed by using the average valnes of feld crops given by the Bureau of Statistics of the United States Department of Agriculture for Minnesota. The costs per acre are those determined by the investigations above mentioned.

These farms are now farmed as well as the average of the better farms. The presence of statistical routes on these farms, providing each farmer at the end of the year with a statement of $\mathrm{h}$ is results, has led to better methods.

But the yields would be even better had these crops been grown under as farorable rotation conditions as those provided in the 5-year scheme. The yield of $\$ 3.43$ per acre in addition to paying wages to the farmer himself, a rental of $\$ 3.50$ per acre, and all other expenses, is a very satisfactory return under the conditions of the broad farming in $\mathrm{Mlinnesota.} \mathrm{If} \mathrm{this} \mathrm{amount} \mathrm{is} \mathrm{reduced} \mathrm{by} \$ 1.43$ per acre, nearly half, the average farmer can still make 82 per acre above rent, ull lishor, and all other expenses. The State can easily average this income, and the better farmers, especially those with land of average productivity, can exceed it. 
TABLE V.-Net profit from standard rotation, based on average Minnesota yields.

\begin{tabular}{|c|c|c|c|}
\hline Crop. & Yield. & Value. & Cost. \\
\hline 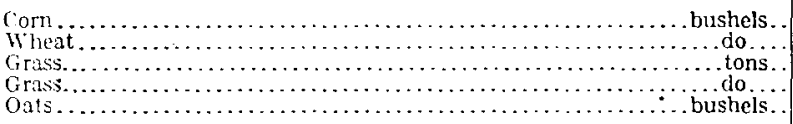 & $\begin{array}{r}35.5 \\
15.0 \\
1.8 \\
1.8 \\
31.3\end{array}$ & $\begin{array}{r}\$ 12.25 \\
10.50 \\
9.72 \\
9.72 \\
8.45\end{array}$ & $\begin{array}{r}\$ 14.28 \\
9.86 \\
9.19 \\
6.19 \\
10.69\end{array}$ \\
\hline 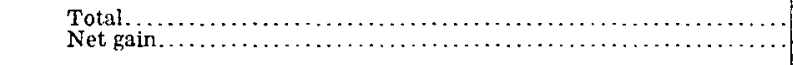 & $\ldots \ldots \ldots$ & 50.64 & $\begin{array}{r}47.21 \\
3.43\end{array}$ \\
\hline
\end{tabular}

Six-year rotation: First year, cultivated crop; second year, grain crop; third, fourth, and fifth years, grass; sixth year, grain; or, furst year, cultivated crop; second year, grain crops; third and fourth years, clover and timothy; fifth and sixth years, grain; or, first year, cultivated crop; second year, grain; third and fourth years, clover and timothy; fifth year, cultivated crop; sixth year, grain, planting catch crops in the grain and corn.

Seven-year rotation: First year, cultivated crop; second year, grain crop; third, fourth, and fifth years, timothy and clover; sixth and seventh years, grain; or, first year, cultivated crop; second year, grain crop; third and fourth years, timothy and clover; fifth year, cultivated crop; sixth and seventh years, grain crops, planting catch crops wherever practicable.

Many other similar rotation combinations of these and other standard crops may be devised, and the one should be chosen which best fits the number and arrangement of fields practicable on the given farm and which so combines the best paying crops in a sequence under rotation which will give superior conditions for each and every crop and will also fit into the use of crops for live stock, such as can be economically produced with the available labor, machinery, and equipment.

The matter of using one or more rotation schemes for individual farms is amply illustrated in figures 12 to 17 (Spring Lawn Farm) and also in figures 18 to 57 (student plans).

The facts above stated, together with the facts presented in Table $V$, giving the value per acre, cost per acre, and the net profit per acre for the respective crops, will greatly assist the farmer in deciding on rotations and on an entire farm cropping scheme, combined with livestock production, and on the division of his fields for one, two, or more rotation systems.

\section{COMPARISON OF CROPPING SYSTEMS TESTED.}

The results from the 44 plat tests begun in 1894 on University Farm, as shown in figure 7, during the decade 1895 to 1904 , inclusive, with interpretations made possible by the exhaustive cost-keeping investigations, carried out during the same period on more than a score of 
practical Minnesota furms in typical regions of the State, give facts of importance in connection with the reorganization of farms. Thęse results are such that they may well serve as an epochal mark in the organization and arrangement of Minnesota's farms, which yield profits far below those warranted by the soil and climatic conditions.

The results here reported, as of the 5-year control rotation on the 12 check plats, of $\$ 5.87$ net profit per acre in addition to paying a rental of $\$ 3.50$ per acre, as well as labor and all other cost, is, in itself, an inspiration. This simple, practical rotation plan is as follows: First year (8 tons barnyard manure per acre), corn; second year, wheat; third year, clover and timothy meadow; fourth year, clover and timothy pasture; fifth year, oats.

But even more inspiring is the comparison between the crops of the various cropping schemes given in Table III, and especially between the crops of the cropping schemes shown in Table IV. If the farmers of Minnesota would adopt and properly carry out some of the best of the rotations shown in Table IV their yields would be increased by $\$ 2$ or more per acre above what they now secure from the often unsystematic cropping schemes irregularly carried out.

And these experiments demonstrate further, declucting a good percentage for the firrorable conditions under which the crops were grown on the tenth-acre plats at Lnirersity Farm, and also on the half-acre plats beside them. that Minnesota fields may be made to double and treble the net profits per acre now secured.

A careful examination of notes under figure 7 will show that these various rotations were carried out in a manner entirely normal to the average farm in the State. There was no unusual means of forcing and the soil on which these crops were grown is naturally only the a verage of the soils of the state.

While under the plan of this experment only one plat was for the most part devoted to each cropping scheme, and the crops in that scheme are thus not dist ributcd through the different seasons because of lack of land, yet the average of the sereral profitable rotations may properly be compared with the average of the several less profitable rotitions. The differences in the yields thus secured are so pronounced that it may be positively stated that under the general plin of the better rotations the net profit per acre of Minnesota farms may be greatly increased. Thus the average profit from the crops of the seven rotation schemes yielding more than $\$ 5.87$, of the control rotation, and of the six schemes which yielded over s.5 per acre, after paying $\$ 3.50$ rent per acre, is $\$ 6.02$, or 15 cents more than the net profit of the standard rotation.

At the other extreme, the five schemes of cropping which were produced at a loss, averaged, alter paying $\$ 3.50$ rent, $\$ 4.72$ less than the cost, or $\$ 10.59$ less than the control rotation. 
Thus when the individuality of the plats are merged into averages, the broad comparison most emphatically demonstrates the profit of some rotations as compared with others.

There seems no reason for minimizing the full force of these figures in the business of crop production in Minnesota. In 1899 according to the Twelfth Census, Minnesota farmers produced on $18,412,585$ acres of improved land, farm products worth $\$ 161,217,304$, or $\$ \$ .74$ per acre. Prices are now higher and the acreage of improved farm lands has been materially increased. For use in illustrating this subject we may assume that Minnesota has 20,000,000 acres of improved land, yielding an average of $\$ 10$ per acre or $\$ 200,000,000$ worth of live stock and farm products. The Thirteenth Census will probably show this to be too low, but the round numbers will make calculations easy. It is fair to assume that the farmers of the State do not use cropping schemes which average better than those in the third and fourth groups in Table III, in which, after paying $\$ 3.50$ rent, the net income on the plats at University Farm was from $\$ 1.42$ to $\$ 5$ per acre. The ten cropping schemes in these two groups rielded on Lniversity Farm, an average of $\$ 3.51$ per acre after paying rent. On the other hand, the 14 cropping schemes in the first two groups in Table III, yielded an average of $\$ 6.02$ after paying rent. Taking into account the fact in either case that the better care of the fields on University Farm was in part responsible for the yields giren, it may still in all fiimess be estimated that Minnesota farmers could increase their yields at least $\$ 2$ an acre simply by adopting and strictly adhering to such rotation schemes as those in the first group in Table IV.

The added income from $20,000,000$ acres of improved land at $\$ 2$ yer acre would be $\$ 40,000,000$, or an average of $\$ 200$ on each of 200,000 farms. If the investigations by the United States Department of A rriculturo and the State experiment stations, the instruction in asricultural high schools and agricultural colloges, in consolidated raral schools, district rural schools and farmer's' institutes, supplemented by publications, both public and private, and by other means promoting good farm management, would induce the farmers to reorganize their farms properly and would result in this increased income at a cost in the State of national and State expenditures of a million dollar's ammually, the surplus would be $\$ 39,000,000$. If $\$ 9,000,000$ of this were required to rearrange the fields, move and build fences, do the field work in a botter way than is now done, and buy and care for better seed, the net surplus to the people would still be $\$ 30,000,000$ and, in the large view, the figures would reach this sum, leaving a net profit of $\$ 150$ per farm. Speaking broadly and with averages, out of the $\$ 150$ increased earnings each furmer should be able to use $\$ 50$ in increasing the value of buildings, implements, 
machinery, and live stock, which averaged in 1900 for the State about $\$ 1,500$ per farm, raising the average in 10 years to $\$ 2,000$ per farm. The other $\$ 100$ is needed by the average farm family to provide leisure and facilities for better education and to develop country life more rapidly.

An average of $\$ 100$ more annually, devoted to better food, better schools, better home education and the social development of Minnesota's farm boys and girls would so react as to increase even more largely the income and splendid country life springing from Minnesota's land. Still another $\$ 150$ per farm could bo added to tho incomes by developing better varieties of crops and better breeds of live stock; and it may be that still another $\$ 150$ could be added by the use of fertilizers costing less than half that amount.

Several of these rotation schemes are worthy of special mention. The 5-yoar control rotation on the 12 check plats, 1,$6 ;$ and 11 of each of the series I, II, III, and IV, with which the other rotations were compared is of peculiar interest. This rotation is: First year (8 tons manure per acre). corn; second year, wheat; third year, timothy and clover meatow; fourth year, timothy and clover pasture; fifth year, oats. The average cash income per acre per year for this rotation for the 10 years 1900 to 1909 on these 12 plats was $\$ 15.89$. The average cost per acre to produce the crops, including a rental charge of $\$ 3.50$ per acre, cost of labor, machinery, and all other expenses was $\$ 10.02$, leaving an average net profit of $\$ 5.87$ per acre.

Wheat continuously: plat 2, series III, yielded a gross product worth $\$ 13.08$ at a cost of $\$ 9.94$, leaving an average net profit of $\$ 3.14$, or $\$ 2.73$ less than was produced by the control rotation.

Wheat continuously with 6 pounds red clover seeded with the wheat. plat 3, series III, and the crop of clover plowed under in the fall with the wheat stubble, for the same years yielded crops worth $\$ 14.88$ at a cost per acre, including cost of the clover seed. of $\$ 10.90$, leaving a net profit of $\$ 3.98$ or $\$ 0.84$ more than the plat growing wheat continuously without clover, or $\$ 1.89$ less than the 5-year control rotation.

It is worthy of note that the plats which grew wheat continuously finally becamo infested with wild oats, probably from the droppings of horses working on them, while in the plats in the standard rotation, and in the other rotations in which cultivated crops, grain crops, and grass crops alternated, the wild oats did not even get a foothold.

\section{CORN GROWN CONTINUOUSLY.}

The very poor results on plat $\tau$, series II, Table III, planted to corn continuously, may be a surprise to many. It is generally believed that corn has no harmful effect upon the soil. It is well known 
that usually after a crop of corn a larger yield of grain is secured. It will be observed that this plat gives poorer returns than plat 2, series III, on which wheat has grown continuously. This is contrary to what is generally expected since wheat has the reputation of being hard on the soil while corn is believed to be beneficial. The decreased yield may of course be partly due to increase of such insect. encmies as root worms and the corn root-aplis which would have good opportunity to multiply under these conditions.

The frequent cultivation given the corn maintains during a large portion of the year an effective surface mulch which does very much In allowing the water from rainfall to percolate into the soil and in (conserving it by checking eraporation. The cultivation, by aeratingr the soil and conserving the moisture, stimulates decomposition. thus effectively maintaining the conditions favorable for bacterial and chemical activity.

The larger yiclds of grain usually obtained following a crop of corn show that this crop improves the soil for other crops; but when the stalks are removed the stubble and corn roots ret urn but very lit tle recretable matter to the soil, and when com is grown year after year on the same field the regetable matter in the soil is rapidly decompoed and depleted, doubtless more rapidly than is the case with continuous wheat growing, mainly because the cultivation of the com stimulates the decomposition, while in the wheat field the decomposition is less rapid.

Though com grown continuously on this plat mado the soil unproductive for com yet a study of the yields of other crops following corn in rotation on other plats show it to be a raluable crop in a rotation system where the regetable matter is kept up by manure and by grass crops. The growing of corn, as with grass, is also condurive to the keeping of live stock, which results in more manure wadd to the fields. There are few of the common field crops which cin be more profitably grown on a portion of the averagre Minnesota farm than corn, when manure or grass crops, or both, are used to kecp up the supply of regetable matter.

MODEI, ROTATION.

In 1 sos the field containing the 44 rotation plats just discussed wis extended to the west 20 rods and 12 more plats, 3 plats in each scries, were added. Firure 8 gives the key map showing the rotations of crops of these plats.

As shown in figure 8 , the five half-ace plats, $A, E, B, F$, and G. connected with arrows, were planted to the same standard rutation used on the check plats in the 44 plits on the east end of this same field, viz, first year, corn; second jear, wheat; third year, meadow; fourth year, pasture; fifth year, oats. On the three plats 
$\mathrm{H}, \mathrm{D}$, and $\mathrm{C}$, connected with arrows, was planted the following rotation: First year, corn; second year, wheat; third year, clover. On the two plats $I$ and $K$, connected with arrows, wheat and annual pasture were grown in a two-year rotation and on the other two plats, $L$ and $M$, wheat and mangels were grown in a two-year rotation. In Tables VI and VII are presented the rields, cash value, and annual cost, also the net profit for the 10-year period, 1901 to 1910 , on the respective plats in each of these two rotations.

By providing as many plats as there are years in the rotation each crop is grown each year, thus largely eliminating seasonal differences and making one rotation more nearly comparable with another. Besides, the individualities of the plats are merged into averages. The average cash value of the crops grown on the five-year rotation is $\$ 16.71$; the average value of the three-year rotation is $\$ 14.49$. It is worthy of note that the yield of the five-year rotation on the five plats is nearly the same as the average of this same rotation grown on the twolve check plats on the east part of this same field.

TABLE VI.-Yields and cash value of crops grown on each of the five 5-year rotation plats.

SERIES I, PLAT $13(A)$.

\begin{tabular}{|c|c|c|c|c|}
\hline Tear? & Cтор. & Yield. & $\begin{array}{c}\text { Cash } \\
\text { ralue. }\end{array}$ & Cost. \\
\hline $\begin{array}{l}1907 \\
1902 \\
1903 \\
1904 \\
1905 \\
1906 \\
1907 \\
1908 \\
1909 \\
1910\end{array}$ & 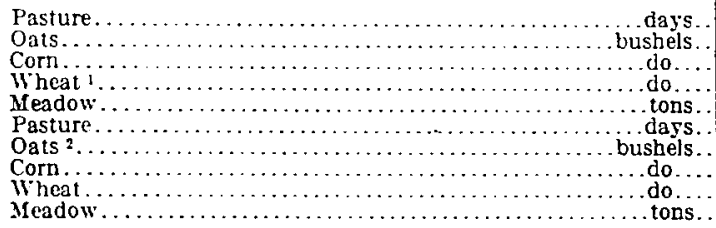 & $\begin{array}{r}57.30 \\
85.00 \\
85.30 \\
32.00 \\
5.83 \\
132.00 \\
44.60 \\
53.60 \\
\text { 35. } 50 \\
1.06\end{array}$ & $\begin{array}{r}\$ 2.05 \\
23.21 \\
29.51 \\
22.53 \\
31.72 \\
4.75 \\
12.18 \\
18.55 \\
25.01 \\
5.77\end{array}$ & $\begin{array}{r}54.47 \\
11.71 \\
15.96 \\
9.59 \\
7.18 \\
4.47 \\
10.94 \\
18.08 \\
9.67 \\
7.18\end{array}$ \\
\hline & $\begin{array}{l}\text { Total } \ldots \ldots \ldots \ldots \ldots \ldots \ldots \\
\text { Plus manure for corn, } 1903 \text { and } 1908 \ldots \ldots \ldots \ldots \ldots \ldots\end{array}$ & & $\begin{array}{r}175.28 \\
17.53\end{array}$ & $\begin{array}{r}99.25 \\
5.70 \\
10.50\end{array}$ \\
\hline
\end{tabular}

SERIES I, PLAT 14 (B).

\begin{tabular}{|c|c|c|c|c|}
\hline $\begin{array}{l}1901 \\
1902 \\
1903 \\
1904 \\
1905 \\
1906 \\
1907 \\
1906 \\
1909 \\
1910\end{array}$ & 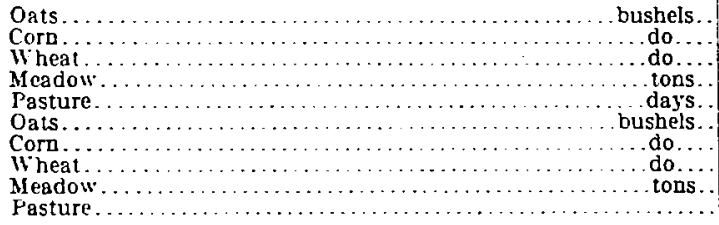 & $\begin{array}{r}62.50 \\
78.60 \\
30.80 \\
5.77 \\
217.60 \\
72.00 \\
52.20 \\
25.00 \\
.80\end{array}$ & $\begin{array}{r}817.06 \\
27.20 \\
21.68 \\
31.39 \\
7.78 \\
19.66 \\
18.06 \\
17.60 \\
4.35\end{array}$ & $\begin{array}{r}811.28 \\
15.35 \\
9.56 \\
7.18 \\
4.47 \\
11.46 \\
12.95 \\
9.43 \\
7.18 \\
\text {...... }\end{array}$ \\
\hline & $\begin{array}{l}\text { Total . . . . } \\
\text { Plus manure for corn, } 1902 \text { and } 190 \bar{\ldots} \\
\text { Average, } 9 \text { ycars (net profit } \$ 5.80) \ldots\end{array}$ & & $\begin{array}{l}164.78 \\
18.31\end{array}$ & $\begin{array}{r}88.86 \\
5.70 \\
10.51\end{array}$ \\
\hline
\end{tabular}

1 Somn on disked corn land.

2 Breaking \$1.67; disking $\$ 0.60$. 
TABLE VI.- Yields and cash value of crops grown on each of the five 5-year rotation plats-Continued.

SERIES II, PLAT 13 (D).

\begin{tabular}{|c|c|c|c|c|}
\hline Year. & Crop. & Yield. & $\begin{array}{c}\text { Casl } \\
\text { value. }\end{array}$ & Cost. \\
\hline $1: 01$ & ...bushels. & 42.80 & \$14.81 & $\$ 12.10$ \\
\hline 1,902 & Wheat & 25.10 & 17 & 9.43 \\
\hline $1: 03$ & Meadow. & & 29. & 7.19 \\
\hline 1004 & Pasturo... & $15+50$ & 5.52 & 4.47 \\
\hline 1905 & Oats. & 84.25 & 23.00 & 11. 69 \\
\hline 1006 & Corn & 60.50 & 20.93 & 13.7 \\
\hline $1: 407$ & Wheat. & 23.90 & 16. & 9.40 \\
\hline $1: 0 \mathrm{~S}$ & Mendow. & 5.01 & 27.25 & 7. 15 \\
\hline 1909 & 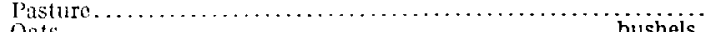 & \multirow{5}{*}{45.00} & in 0 & 110 \\
\hline \multirow[t]{4}{*}{1910} & 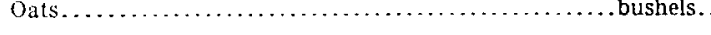 & & 12. 29 & 10.95 \\
\hline & Total. & & 165.22 & S6. 11 \\
\hline & Plus mavure for corn, 1901 and 1900 . & & 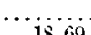 & 5. 70 \\
\hline & & & 15.69 & 10.20 \\
\hline
\end{tabular}

SERIES II, PLIT 14 (C).

\begin{tabular}{|c|c|c|c|c|}
\hline 1,01 & Wheat . . . . . . . . . . . . . . . . . . . . . . . . . bushels. & 15.20 & $\$ 10.70$ & $\$ 9.20$ \\
\hline $1 \div 02$ & 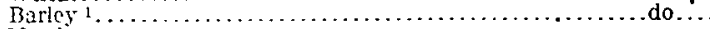 & 23.50 & 11.03 & 9.54 \\
\hline 1,03 & Meadow..... & & & \\
\hline $1: 0.4$ & ........... bushols. & 58.70 & 16. 03 & 11. 21 \\
\hline 1005 & 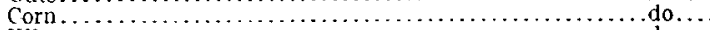 & 64.40 & 22.28 & 14. 06 \\
\hline $1: 106$ & Wheat.. & 22.60 & 15.91 & 9.37 \\
\hline $1: 107$ & 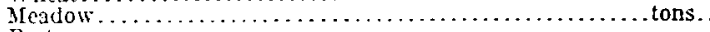 & 1. it & 0.20 & 7.18 \\
\hline $1: 08$ & 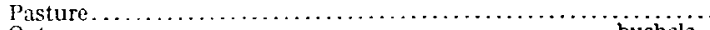 & & & \\
\hline $1: 09$ & 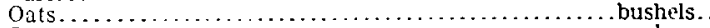 & 75.80 & 20. 69 & 11.53 \\
\hline \multirow[t]{4}{*}{ 1! 10} & 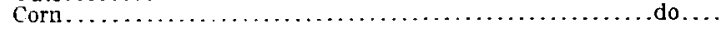 & 36.94 & 12. 78 . & 11.56 \\
\hline & Total.... & & 115.62 & 83. 65 \\
\hline & Plus manure for corn. 1905 and $1910 \ldots$ & $\cdots$ & $\because ; \because z$ & \\
\hline & Average, s years (net profit 33.28 ). . . & & 14.45 & 11.17 \\
\hline
\end{tabular}

SERIES III, PLAT 14 (E).

\begin{tabular}{|c|c|c|c|c|}
\hline & & & & \\
\hline 1901 & Meadow . . . . . . . . . . . . . . & 2.30 & $\$ 12.51$ & 87.18 \\
\hline 1,02 & Pasture . . . . . . . . . . . . . . . & 1.95 & 10.61 & 4. 47 \\
\hline 1903 & 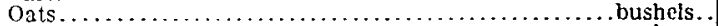 & 61.70 & 16.84 & 11.26 \\
\hline 1904 & 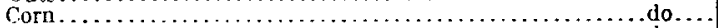 & 37.10 & 12.84 & 11.58 \\
\hline 1005 & Wheat. . . . . . . . . & 30.90 & 21. 75 & 9.57 \\
\hline$[! 004$ & 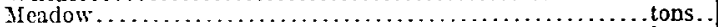 & 2.18 & 11.86 & 7. 18 \\
\hline 1007 & 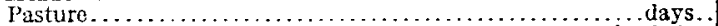 & 96.00 & 3.50 & 4. 47 \\
\hline 1908 & $\ldots \ldots \ldots \ldots \ldots \ldots$ bushels. & 42.20 . & 11.52 & 10.89 \\
\hline $1: 09$ & $\ldots \ldots \ldots \ldots$ do & $7 \pm .72$ & 25.85 & 15.00 \\
\hline \multirow[t]{4}{*}{1010} & 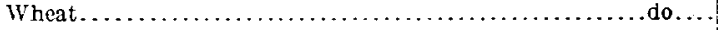 & 25.36 & 17.8 .5 & 9.44 \\
\hline & Total. & & 145.13 & 91.04 \\
\hline & Plus manure for corn, 1904 and 1909. & & & 5.70 \\
\hline & A verage, 10 years (net profit 34.84 )... & & .14 .51 & 9.67 \\
\hline
\end{tabular}

I Substituted for grass which did not catch.

TABLE VII.-Yields and cash values of crops grown on the three-year rotation for ten years, 1901-1910.

SERIES III, PLAT 13.

\begin{tabular}{|c|c|c|c|c|}
\hline Yoar. & Crop. & Yield. & $\begin{array}{l}\text { Cash } \\
\text { value. }\end{array}$ & Cost. \\
\hline 1901 & $\ldots \ldots \ldots \ldots \ldots \ldots$ tons. & 1.58 & $\$ 8.60$ & $\$ 8.08$ \\
\hline 1302 & 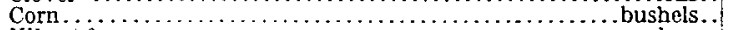 & 62.50 & 21. 03 & 13.89 \\
\hline 1003 & ........ do... & 24.40 & 17. 1 s & 9.42 \\
\hline 1401 & ...... tons. & 4.20 & 23.17 & 8. 0 s \\
\hline 1005 & ... busbels.. & 64.10 & 22.18 & 14. 04 \\
\hline 11706 & Wheat. & 13.30 & 9.30 & 9.10 \\
\hline 1,107 & ....tons. . & 1.25 & 6.80 & 8.08 \\
\hline 1908 & ..... . bushels. . & 33.60 & 13. 36 & 11. 71 \\
\hline 1909 & $\ldots \ldots \ldots \ldots \ldots \ldots \ldots \ldots \ldots$ & 20.33 & 1.1. 31 & 0.32 \\
\hline \multirow[t]{2}{*}{1910} & $\ldots \ldots \ldots \ldots \ldots \ldots \ldots \ldots \ldots \ldots \ldots . . \ldots \ldots$ tons. & 0.62 & 3.37 & 8.03 \\
\hline & Total ............. & & $\begin{array}{r}134.96 \\
14.00\end{array}$ & $\begin{array}{r}99.86 \\
9.99\end{array}$ \\
\hline
\end{tabular}

1 Eight pounds seed at 15 cents.

: Land disked, not plowed. 
TABLE VII.-Yields and cash values of crops grown on the three-year rotation for ten years, 1901-1910-Continued.

SERIES IV, PLAT 13.

\begin{tabular}{|c|c|c|c|c|}
\hline Year. & Ćop. & Yield. & $\begin{array}{l}\text { Cash } \\
\text { value. }\end{array}$ & Cost. \\
\hline 1901 & 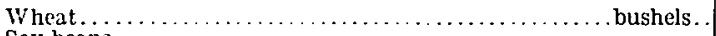 & 13. 60 & $\$ 9.57$ & $\$ 9.17$ \\
\hline 1902 & 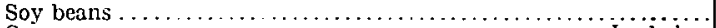 & & & an \\
\hline 1903 & $\ldots \ldots \ldots \ldots \ldots \ldots$ bushels. . & 54. 70 & 18.93 & 13. 18 \\
\hline 1904 & 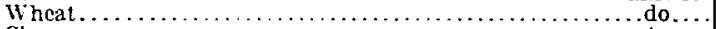 & 27. 30 & 19. 22 & 9.48 \\
\hline 1905 & 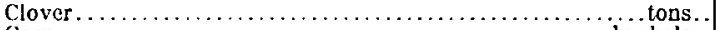 & 4.86 & 26. 44 & 8. 08 \\
\hline 1906 & 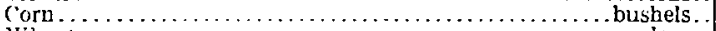 & 36. 10 & 12. 49 & 11. 49 \\
\hline 1907 & 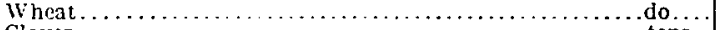 & 19. 10 & 13.45 & 9.29 \\
\hline 1908 & 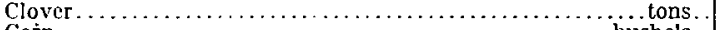 & 3.24 & 17. 63 & 8.08 \\
\hline 1909 & bushels. . & 39.17 & 13.55 & 11. 77 \\
\hline \multirow[t]{3}{*}{1910} & 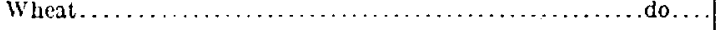 & 20.93 & 14. 73 & 9.34 \\
\hline & Total ................. & & 146.01 & 89.88 \\
\hline & A verage, 9 years (net profit $\$ 6.23$ ).. & & 10.22 & 9.99 \\
\hline
\end{tabular}

SERIES IV, PLAT 14.

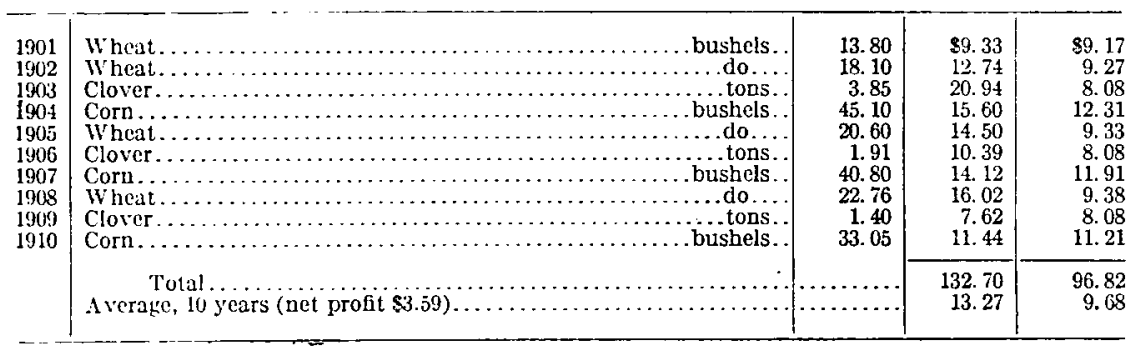

In Table VIII the average cost of production of the five crops in the standard rotation is compared with the production of wheat grown continuously.

TABLE VIII.--Cost of cropping under standard rotation and continuous wheat cropping.

Cropping under 5-year rotation system:

Cost

per acre.

Manuring, 8 tons per acre once in 5 years................... $\$ 2.50$

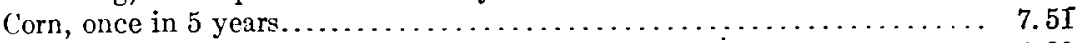

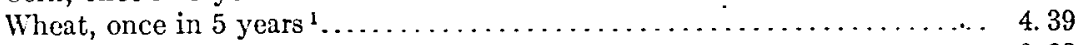

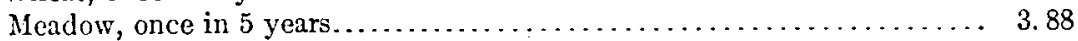

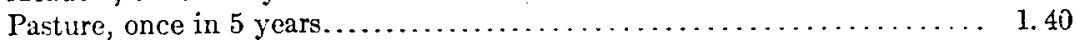

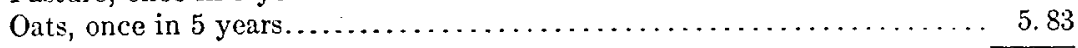

Total cost, except rent, per acre for 5 years...............

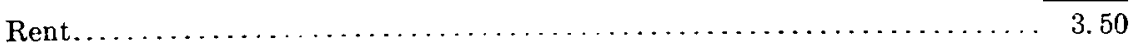

Average annual cost per acre.............................. 5. 10

Total cost per acre............................... 8.60

Cropping to wheat continuously:

Average annual cost, except rent, per acre.......................... 5.12

Total cost per acre................................

Note.-The above, figures showing the cost of the two systems of cropping were taken from the United States Department of Agriculture, Bureau of Statistics Bul-

1 Seventy-three cents is deducted from cost of growing wheat on fall plowing, as wheat in this rotation is grown on dished corn land.

$16029^{\circ}-$ Bull. $236-12-3$ 
letin No. 73, and Minnesota Agricultural Experiment Station Bulletin No. 117 on the cost of producing farm products. The figures showing the average for the State were used. To get the cost of meadows and pastures it was necessary to establish a price for grass seed. The only figures available were those given in the United States Department of Agriculture Yearbook, showing the wholesale prices in Chicago. These prices were for the 10 years 1897-1906, inclusive, 3.17 cents per pound for timothy and 7.7 cents per pound for red clover. As prices for grass seed are at present high, an arbitrary price of 12 cents for clover and $3 \frac{1}{2}$ cents for timothy was used. The seeding used on those plats was 6 pounds of clover and 8 pounds of timothy per acre, worth at 12 cents and 3 ! cents, respectively, $\$ 1$. This cost of grass seed is charged equally against the meadow and pasture. The only cost against the pasture is 50 cents for seed and 90 cents-for fencing.

Since the average value of the crop from this 5 -yoar rotation, as shown in Table III, is $\$ 2.73$ more than the value of the whoat crop,
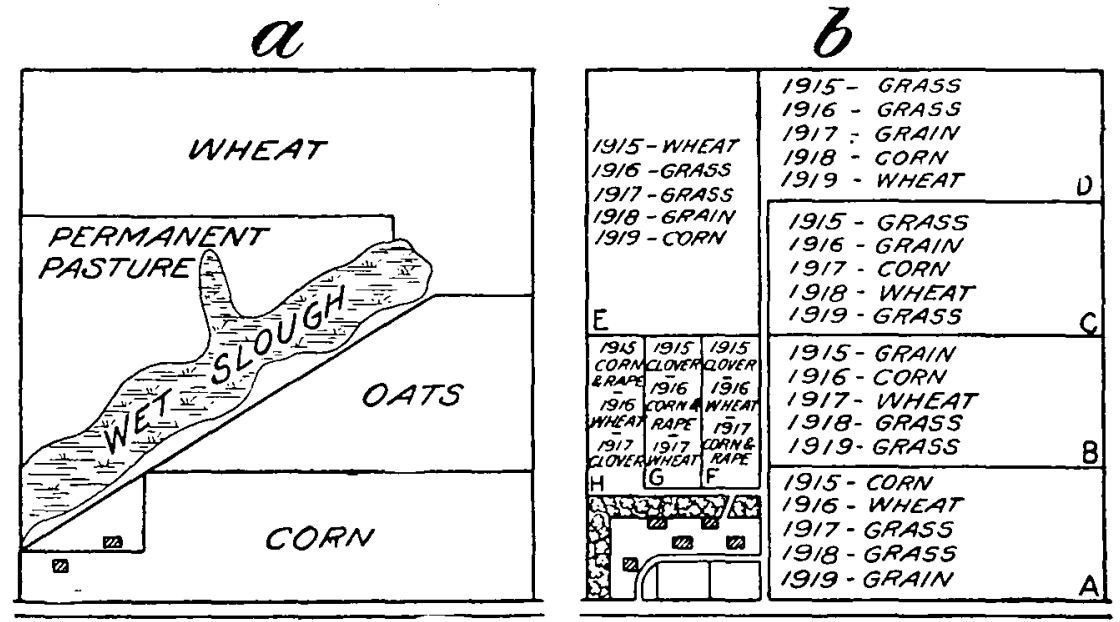

FIG. 9.-a, 160-acre Dakota County farm as cropped in 1906. The whole farm is tillable, but is poorly organized. The average distance from the farmstead to the fields is 70 rods, and the total amount of inside fencing requbed to fence all of the fields is 892 rods. $b$, Same farm as in $a$, but reorganized for a 5 -year rotation. The average distance from the farmstead to the fields is now but 24 rods, and the total amount of fencing required for inside lences is only 640 rols. The crops are each year to be changed by rotation so that cach field will produce each crop once in five years.

we have here another proof that the figures given above are correct, showing that an efficient system of crop rotation would increase the income of land which grows wheat continuously by at least $\$ 2$ per acre.

\section{THE 5-YEAR ROTATION APPLIED TO FARM CONDITIONS.}

The maps in figure 9 illustrate how this 5-year rotation actually applies to a 160 -acre farm. "The farm chosen is a 160 -acre farm in Dakota County; Minn., all of which is tillable. The original arrangement of fields and crops in 1906 is shown in $a$ and the reorganization plan in $b$. 
The maps in figure 10 show the original $(a)$ and the revised plan (b) of another farm. Here $b$ provides for five 30-acre fieids for the rotation. The crops for but one year are shown, but the crops are to be changed each year on each field the same as has boen carried out on the rotation plats. Corn is followed by grain and grass seed, grain by meadow, meadow by pasture, and pasture by oats; then again, starting with corn, the rotation cycle of five years is repeated indefinitely.

The foregoing maps show very plainly how a farm that is all tillable may be conveniently divided and cropped. It will be observed by comparing the two plans that there are fower fields and they are of better form to work, as the farm is roorganized, than under tho former plan. Very little more fencing is used to bring all the fields under fence in the rotation plan than for permanent pasture under tho former plan. This cost will be offset many times by the increased
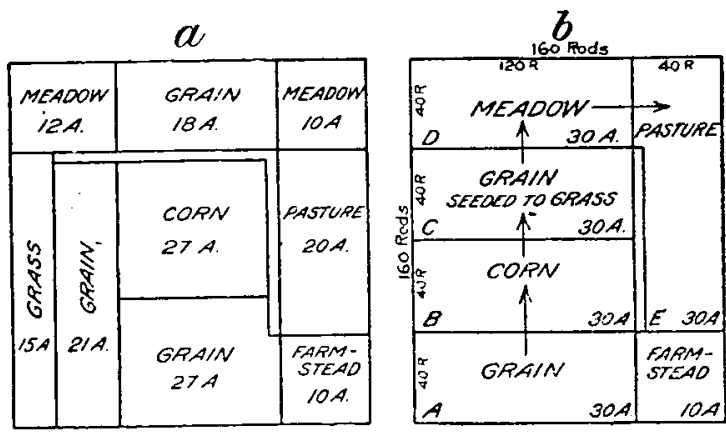

FIG. 10. $-a$, Another unor anizal farm; $b$, same farm reorganized.

yields of pasturago from land that has been in hay but ono year over old pastures, under the conditions in Minnesota, by the increased yields of grain or corn on the pasture sod over yields obtained on old grain fields, and by the pasture secured in the stubble fields in which rape, turnips, and other catch crops are grown.

YIELDS OF CORN, WHEAT, AND HAY UNDER DIFFERENT SYSTEMS OF CROPPING.

Table IX shows that corn, wheat, and hay yielded most when these three classes of crops were in rotation, and that corn and wheat yielded least when grown continuously. On none of the plats where hay was grown continuously was there a yield large enough to pay as compared with hay grown in rotation. 
TABLE IX.-Comparative yields of corn, wheat, and hay under different systems of cropping, 1899-1907.

\begin{tabular}{|c|c|c|c|c|c|c|c|c|}
\hline \multirow[b]{2}{*}{ Year. } & \multicolumn{3}{|c|}{ Corn. } & \multicolumn{3}{|c|}{ Wheat. } & \multicolumn{2}{|c|}{ Hay. } \\
\hline & $\begin{array}{l}\text { Corn } \\
\text { continu- } \\
\text { ously. }\end{array}$ & $\begin{array}{c}\text { Corn in } \\
3-y e a r \\
\text { rotation. }\end{array}$ & $\begin{array}{l}\text { Corn in } \\
\text { 5-year } \\
\text { rotation. }\end{array}$ & $\begin{array}{l}\text { Wheat } \\
\text { continu- } \\
\text { ously. }\end{array}$ & $\begin{array}{l}\text { Wheat in } \\
\text { 3-year } \\
\text { rotation. }\end{array}$ & $\begin{array}{l}\text { Wheat in } \\
5 \text {-year } \\
\text { rotation. }\end{array}$ & $\begin{array}{c}\text { Hay in } \\
3 \text {-year } \\
\text { rotation. }\end{array}$ & $\begin{array}{l}\text { Hay in } \\
5 \text {-year } \\
\text { rotation. }\end{array}$ \\
\hline $\begin{array}{l}1899 \ldots \\
1900 \ldots \\
1901 \ldots \\
1902 \ldots \\
1403 \ldots \\
1904 \ldots \\
1905 \ldots \\
1906 \ldots \\
1907 \ldots\end{array}$ & $\begin{array}{r}\text { Bushels. } \\
20.8 \\
37.5 \\
13.9 \\
11) \\
23.6 \\
11.1 \\
25.1 \\
27.6 \\
23.6\end{array}$ & $\begin{array}{r}\text { Bushels. } \\
51.1 \\
42.6 \\
42.0 \\
62.0 \\
54.7 \\
45.1 \\
64.1 \\
36.1 \\
35.2\end{array}$ & $\begin{array}{r}\text { Bushels. } \\
31.3 \\
58.0 \\
42.8 \\
78.6 \\
85.3 \\
37.1 \\
64.4 \\
60.5 \\
52.2\end{array}$ & $\begin{array}{r}\text { Bushels. } \\
22.5 \\
14.5 \\
16.0 \\
17.0 \\
16.3 \\
20.8 \\
20.8 \\
14.1 \\
24.5\end{array}$ & \begin{tabular}{|r|} 
Bushels. \\
25.3 \\
27.3 \\
13.5 \\
18.1 \\
24.4 \\
27.3 \\
20.6 \\
13.3 \\
19.1
\end{tabular} & \begin{tabular}{|r|} 
Bushels. \\
27.3 \\
25.6 \\
15.2 \\
25.1 \\
30.8 \\
32.0 \\
30.9 \\
22.6 \\
23.9
\end{tabular} & \begin{tabular}{r} 
Tons. \\
$\ldots$ \\
\hdashline \\
i. \\
1. \\
2.28 \\
3.86 \\
4.26 \\
4.86 \\
1.91 \\
1.25
\end{tabular} & $\begin{array}{r}\text { Tons. } \\
\cdots \\
2.36 \\
1.95 \\
3.10 \\
5.77 \\
5.81 \\
3.18 \\
1.42\end{array}$ \\
\hline $\begin{array}{c}\text { A verage, } 9 \text { years. } \\
\text { Gain } . . . . \ldots \ldots .\end{array}$ & 222.9 & $\begin{array}{l}48.1 \\
25.2\end{array}$ & $\begin{array}{l}50.7 \\
33.8\end{array}$ & $\begin{array}{r}18.5 \\
\ldots \ldots\end{array}$ & $\begin{array}{r}21.0 \\
2.4\end{array}$ & $\begin{array}{r}25.9 \\
7.4\end{array}$ & 32.85 & $\begin{array}{r}33.80 \\
.95\end{array}$ \\
\hline
\end{tabular}

Note. - The plats continuously planted to one crop and the 3-year rotation plats wère not manured. The 5-year rotation plats received 8 tons of manure every fifth year.

PROFITS INCREASE MORE RAPIDLY THAN YIELDS.

Table $\mathrm{X}$ shows the relative profits in Minnesota from larger yields of wheat or other crops as compared with smaller yields. Ten bushels of wheat have been necessary to pay the average cost, including a land rental of $\$ 3.50$ per acre.

TABLE X.-Showing net profit or loss from varying yiclds of wheat in Minnesota, years 1902-190\%, inclusive.

\begin{tabular}{|c|c|c|c|c|}
\hline Yield. & $\begin{array}{c}\text { Average } \\
\text { farm price } \\
\text { in Minne- } \\
\text { sota, } 6 \\
\text { years. } 1\end{array}$ & $\begin{array}{l}\text { Value per } \\
\text { acre. }\end{array}$ & $\begin{array}{c}\text { Cost of pro- } \\
\text { duction } \\
\text { per acre. } 2\end{array}$ & $\begin{array}{l}\text { Net profit } \\
\text { or loss. }{ }^{3}\end{array}$ \\
\hline 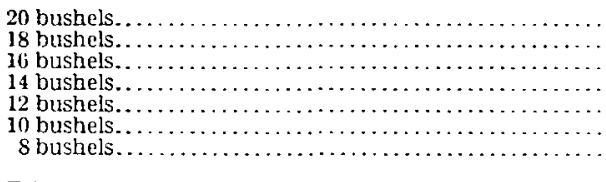 & $\begin{array}{r}0.742 \\
.742 \\
.742 \\
.742 \\
.742 \\
.742 \\
.742\end{array}$ & $\begin{array}{r}14.84 \\
13.36 \\
11.87 \\
10.39 \\
8.90 \\
7.42 \\
5.94\end{array}$ & $\begin{array}{r}\$ 7.61 \\
7.55 \\
7.49 \\
7.43 \\
7.37 \\
7.31 \\
7.25\end{array}$ & $\begin{array}{r}\$ 7.23 \\
5.81 \\
4.38 \\
2.96 \\
1.53 \\
-1.31\end{array}$ \\
\hline
\end{tabular}

1 U. S. Dept. Agr., Yearbook 1907, p. 623.

2 Minnesota Agrl. Expt. Sta. Bul. No. 117, p. 23.

Minus sign shows a loss.

\section{SUMMARY OF ROTATION EXPERIMENTS.}

(1) Cultivated crops, as corn, potatoes, and mangels, grown continuously, rapidly decrease the productivity of soils. This is largely due to the fact that cultivation stimulates decomposition of vegetable matter, leaving too small a supply of fresh vegetable matter in the soil.

(2) Grain crops grown continuously decrease the productivity of soils. This, it is believed, is in part due to reducing the fresh vegre- 
table matter which supports chemical and wholesome bacterial activity in the soil and in part due to an increase in weeds.

(3) A rotation of corn, oats, millet, and barley, which tend to exhaust the supply of vegetable matter, did not produce better results than continuous wheat cropping.

(4) A 2-year rotation of mangels and wheat, both of which reduce vegetable matter, gave little better yields of wheat than wheat continuously.

(5) A 2-year rotation of wheat and annual pasture gave greatly increased yields of wheat, presumably in large part because the annual pasture crop added fresh vegetable matter to the soil, greatly increasing the bacterial and chemical activities of the soil and improving its physical condition.

(6) A 3-year rotation of corn, wheat, and clover with no manure did not give as large yields of corn and wheat as were obtained from a 5-year "standard" rotation of corn, wheat, meadow, pasture, and oats, with some manure applied to the corn. The lower yield on the 3-year rotation is presumably due mainly to the fact that clover once in three years did not maintain the supply of fresh vegetable matter so fully as did the 5-year rotation with two grass crops and 8 tons of manure once every five years.

(7) Among the advantages of vegetable matter in the soil the following may be named: It aids aeration, retains moisture, deepens the soil, prevents baling, checks leaching and washing, stimulates decomposition, supplies easily usable plant food, affords favorable conditions for bacteria, increases chemical activities, and presumably aids in disposing of or neutralizing substances left by crops which are evidently toxic to the same or to other crons.

(S) The combination of cultivated crops, grain crops, and grass crops, including clover, as in the 5-year standard rotation, not varying greatly from two-fifths of the time in grass, results in substantial profits.

(9) In a word, the best rotation schemes yield $\$ 12$ to $\$ 16$ worth of crops, at a cost, including $\$ 3.50$ rental, labor, and all other expenses, of $\$ 7$ to $\$ 11$. With a net profit of $\$ 3$ to $\$ 6$ per acre, and under the conditions of the average farm there should be secured a net profit of $\$ 2$ to $\$ 4$ per acre on all the cultivated acreage.

\section{IMPORTANCE OF GRASS CROPS.}

Under the present farm and economic conditions in the middle Northwest many farms have too large a percentage of land planted to grains. This is shown by the facts given in Table III and also by. the fact that farmers may keep one-third to one-half of their land in grass and other forage crops and in the end make more money per 
acre and build up better farms. Continuous croppmg of grain, including the rotation of the small grains with com, results in reducing the amount of regetable matter in the soil and, unless the corn is in large proportion, in increasing the weeds and in otherwise reducing the productivity of the soil unt il the yields are no longer large enough to be profitable. On such farms, owing to the beneficial effect the grass and clover have in building up and cleaning the soil, it undoubtedly pays to increase quite largely the proportion of the farm kept in grass.

There are few cases in which hay or' other roughage can not be put to some profitable use on the farm, either by increasing the amount of live stock kept on the farm or at least by buying stock, cattle, or sheep to feed during the autumn and winter. In some cases hay and other roughage may be sold at a profit, even if it does remove vegetable matter and plant food from the farm. Dairy farming is especially favorable to keeping the soil well supplied with fermentable regetable matter, and therefore to the production of profitable yields of all crops. Besides, with due care in saving the manure, little of the nitrogenous and mineral fertilizing ingredients of the soil is wasted or removed from the farm.

Since the net profit on an acre of wheat, oats, or other small grain on run-down soit is very small, decreasing the crop of wheat and using the land for grass, aren though the grass can not be used to great advantage, will under such conditions not materially decrease the net profit of the farm. Table $\mathrm{X}$ shows that the margin of profit in raising wheat is not reached on lands on which the interest or the rental charge amounts to $\$ 3.50$ per acre unless the crop produces 10 bushels or more per acre and that profits rise rapidly with every bushel above that anount.

The cost of producing hay and pasture in Minnesot a and surrounding States is less than that of producing any of the other common field crops, als no extra preparation of the land or sowing is necessary, the grass seed usually being sown with the preceding grain crop. All the charges to be made against the grass crop are rent, cost of seed, and harvesting, and sometimes fencingr, and the crop in order to letum equivalent net profits does not need to yield a produdt with as large a gross value as corn or the small grains.

Where live stock is kept and the grass is marketed as beef, pork, mutton, or milk, the value of the grass or other raw product is often so increased as to malie a linger net return per acre than had grain crops been grown. In aldition to whaterer profits may be made by feeding the grass crops to live stork over selling it as hay, the grain or cultivated crop following the grass is usually stimulated to rield enough more than it would following a grain wop to be equivetent to that which would have been secured from two years of grain giving 
low yields. As a rule 75 acres of grain each year on land that grows a crop of clover every fourth year will yield a larger net profit than will 100 acres sown to grain continuously.

\section{THE USE OF STATISTICS OF COST OF FARM PRODUCTS}

In studying the question of farm management it early became evident that actual cost data would be necessary in determining the profits of any scheme of farm production. To collect this cost data the Bureau of Statistics of the United States Department of Agriculture, in 1902, joined in cooperation with the division of agriculture of the Uimnesota Agricultural Experiment Station to secure from Minnesota farmers the facts relative to the cost of producing field and live-stock products.

The work was carricd on under the supervision of the station officials, the Department and the station each bearing approximately one-latll the expense. The results already obtained from this line of farm-managrement rescarch, as published in various bulletins, have received the highest commendation and are being used both in economic discussions regarding the cost of production and in the organization of farms.

A plan was derised to secure the facts at first hand from general farners. Three so-called statistical routes were established in representative farm districts of the State, nimely, at Northrield, in southeastern Minnesota, at Marshill, in southwestern Minnesota, and at Halstad, in northwestern Minnesota. A student of the College of Agriculture was appointed route statistician and placed in charge of each route. These statistical routes have been continuously maintaincd up to the present time. The results of the first three years (1902, 1903, and 1904) are published in. L. S. Department of Agriculture, Bureau of Statistics Bulletin Xo. 48 and Ninnesotia Agricultural Experiment Station Bulletin No. 97. The average results for six years, 1902 to 1907, inclusire. are published in Bureau of Statistics Bulletin $\mathrm{No} .73$ and in Minnesota Agricultural Experiment Station Bulletin No. 117. The cost of producing dairy products, 1904 to 1909, is published in Bureau of Statistics Bulletin No. S8 and in Minnesota Agricultural Experiment Station Bulletin No. 124.

The Department of Arriculture and the experiment station inaugurated these cooperative investigations with a view to extending them to other States if the plan proved efficient and economical and the results warranted the expenditure. Subsequently, the Office of Farm Management in the Department of Agriculture developed a somewhat different system of securing cost of producing farm products. 
Under the route statisticil plan the figures for each route are based on data gathered by the route statistician from eight farms, chosen because they are typical of the general region in which the route is located. The route statistician goes daily to each farm, securing a detailed statement of man and horse labor expended upon various enterprises for the previous day, cash expenditures and receipts, feeds fed to all classes of live stock, amounts of farm products used in the household, and other items, as yields of crops. Summarics of these results are sent monthly to the central office, where they are recorded in the set of double-entry books which is kept for each farm on the route, and at the end of the year a business statement for each farm, showing gains or losses on each enterprise and on the farm as a whole, is prepared at the central office and sent to the owner of the farm.

Under the individual farm plan of the Office of Farm Management, on the other lland, the filmer himself keeps a daily record of time of men and horses spent on each enterprise, a record of yields, cash expenditures, and other items, and reports periodically to the central office on forms supplied to him.

These two methods are being compared, and it is evident that, besides being checks upon each other, the first plan is better adapted to some conditions and the second better to other conditions, and that a combinition of the two plans will best sccure the desired results. By combining the two methods of inrestigation plans have been developed under which general lat a of the cost of farm products should be secured in each and erery State at the earliest practicable date.

To use these diata of the cost of producing live stock and other products the firmer needs to organize his farm somewhat systematically and to have a knowledge of simplified forms of recording the results of his farm products in terms of money. He should correct these publiwhed firures of the cost of production so as to make them applicable to his conditions and to apply them to the values of his products in such a manner as to enable him to determine net profits. He will then be able to compare the net profits of each kind of crop, of each system of rotation, and of each general method of farm management on his own farm, on the farms in the vicinity, and on farms in other localities.

The following tables, based on Bureau of Statistics Bulletin No. 73, give some of the raluable facts secured by these investigations: 296 
TABLE XI.-Average annual cost per acre of producing field crops, 1902-190\%, including rental of land.

(See L. S. Dept. Agr. Bureau of Statisties Bul. 73 and Minnesota Agrl. Expt. Sta. Bul. 117 for detailed tables.)

\begin{tabular}{|c|c|c|c|c|c|}
\hline Crop. & $\begin{array}{c}\text { Number of } \\
\text { table which } \\
\text { shows de } \\
\text { tailed cost. }\end{array}$ & $\begin{array}{c}\text { North- } \\
\text { feld } \\
\text { (Rice } \\
\text { County). }\end{array}$ & $\begin{array}{c}\text { Marshall } \\
\text { (Lyon } \\
\text { County). }\end{array}$ & $\begin{array}{l}\text { Halstad } \\
\text { (Normanan } \\
\text { County) }\end{array}$ & $\begin{array}{l}\text { Minne- } \\
\text { sota Agrl } \\
\text { Expt. } \\
\text { Sta. }\end{array}$ \\
\hline 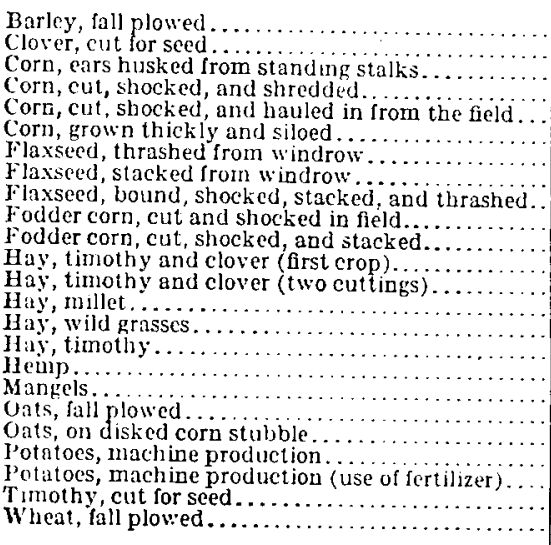 & \begin{tabular}{|} 
XIV \\
XVI \\
XVII \\
XVIII \\
XIX,XX \\
XXII \\
XXII \\
XXIV \\
XXV \\
XXVI \\
XXVII \\
XXVIII \\
XXIX \\
XXXI \\
XXXII \\
XXXII \\
XXXIV \\
XXXV \\
XXXVI \\
XXXVII \\
XXVIII
\end{tabular} & \begin{tabular}{r}
89.647 \\
6.500 \\
11.658 \\
15.297 \\
\hdashline 2.62. \\
10.072 \\
$\ldots . . \cdots$ \\
10.733 \\
12.362 \\
6.185 \\
7.178 \\
9.317 \\
6.036 \\
$\cdots 6.741$ \\
$\cdots 9.854$ \\
9.158
\end{tabular} & $\begin{array}{c}\$ 8.880 \\
\ldots \ldots 662 \\
9.66 \\
10.265 \\
\ldots \ldots . \\
\cdots 8.861 \\
8.400\end{array}$ & \begin{tabular}{l}
7.272 \\
7.028 \\
0.895 \\
8.912 \\
\hdashline .567 \\
6.349 \\
2.970
\end{tabular} & $\$ 19.187$ \\
\hline
\end{tabular}

TAELE XII.-Cost of labor operations per acre at various points in Minnesota. ${ }^{1}$

\begin{tabular}{|c|c|c|c|}
\hline Crop. & $\begin{array}{l}\text { North- } \\
\text { field (cost } \\
\text { per acre). }\end{array}$ & $\begin{array}{c}\text { Marshall } \\
\text { (cost per } \\
\text { acre). }\end{array}$ & $\begin{array}{l}\text { Halstad } \\
\text { (cost per } \\
\text { acre). }\end{array}$ \\
\hline 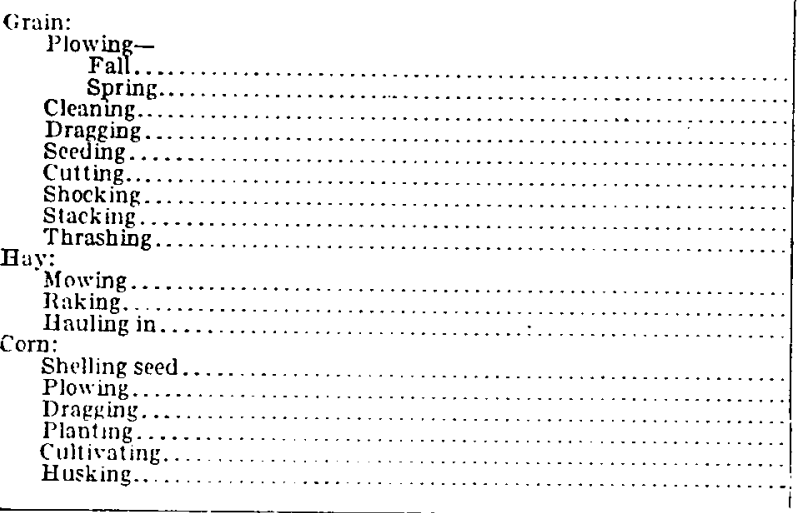 & $\begin{array}{r}\$ 1.250 \\
1.311 \\
.023 \\
.239 \\
.371 \\
.460 \\
.218 \\
.789 \\
.528 \\
.368 \\
.178 \\
1.099 \\
.026 \\
1.311 \\
.544 \\
.240 \\
1.806 \\
3.456\end{array}$ & $\begin{array}{r}81.141 \\
1.171 \\
.035 \\
.172 \\
.236 \\
.333 \\
.110 \\
.539 \\
.257 \\
.328 \\
.213 \\
1.242 \\
.025 \\
1.171 \\
.439 \\
.255 \\
1.453 \\
2.473\end{array}$ & $\begin{array}{r}\$ 1.130 \\
1.186 \\
.030 \\
.281 \\
.272 \\
.333 \\
.135 \\
.481 \\
.312 \\
.363 \\
.248 \\
1.972\end{array}$ \\
\hline
\end{tabular}

1 From U. S. Dept, Agr. Bureau of Statistics Bul. 33 and Minnesota $A$ grl. Expt. Sta. Bul. 11 .

Note.-Table XII comprises only those items which are composed of labor alone.

\section{METHODS OF USING FARM-MANAGEMENT DATA.}

In subsequent pages of this bulletin an attempt is made to give some of the formal methods needed by the farmer in utilizing the results of such experiments as the rotation experiments previously mentioned. the results of the investigations to secure data as to the 
cost of farm products, and data secured as to yields and values in his own fields and barns; that in a simplified way he may be able to compare the relative profits of his crops, his rotation schemes, his methods of live-stock production, and his general methods of farm management, both within his own farm and with other farms.

The eftort is also made to offer a pedagogical plan under which the teacher in the college of agriculture, in the agricultural high school, and especially in the consolidated rural school, or even in the one-room school, wherever farm pupils are taught, may be able both to teach the general principles of farm management, and to give the pupils skill in making comparisons and efficiency studies in relation to farm methols and practices.

It is not too much to liope that attempts at placing farm organization and farm management on an engineering basis will result in a research and educational movement which will help to give to all firm youth training in the elements of scientific furm organization; will help to produce efficiency farm engineers, as there now are effiriency engineers in manufacturing enterprises; and will holp cventually to transform the generally poorly organized farm business in to a business with scientific plans and highly efficient management; and will yet retain the family-size farm where folks are the greatest product.

\section{FARM-MANAGEMENT INVESTIGATIONS NEEDED.}

The cultivated area of the farms of the Cnited States is approximately 500,000,000 acres; and the value of the crops from this cultivated area is about $\$ 5,000,000,000$. Work already done by the State experiment stations and the General Government has shown that by better methods of crop rotation alone this product can be increased easily $10 \mathrm{per}$ cent, or $\$ 500,000,000$, or $\$ 1$ per acre. The States and General Government having assumed the task of carrying forward agricultural research and agricultural educition, have thus brought themselves fuce to face with the problem of leading the farmers into this increased production. Extension of the methods which have shown the possibilities of improved methods of farm organization promise to carry this work forward on ali the farms of the country, thus bringing up the averase of the whole. The leading plans, mentioned below, are proving adapted to the work of investigation and educition so as to reach all dintricts of each and cvery State.

\section{CROP-ROTATION EXPERIMENTS NEEIFU.}

There is needed in each State, valley, or even county or lesser district with distinctive agricultural conditions, experiments on series of uniform plats, to compare $10,20,30$, or more of the secringly 
most practical rotation schemes. Some of these should be especially devoted to determining which rotation schemes pay best without fertilizers, and in others commercial fertilizers should be supplied to one or more of the crops. In Minnesota the experiments reported in this bulletin show broadly some of the unsuccessful cropping schemes and others which are successful, thus helping to narrow down the further trials to the more practicable plans. Sufficient land should be available so that cach rotation scheme would have a plat for each year in the rotation, and the more important rotations should be on duplicate series of plats. Several hundred one-tenth acre plats at the State experiment station and at each of nine branch stations would fairly compass the needs for the more scientific part of the field work in a large State like Minnesota or Iowa. In a State broken. up with many valleys, more branch stations are needed. The land for these plats should be most carefully chosen by careful inspections aided by means of soil borings, discarding all portions of the fields not reasonably uniform. The plans should be carefully made and passed upon by a large committee of the best experts in farm management, plat testing, and soils in the State stations and in the United States Department of Agriculture. Men should be employed to do the work who make this their first duty, and the greatest care should be taken to have all controllable factors under control. Constant physical, chemical, and biological surveys and tests of the soil should be made, and samples of the soil and of the crop should be regularly kept.

The possibilities and importance of the lessons to be deduced from the data after 10 or 15 years are foreshadowed in the results shown in Tables I to IV. Data thus secured in a broad way would help make the teaching of crop rotation as practical as the teaching of bridge building.

\section{COST OF FARM PRODUCTS.}

The results given in Table XI, p. 41, of the cost of producing farm products and their use in various ways throughout this bulletin demonstrate the fact that such data are enormously useful, both to the farmer and in the school. And that they can be secured in general agricultural areas and in limited areas of special conditions or special farming has been amply proven. That these data can be applied to the results of rotation experiments, as well as to the results on farms organized for crop rotations, is amply demonstrated throughout this bulletin.

THE VALUE OF FARM PRODUCTS.

Tests were applied to determine the accuracy of the average prices at the farm of the various farm products as published by the Bureau 
of Statistics of the United States Department of Agriculture, and these data were found reasonably accurate and more reliable than any other available data.

\section{FACTS FROM SUCCESSFUL FARMERS.}

The facts being gathered by such organizations as the Office of Farm Management of the United States Department of Agriculture and State experiment stations, and similar data gathered by farm demonstration men and others whose research or instructional work brings them in contact with the business of bright farmers, are gradually being accumulated into a borly of usable knowledge. This knowledge is rastly more cxtended than that which is secured by formal rotation experiments, but it greatly needs the more carefully wrought-out work of the rotation plat tests, controlled by the results of the laboratory and the cost tables, to correct it and reduce it to a more scientific basis. Eventually the experimenters, the farm management experts, the farm demonstrators, the teachers in consolidated rural schools, and in higher. country-life schools, and the writers of textbooks will put all these data to the test of comparative research. They will finally be compared in the terms of the farmer's own results. When the supreme test of profit with improved soil productivity is applied, farmers will settle down to using those plans which give a large product per acre and per farm worker.

\section{THE TEACHING OF FARM MANAGEMENT.}

The presentation of the subject of farm management in the classroom to students who have grown up on the farm and are therefore conversant with the average farm conditions and diffeulties is a most delightful experience to the teacher who is really master of the subject. In the Minnesota School of Agriculture, where the plans herein presented were devised, the students, about two-fifths of whom are girls, come from the rural schools and spend three winters of six months each in the agricultural high $h_{-s c h o o l}$ course, and nearly all return to the farm. During the first yoar of the course each student, after receiring brief instruction in farm planning, is required to draw a plan of his own home farm with the fields as they wore farmed the previous year. The second year, in the classes in field erops and farm management, he is required to make a map of the farm as cropped during the intervening year and to accompany this with a business statement and invoice showing the kinds of lire stock used, sales, and similar data. Each student is then required to project a plan for reorganizing the fields and farm scheme generally, as shown under students' plans further on in this bulletin.

The most wholesome and intense interest is thus developed in the students concerning the cfficiency of the plans in vogue for their home 
farms and in the possibility of increasing products and profits by the reorganization of the farm. Each student is led to a keen appreciation of the advantages as well as the deficiencies of his home farm. The girls as well as the boys take a deep interest in this subject, and their work shows that they grasp the significance of the farm plan deliberately made, as compared with many of the home farm plans which, like "Topsy, "just growed." And the intelligent discussion of definite plans of farms under conditions with which the students are familiar rapidly educates their judgment as to the relative values of crops, methods of crop rotation, methods of farm management, and methods of the care and marketing or use of crops and live stock. No better methods have been devised of teaching judgment in practical farm matters, so that the farmer can better learn from his own farm conditions.

That this subject is not over difficult is annually demonstrated by the fact that most students after a reasonable amount of instruction, in which numerous farms are discussed before and after reorganization, succeed in making at least fairly acceptable plans for their home farms: In some cases the student is able to be in constant consultation with his father, in which case the plan finally adopted is based on the combined judgment of the student, his father, and the teacher. In numerous cases the father has chosen to put into operation the plan thus developed, and frequently students themselves have come into the management of the farm and have adopted the plan as made at the school or as further devcloped as experience and knowledge of the farm conditions made advisable.

TEACHING FARM ORGANIZATION IN CONSOLIDATED RURAL SFHOOLS.

The two thousand consolidated rural schools already established and the tens of thousands for which there is room and need among the 6,000,000 farms of the Linited States offer the most natural place to teach the subject of farm organization. Here the school principal, if he is experienced and trained in this subject, has the most unique of pedagogical opportunities. Given typical conditions-of 150 pupils from as many farms, coming in public-school wagons to a central 5-room school, with its 5 teachers, one of whom is trained to teach agriculture and one home making, a 10-acre school farm, and laboratory facilities - there will be about 50 pupils in the seventh and eighth grades and in the first two high-school years. These 50 pupils will generally attend school 6 months and work on the home farms the alternate 6 months, giving the teacher of agriculture opportunity, while halping supervise their home work, to become acquainted with their home farms. Thus scores of farms will be the practical basis for much of the instruction in farm management. The outer half of the school farm can also be developed as a demonstration and practice 
laboratory, where crop rotations, methods of soil fertilization, and ways of cultivating crops can be demonstrated, and practice can be given the pupils doing many things well under the critical eye of the master.

Beginning at the fourth grade, the pupils can be required, in connection with their geography, to construct a map showing at least approximately the plan of the home farm for the previous year, as in figures 18 and 20 . If the farm has been carefully laid out and measurements are known, the pupil's map can be made to scale with some accuracy. At the close of each crop year the pupil can be required to make a map of the farm, showing the cropping scheme and
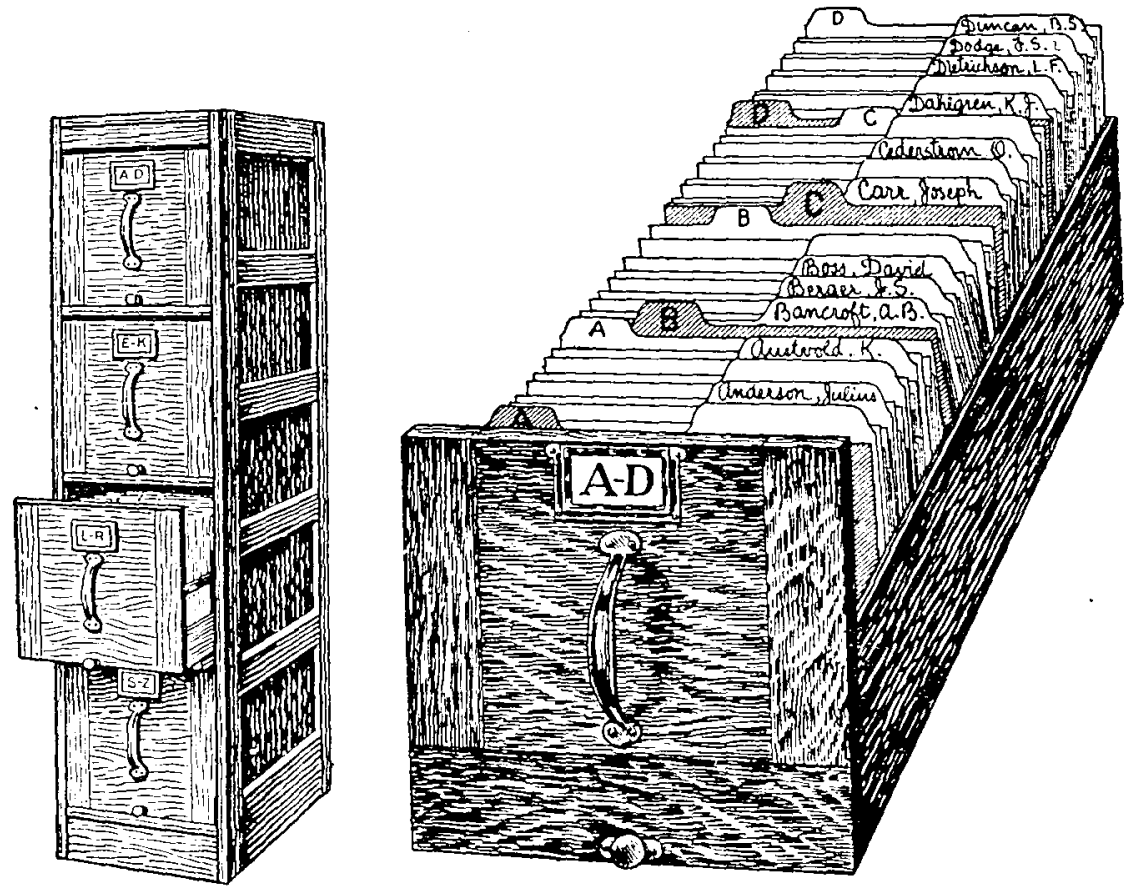

Fig. 11,-File case for farm-management st udents' work.

other features for that year. Thus at the end of the tenth grade, or middle high-school year, he will have made seven annual maps of the home farm. The general form of these annual maps can be fashioned somewhat after the plan shown in figure 22, and thus serve as a history of yields, prices, and other items, as well as of the kind of (rop grown on each field.

There should be in each.consolidated rural school a suitable filing case such as is used for ordinary letter filing, taking sheets $8 \frac{1}{2}$ by 11 inches. (See fig. 11.) Each student should be allotted a place in this filing case with one or more division cards carrying his own name. In this file each student can place his annual maps and such other 
maps and statements of the farm business as he makes from time to time as a part of his class work.

Before the student passes out of the consolidated rural school, at the age of 16 to 18 years, he or she can be required to plan the reorganization of the home farm on a key map as shown in figure 15, and such supplementary maps as transition maps, figures 12,13 , and 14 ; also maps for annual records, as in figure 16, and likewise maps for records of manuring, as in figure 17, supplemented by such forms for tabular statements, summarized records, invoices, and other forms as may be made part of the school work. Table XIII is given as an example. In column 5 is shown the manner of entering the crops and acreages by fietds for a given year. In Table XIV is shown a form of tabu-

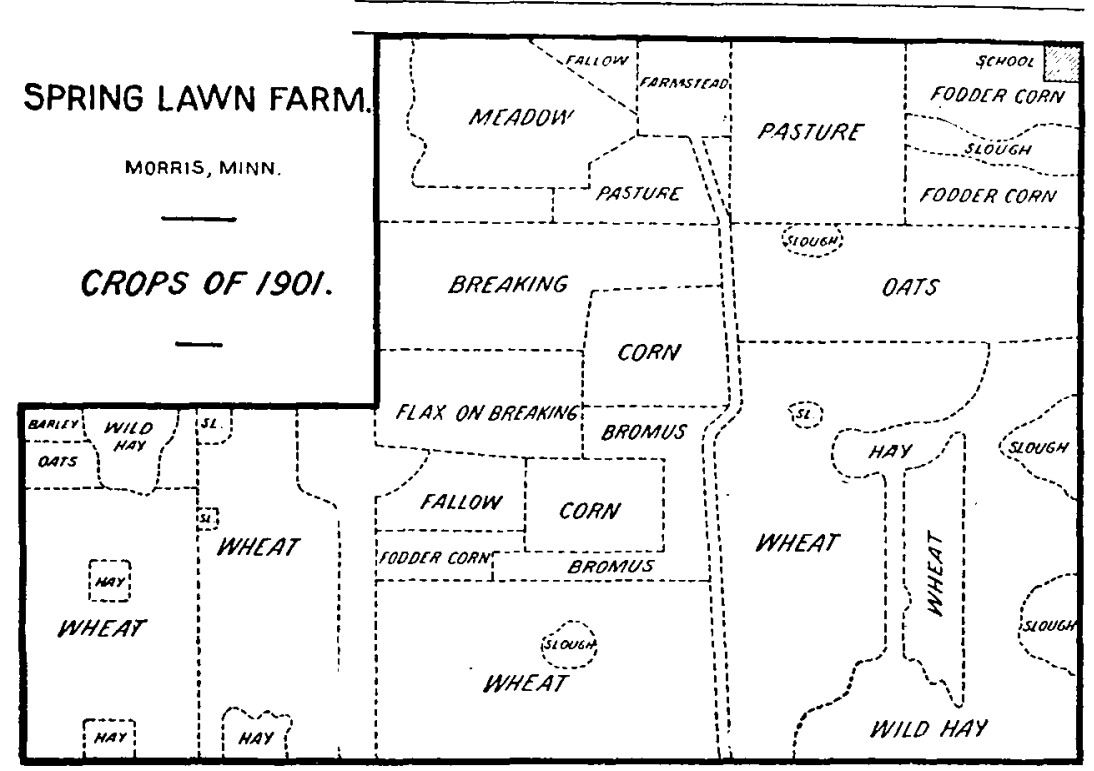

FIg. 12.-Spring Lawn Farm in 1901, with fields as handled from year to year by successive renters who had no interest in the permanent plan nor in the future productivity of the fields.

lating the gross product, the yield per acre, the price, the cost, and the profit per acre by kind of crop. On similar blanks can be tabulated for a series of years each class of facts, as yield, price, or net profit, that averages may be struck for a series of years.

These school activities in connection with the home farm will result in the boy or girl early entering into discussions at home with the parents concerning the management of the farm, bringing home to the parents somewhat of the viewpoint of the formalities of farm organization.

When the maps have accumulated covering the entire series of years in the rotation, a summary map can be used in which can be recorded the averages representing the product of each field for the same series of years. 
In Table XIV is griven a blank form suggesting the manner of assembling under box heads data from a large number of fields. The student is required to prepare this tabular form and to place in it the atcreages from the annual history sheets, and, as shown in Tuble XIII, projected from his key map. This excrcise enables the student to check up his key map so thit each rotation is carefully worked out in each field and it also teaches him a general plan for arranging and tabulating a form on which can be entered the yields of the respective crops on the various fields.

Each student may then be required to make a statement showing the proportion of each crop to be fed out on the farm, to be sold on

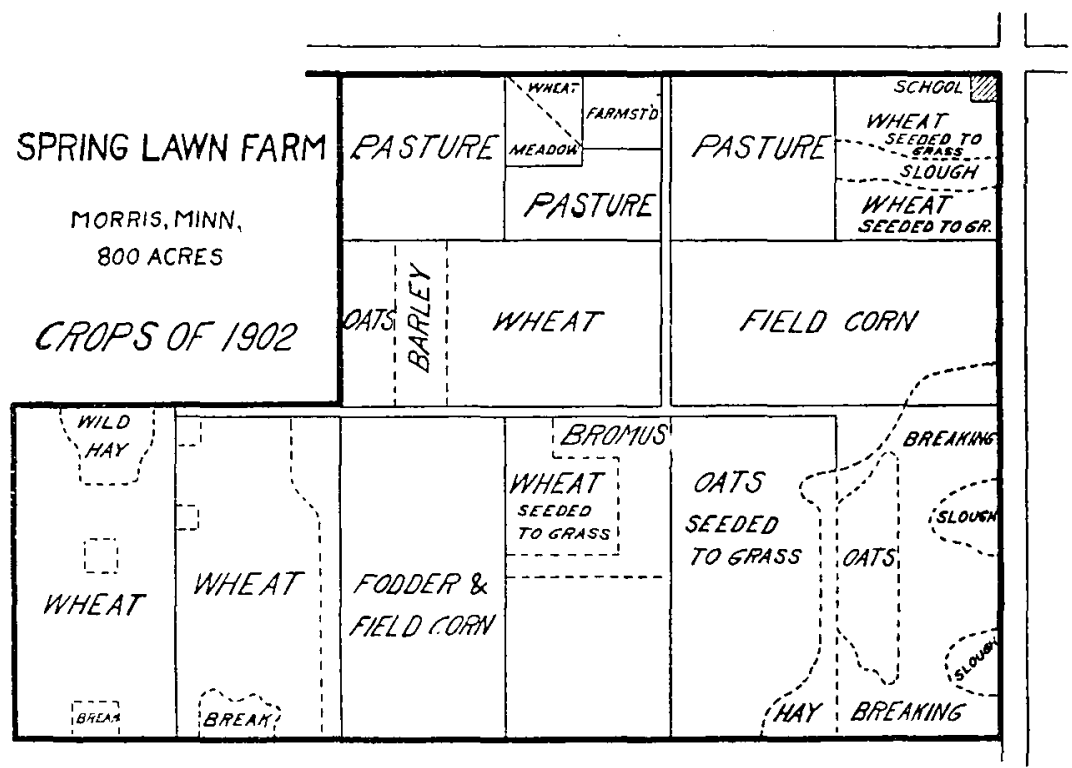

F1G. 13.-Spring Lawn Farm in 1902, the first transitory year, showing the first steps in the transition from the unsystemat ic farm in 1901, shown in figure 12, to the permanent arrangement of fields as outlined on the key map in figure 15. Note that the irregular pieces of wild hay land are being drained and broken atd some of the old fielils seeded to grass.

the market, or to be disposed of in other ways, and to designate the hinds and numbers of animals to be fed these crops with such purchased feed and sales of crops as he may propose. IIe may also be required to give plans for buildings, an itemized statement of machinery and implements required to show the proportionate value of equipment and land, and other similar data. He should also be required to give two invoices, showing the form of invoice at the beginning of each of the two years and also showing the relation of this invoice to the definite system of accounts he may desire to use.

If a system of double-entry farm bookkeeping is taught separately from the classes in farm management, it should be in some harmony with the plan of keeping records under the key map. 
While the plans made during the consolidated rural-school course will be largely products of the students, they will represent many earnest discussions in the home, among the students, between the student and his teacher, often between the teacher, the student, and the farmer, and many times between groups of farmers. Both in the school and in the home and neighlorhood discussions, such figures as are given in Tables XIII and XIV, also Tables XI and XII, giving averaged relative yields, values, cost, and net profits, as published by experiment stations and departments of agriculture, will be extensively used. Averages from the farms of the district, especially once 10-year averages are available from a number of systematically

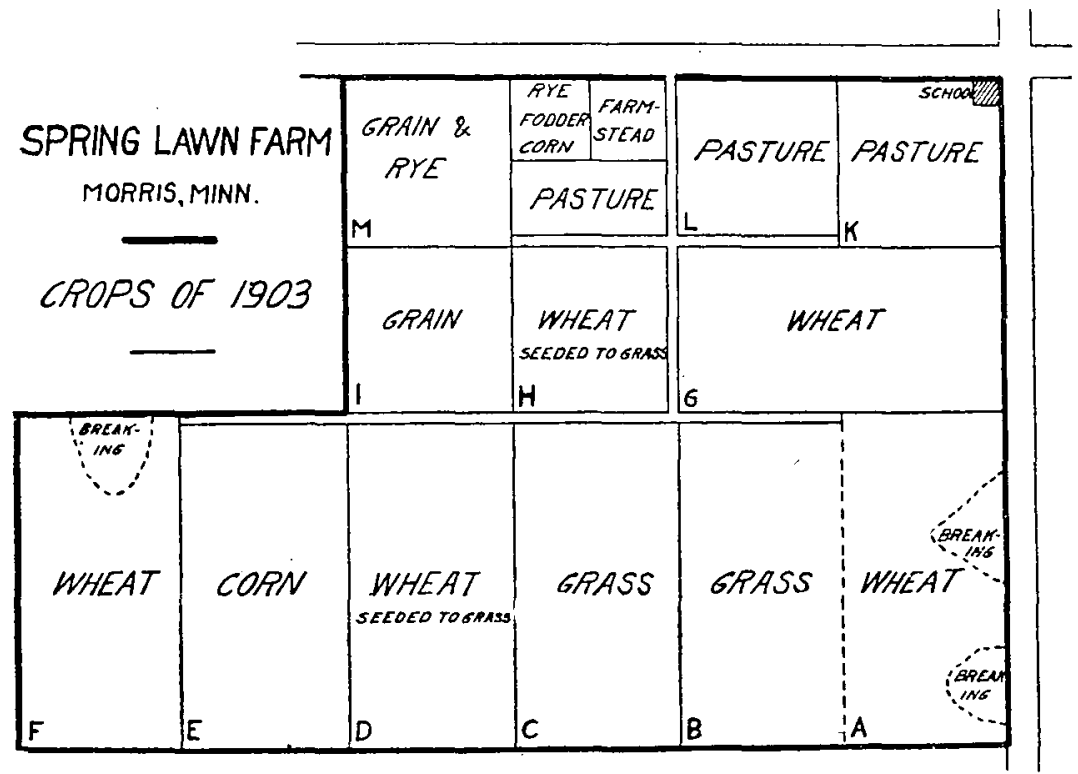

FIg. 14.-Spring Lawn Farm in 1903, showing the second transition year, where crops on a number of fields have been brought into the regular rotation. The fields have all been formed up as they are to be permanently. The last of the sloughs are drained out and broken ready for crops in 1504. Two fields, J3 and $C$, are in grass, and $D$ is seeded. The three will jurnish the pasturage and hay for the next yoar.

arranged farms, will also become very uscful parts of these discussions. And thus centered about the sohool will be most vital efficiency discussions concerning the methods commonly employed in the management of the farms of the district and county.

It is manifest that the character and value of these discussions and of the instruction will depend mainly on the ability, earnestness, and tact of the teacher of agriculture. It is also manifest that if a teacher can thus be the center of vital discussions annually of the methods of managing the farms, the value of his serviees will be cumulative, leading to longer tenure in this important office as principal of the consofidated rural school in the rising scheme of education for country life. In the most vital way this bringing 
of the organization and reorganization of each farm into the school work will eventually give the wirle-awake teacher a general and even a detailed knowledge of most of the 100 to 200 farms of the consolidated rural district. It will give him great slill in making farm plans and in judging as to the best combination of crops in rotation, as to the best arrangement of live stock with the cropping scheme, and as to the general system of farm management which will best meet the conditions of each farm and farm family. The young man who desires to enter the profession of efficiency farm engineer can hardly find a better opportunity to learn the practical side of his business than to spend a few years after taking his college course in the principalship of a consolidated rural school in the district where he must thus make good in teaching this subject in a community of progressive farmers.

And it seems easy to forecast that, from the ranks of those who succeed as principals of consolidated rural schools, not alone in teaching farm management but in teaching many farm subjects and in dealing with the general problems of country-life education, will be chosen the men who will place on a more efficient basis the office of county superintendent, who in turn can greatly assist in hringing about uniformly efficient teaching of farm management and other agricultural subjects in the consolidated rural schools of the country.

Both the rotation key maps and the transition maps serve as excellent bases for discussions of farm-management problems with the entire class. This is especinlly true in the consolidated rural school where the father's and older brothers also take a lively interest in suggestions for reorganizing the farm plan, thus bringing to the school through the pupil many questions which arise in the actual business of the farm

TIE KEY-MAP METHOD OF ORGANIZING THE FARM.

That the key-map methol of organizing or reorganizing a farm aids in giving definiteness and accuracy is demonstrated by figures 12 to 17 of Spring Lawn Farm and the accompanying statements. This plan is especially valuable in that it clearly sets out the various rerops, rotation schemes, and plans of organizing the farm for commarison as accurate as the available information will allow. This makes it especially useful in the school, where it becomes a means of so standardizing the work that the student can easily follow the work of his fellows.

The eflort has been to devise a graphic language adaptable alike fir the plan drawn by the student, the stereopticon, and the printed piage. Color schemes for designating the several crops and other derices have been tried and discarded for the simple map with the nume of the ficld, the acreage, the crop, and the year all inserted 
as plainly as print. Even the weight of the heavy farm boundary line and of the field lines have been found matters worthy of somo attention as to uniformity. And the use of arrows has been resorted to as a help in at once secing the order in which the crops "rotate" from one field to another and returning repeat the same order of rotation.

TABLE XIII.-Student's tabulation of acreages by crops and fields.

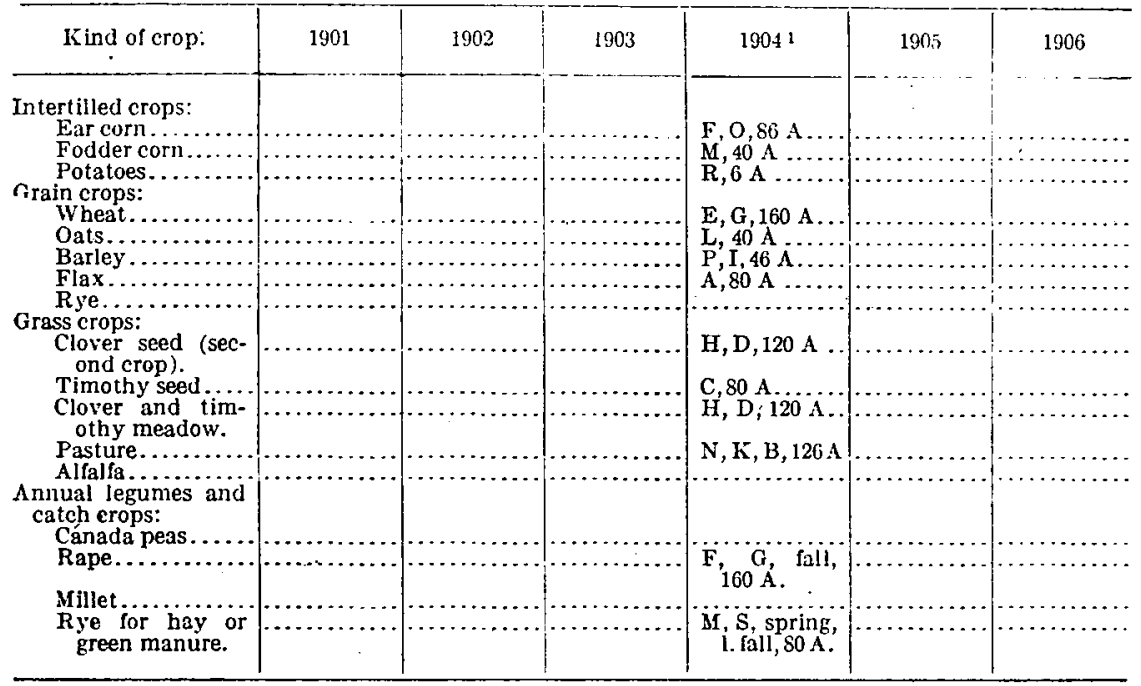

1 See key map, fig. 15 (p. 56).

TABLE XIV.-Siudent's tabulation of field records.

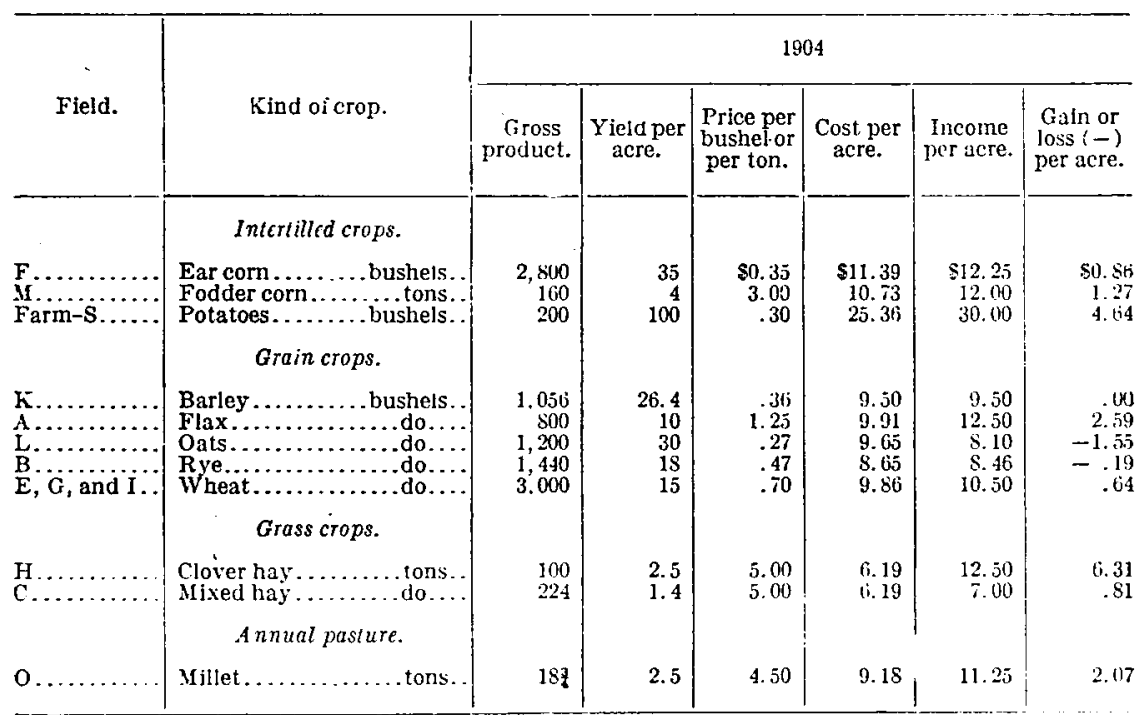


TEACHING FARM MANAGEMENT IN AGRICUTTURAL IUGH SCHOOLS.

The conditions of a large agricultural high school, such as those at St. Anthony Park, Crookston, and Morris, in Minnesota, and those in each congressional distriet in Georgia and Alabama, aflord falvoiable conditions under which farm management can be taught to thene who are to become farmers; and also to those who are to teacle agriculture in consolidated rural schools, or in the 1-room district sritool.

The students attend the Mimnesota schools named above only in winter, spending the alternate 6 months on the home farm or, it they are not from farm homes, as employees on farms where both the ar tual farm life and the work of the farm can be learned. The pratice in the school at St. Anthony Park has been to include a few lectures on farm planning in the first year and to require each student to make from memory or by visitation to his home a plan of his. home farm or of that farm which is best known to him. (See samples of these maps in figs. 18,20 , and $2 \cdot 2$.)

The second yoar in the classes in farm management the student is required to make a map, a business statement, and an inroice of the home farm for the intervening year. (See figs. 13 and 14.) The student is then required to make a key map as in firmes 15, 21 , and 23 , setting the beginning of the rotation a fow years ahearl so as to give time to gradually move fences and lanes, and to transform the old scheme of cropping into the new. IIe is then required to project a scheme of transition maps for the intervening years, as in figures 13 and 14 . Ile is also required to arrange a system of annual record maps in which to place a record of the crop grown, yiehl per acre, price, gross income, income per acre, net profit, and surh other data as are desired.

In case a soil has long been so subjected to a laulty systen of cropping that it is very unproductive, it is often necessiry to first utilize a system of cropping which will bring the soil part way up to a productive state before installing a permanent rotation seheme. Thus in Virginia a 2-year rotation of corn and three green-manure crops might be used for 4 or 6 years on very poor soil before installing a permanent 5-year rotation: First year, corn; second year, grain; third and fóurth year's, grass; fifth yoar, corn. The 2-year preparatory or soil-building rotation is as follows: First year, corn, with crimson clover sowed among the corn; second year, plow under the crimson clover, sow cowpeas, plow under the cowpeas, and sow rye; the second '-year crop rotation is begun by plowing under the rye and planting corn.

COMPLEX ROTATIONS.

The varioty of conditions which may be met and yet adhere to a system is surprising. The key map as a guide makes more variations 
of crops practicable than can be devised where no plan is projected forward. With the key map the farmer not only has a history of his cropping, but he can look forward and see how any temporary changes in the crops is likely to affect future crops.

Thus alfalfa can be brought into combination of a 5 -year rotation on 6 fields, though the seeding of this crop is so expensive that it does not pay to plant it unless it can be left for several years. The alfalfa can be placed on one field for 5 years, while the other crops can be rotated on the other 5 fields, when the alfalfa can be shifted to one of the other ficlds and its first field come into the 5-year rotation. Thus we have a 5-year rotation in rotation with a single crop, forming a 5-year complex rotation.

Since the alfalfa can be shifted at the end of 5 years to any other field, its former field receiving the crops of the 5-year rotation, there is little or no complexity about this plan. It will only be necessary to shift the alfalfa to a field where it will not interfere with seeding to grass. In like manner one or more frelds of about the same size as those under rotation can be planted to permanent grass mixtures for either pasture or meaklow, and when they die out, become weedy, sod bound, or otherwise unproductive another field can be seeded down and the grass field can be plowed up to take its pluce as one of the rotation ficlds. Students have no little interest in working out unusual cropping schemes and devising mapping schemes which will clearly display their seemingly difficult propositions.

The basis of fact as to plans of farms, kinds of rotations to be used, crops srown, eost of peoducing farm products, etc., given in this bulletin is naturally limited in its usefulness in or out of school work in pemote states. But the method of teaching here presented will be found helpful and suggestive in all States. And the use of plans of teaching here presented will doubtless help to create a demand for the extension of the cost-keeping investigations developed in connection with this ffort to devise methods of teaching farm management.

The methods presented herewith are designed not only to serve as aids to teachers of farm management but also to be used by the practical farmer in organizing or reorganizing his farm. Farm efficicncy teachers, commonly known as demonstration farmers, employed at public expense to help farmers reorganize their business will find the key-map scheme of planning and recording the plans of farms most uscful. When once the county has a group of farms thus systematically organized in each township or consolidated ruralschool district, and the leading facts of yiclds, profits, etc., are recorder on eich for a series of years, the demonstration farmer will truly have demonstrations of entire farms, scientifically managed. Some of these farms will be models both in form and in net profits. 


\section{APPENDIX.}

\section{INSTRECTIONS TO STUDENTS.}

Each student is requircd to make a set of drawings of his or her own home farm or of that farm with which he or she is most familiar, following the general plan of those in figures 12 to 14 . Make first the first-year plan regarding the present management of the farm, as in figure 12, and then construct a key map, as in figure 15, and fill in the transition maps, as in figures 13 and 14 , for each of the interrening years, providing for the actual changing of the oll forms of fichls and the farm system of cropping so as to bring into operation the new plans of fields, crop rotations, and systems of caring for live stock, as outlined in the key map. Place the rotation key mit) a suficient number of years ahead so that under the transition milps the fields can be gradually brought into the permanent scheme of cropping. Should exigeneies arise in the farming making it necessing, additional transition maps can be made, longer delaying the full adoption of the key-map plan, thus making it easy to take the longer number of years before bringing the farm entirely under the plan on the key map. Owing to rery dry yesis and other irregularities the key map can not always be adhered to. The history milp will show the changes actually made. And sometimes it is necessary to project on transition maps a program for changes for two or more years, then to return to the plan on the key map. When these exigencies show that the plan on the key map is fundamentally wrong or the conditions have changed, a new plan can be projected and a new key map made for the future guide.

Make statements of farm developments and changes which are to be made preparatory to the reorganization of the fields, such as clearing off trees or stones, drainage, irrigation, fencing, and the replanting of groves, thus to determine in the beginning the permanent forms and sizes of the fields. Write out especially noteworthy features of the proposed plan; give the acreage provided for each class of crops in the new plan, preferably in a tabular statement under some such form as that shown in Table XIV. Give an estimate of the number of each class of live stock proposed to be kept under the new plan. Write in detail the faults of the old plan of the farm organization. 
Write rotation schemes as follows: Five-year rotation: First year (10 loads manure per acie), corn; second year, grain; third and fourth years, clover and timothy; fifth year, grain. Suggest new ways of expressing plans, drawings, and other details. Devise now schemes of teaching farm management, now plans of rotating crops, and arranging fields, new methods of growing, handling, and using crops. Place the date and your full name on every drawing and paper. ${ }^{1}$

\section{GLIDE FOR STLDENT'S WRITTEN STATEMENT.}

JANLART, 1902.

Figure 12 shows Spring Iatwn Farm as it appeared in 1901. It is situated 6 miles southwest of Morris, in Stevens County, Minn., and consists of soo acres of land, section 29 and southeast quarter of section 30, township 124, range 42 west.

The farm h:s been deroted largely to grain growing for about 15 years. Only a little manure from the live stock has been added to the soil and hut lit te tame grass or clover have been grown, though these crops have tone well when sown. The soil is uniformly a clay loam with strong diy subsoil, with good ability to absorb and retain water, which is supplied to crops in time of drought. In years of unusual rainfall the soil is inclined to be heary and wet. This map) shows that 30 irregular fields have been made by annually breaking one portion after another of the native prairie sod. The quarter section on the west was added to the main farm by recent purchase.

The soil is not radily rorkel in wet seasons and some portions need drainage. 'The farm is undulating and natural drainago is provided except on limited areats, and these areas can be drained for the most part with sufface drains at slight expense. Some tile drainage will be necesary. The soil is fairly rich, and being rather heavy will not leareh and will long show the effects of applied manures.

The rotation key mal , figure 15 , shows the projected scheme of crop rotation for farm management. The seven 80-acre fields, $\mathrm{A}, \mathrm{B}$, $C, D, E, F$, and $G$, provide for a seren-year rotation: First year, grain; second year, corn and rape; third year (manure 10 tons), corn and rape; fourth year, grain; fifth year, grass; sixth year, grass; seventh year, pasture, as shown in field $A$. In field $A$ the grain, with which the rotation statement begins, is in 1904; in B in 1905; in C in 1906: thus down to the last of the seven fields, G, when it is in 1910 . Then starting down through the series of seven fields, grain is again in ficld $A$ in 1911. At the end of the serenth year a new key map can be made in which the rotation sequence stated in the respective fields, as in figure 15, will simply-be extended for another period of years.

1 The teacher shoul threa date stamp th the classioom and should stamp the date of receipt on all papers, or, if it is not possible to secure a date stamp, should write the date on each shcet. 
The five 40-acre fields, H, I, K, L, and M, are to be under a 5-year rotation: First year, grain; second year, grass; third ycar, grass; fourth year, grain and rye; fith year (10 loads mamure per acre), corn, planted thickly for fodder, as shown in figure 15. Owing to the fact that some of the fields for this rotation can be prepared for the cropping scheme earlier than others, it is not always practicable to have the initial crop follow in any regular order in adjacent fichs. Thus in fields $\mathrm{H}, \mathrm{I}, \mathrm{K}, \mathrm{L}$, and $\mathrm{M}$, the rotation, as stated, begins with

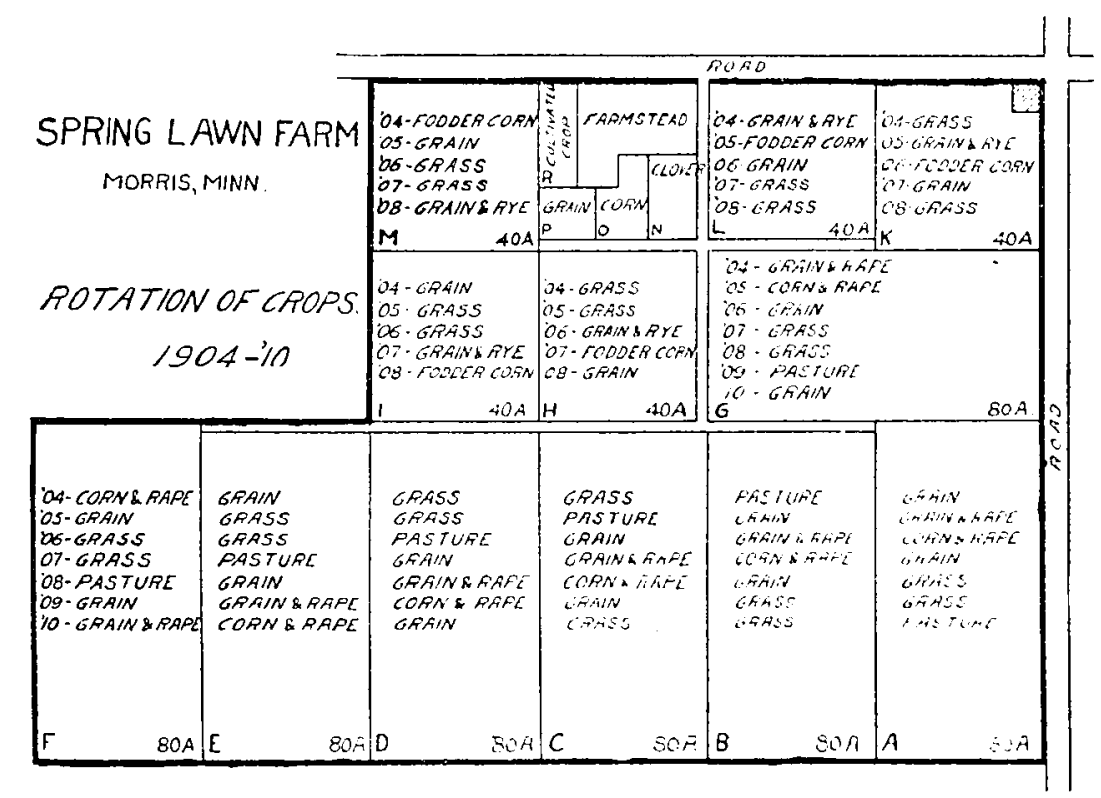

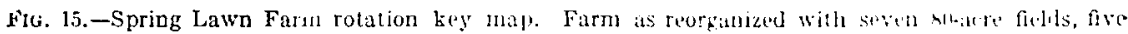

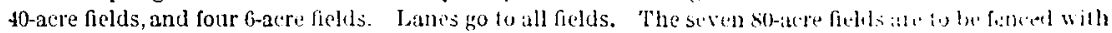
a combination of barbed and woven wire, one birbed wire above and two belus a 2t-ind bithon of

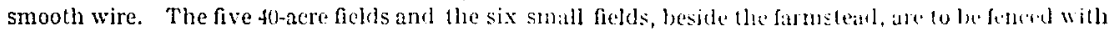
a 50 -inch ribbon of 12-strand woven-1yire fencing, with one barbed wirc below.

The rotation on the seven s0-acre ficlds is: First yen (manured), com and rape; secomd year, frain (t pounds red clover, 2 pounds alsike, and 8 poumds timothy seeded with the spring yrain); thind amel fourth years, meadow; fifth year, pasture; sixth year, grain; and seventh year, grain and rape. But three fields are to be plowed each year, the field for corn and two ficls for gritin. One fieth of grain is suwn on disked com land.

The rotation of the five 40-acre fields is: First year (mantured), corn; second year, fuan jolus 4 pounls red clover, 2 pounds alsike, and 8 ponnds timothy; third year, meadow; fourth ytar, flicture; and tifth year, grain. But two of the fove fields are plowed encli yeat, one for corn and one fur grain. The coun land is disked for giain.

The rotation of the four 6-acte felds, near the buildings, designed to supply asily aressible pasturuge and soilage, is as follows: First your (manurw), corn or other cullivated (rop, as protatous or duangels; second year, fodder corn; third year, grain; and fourth year, clover. But three fields are pluwed each year.

grain in 1904 on field I; in 1905 on field M; 1906, ficld I; 1907, fieht $\mathrm{K}$; and 1908, field II. This sequence may be shown by arrows leading from the crop used as the initial crop of the rotation and from the field on which the crop is grown each successive year, as in figure 8 . 
The four 6-acre fields, N, O, P, and R, besides the farmstead, are to be planted to a four-year rotation; First year (manured 10 tons to the acre), corn; second year, grain; third year, clover; fourth year, cultivatud crops, as potatoes, roots, and corn.

Figure 13 shows the transition plan adopted in 1902 for Spring Lawn Farm, to be used for that year with the old field lines, for the most part, still remaining. The crops, however, are planted with relation to the future lines of the fields, as shown in figure 15 , that

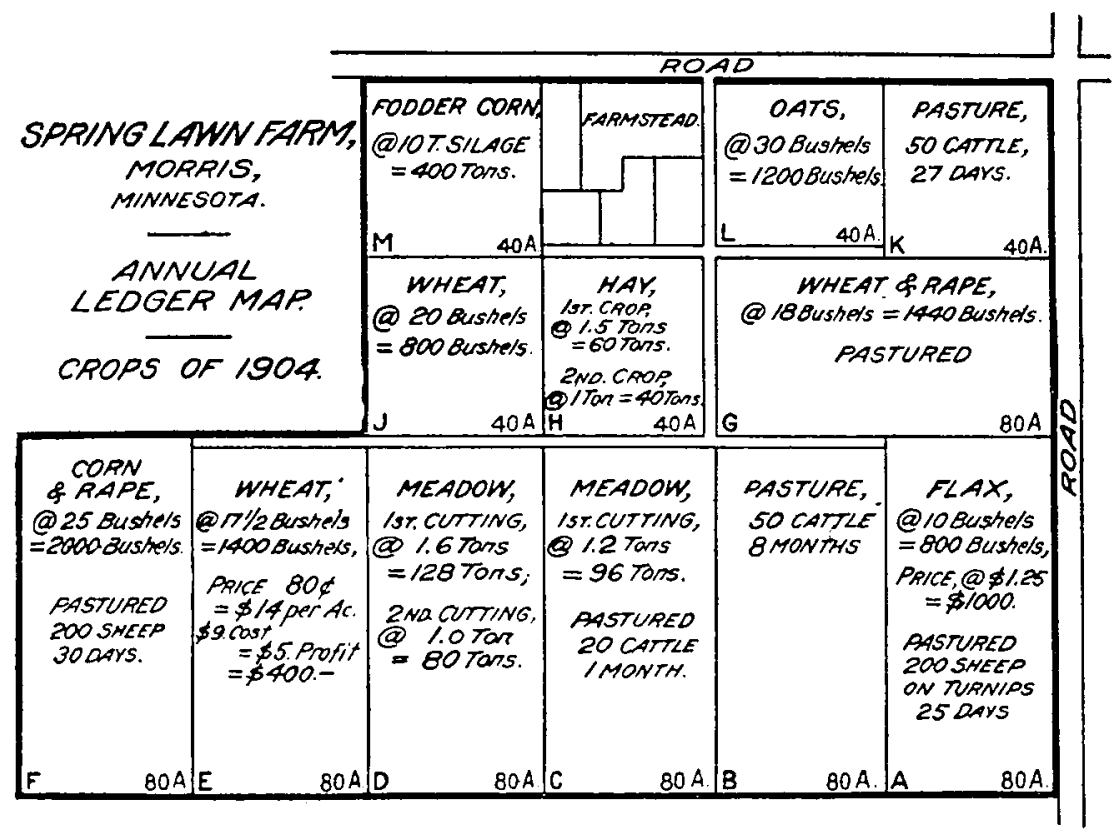

Fig. 16-Spring Lawn Farm. General annual ledger data, by fields.

the land may be uniformly prepared on each respective field for the crop which is to follow. Under this plan all native hay land is to be broken this year.

In figure 14 is shown the transition map of this farm as planned for 1903.

The purpose carried out in the new plan, projected on the key map in the figure 15 , is to secure wheat, flax, or other small grain from two of the three s0-acre ficlds and from one of the 40-acre fields, also some timothy and clover seed, and to use the corn, the pasture, the hay, stubble, straw, and other roughage, as well as some of the small grains, in the production of cattle, hogs, and horses for sale. It is designed gradually to develop a business in pure-bred live stock and in pure-bred seeds.

Each ficld should have a permanent name or number. Letters generally best serve the purpose because they are simpler to place 
on the maps and on tabular statements. Thus, on the key map the letter used as the name of a field can be placed on the lower lefthand corner and the figures representing the acreage, followed by the letter $A$, can be placed in the lower right-hand comor.

It is sometimes convenient to desimnite cach rotation and the fields it occupies. Thus, on Spring Lawn Farm the three rotations may be designated as the 7 -ycar, the 5 -year, and the 4 -year rotations. On a farm where there are two t-year rotations each rotation can be given a number; thus, rotation 1 and 2 , or hetter, a proper name, thus-grass rotation, grain rotation, or other name suggestod by some permanent feature in the rotation scheme, often the name

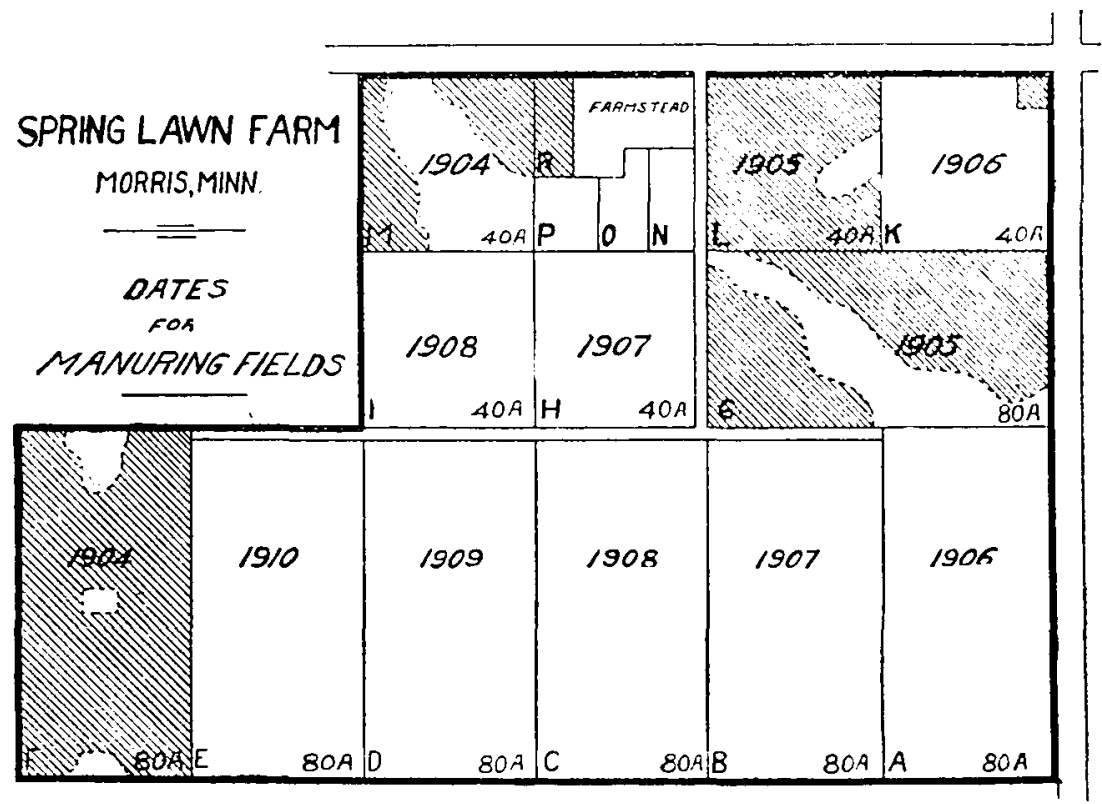

F19. 17.-Spriag Lawn Farm. Manuring schedule shown by dates in each field; also showing the bightr places in fields where manure has been actually placed. A new blank must be used as often as the shortest rotation is completed.

of the principal product sold, as wheat rotation or dairy rotation. On a farm where the rotation is centered about the production of potatoes that rotation could be known as the potato rotation. A temporary rotation to rid the farm of quack grass or other persistent weed might be known as the weed rotation.

\section{FARM PLANS MADE BY STLDENTS.}

Below are given plans of 17 farms made by students, in each case presenting the farm as it was before reorganization and the projected plan for reorganization. These are chosen to show typical farms and to demonstrate the fact that most Minnesota farms are not well 
organized and that far better plans can be made. These specifie problems were chosen from those presented by students in the classes in farm management in the St. Anthony Park Agricultural Ifigh School and in collegiate rlasses in agriculture at University Farm, and were selected from plans marle between the years 1000 and 190 ;. 'To save space and avoid repetition, the students' notes and instructor's eriticisms have been cut down to those features needed to describe the drawings or to bring out only the leatures presented in the successive steps. Each student was expected to discuss his own furm in full from the stanrlpoint of the various features mentioned throughout all these statements.

Only in rare cases, where the farm was very irregular or where there were many things in a state of transition, was the student baffled, and the only help needed was a general start at a scheme of planning the farm. Not only the boys but the girls also usually found no serious difficulty in making rood paper plans of their home farms. In many cases the students were able to consult with their fathers and finally to make plans in which the judgment of the student and parent were combined and to which the teacher could give assont.

Students from the city, and especially city girls, could do little with this subject, sharply illustrating the value of the wirle experjence anined by the farm youth. No case has come under the author's attention where a student experienced in country life or a teacher who has really entered into this work has failed to become enthusiastic over the possibilities of improving the plan of farming through the better arrangement of the farm.

It is found that persons trained in the mechanical or engincering side of this question can greatly assist the farmer in getting his own knowledge and illas of his own farm conditions systematically arranged by moins of drawings and tabular statements, and so recorded that they will he fully understood and may rearlily be folfownd through a long serites of years, and that permanency of plan may he established in his farm business.

Firrures 15 to 59 give phans showing the students home farms as drawn by the pupils during their first year at the St. Anthony Park Agricultural IIigh School. Also, key maps projecting the reorganization of these same farms under systems of rotative cropping and livestock production, projected permanently forward, are shown. Students receiving a series of lectures on farm manisument and fich crops, acrompanied by the required work in making plans, following the scheme outlined above, have been quite as uniformly successful in securing creditable pass marks for work of this kind as for any 
other studies in the curriculum. The teachers have thus been able to demonstrate that the subject of farm management may be successfully taught in the first years of a high-school course to farm youths who have had a practical farm experience.

The instructions to students given above are to be followed by each student in preparing plans for class work. The several plans presented by each student may be graded under such a system of letters or numbers as the teachers may choose for other exercises. Since these plans serve to test the students' general comprehension of the philosophy of farm management and also to test their accurate knowledge of the practical application of farming, they, including the written statements accompanying the drawings, may properly serve as a large portion of the term tests in work of this sort.

\section{STUDENTS' FARM PLANS.}

\section{BLUEGRASS FARM.}

\section{[Statement of Chas. E. Grannis, figs. 18 and 19.]}

Bluegrass Farm is located at Vernon Center, Blue Earth County, Minn., and contains about 160 acres, including the railroad which runs through it. It has been rented for many years and is not in as good condition in regard to drainage as it should be. The house is not used at present. The barn and granary are used for storing hay and grain. There is a good grove, and the orchard still produces a moderate amount of fruit, although the trees are getting rather old. The permanent pasture is a strong feature of the place. Since it is rather low, the soil always contains plenty of moisture. It is a bluegrass and white clover sod and holds up with surprising persistence in the driest weather. During the summer of 1892 it pastured about one head per acre, and there seemed to be plenty of feed. The cattle pass under the railroad through the creek at $\mathrm{X}$, indicated in the plan. There are but two places on the farm which are too wet to be plowed, and these are cut for hay, the grass on them being of good quality. They can be drained very cheaply, however.

\section{IHE PROPOSED PLAN}

Under the new plan (fig. 19) the tillable land is divided into four 32-acre fields, on which a 4-year rotation will be run as follows: First year, corn; second year, barley; third year, clover; fourth year, oats. The fields are larger than can be manured every 4 years, and hence the manure can be applied each year to 16 acres, or one-half of the field that is in corn. Thus, for example, during the winter and spring of 1903 the north half of Field A will be manured; in 1907, when the same field is again in corn, the south half will receive manure. Thus the land will all be manured once in 8 years. Since each field raises a crop of clover every fourth year, the clover and the manure should keep up the productivity of the soil.

By fencing the four fields, A, B, C, and D, rape can be sown with the grain crop each year, and some pasturage can be secured from the clover field. The 64 acres of supplementary pastures will thus yield good pasturage every year. Plans are under consideration for changing the location of the farmstead, as shown in figure 19. 
INSTRUCTOR'S CRITICISM.

The character of the soil should be stated, also the kind and amount of live stock kept. The rotation plan is feasible. Better results might be secured were you to transpose the oats and corn, thus planting corn instead of oats on clover sod. However, if you experience difficulty in getting a catch of clover, your plan may be the better,

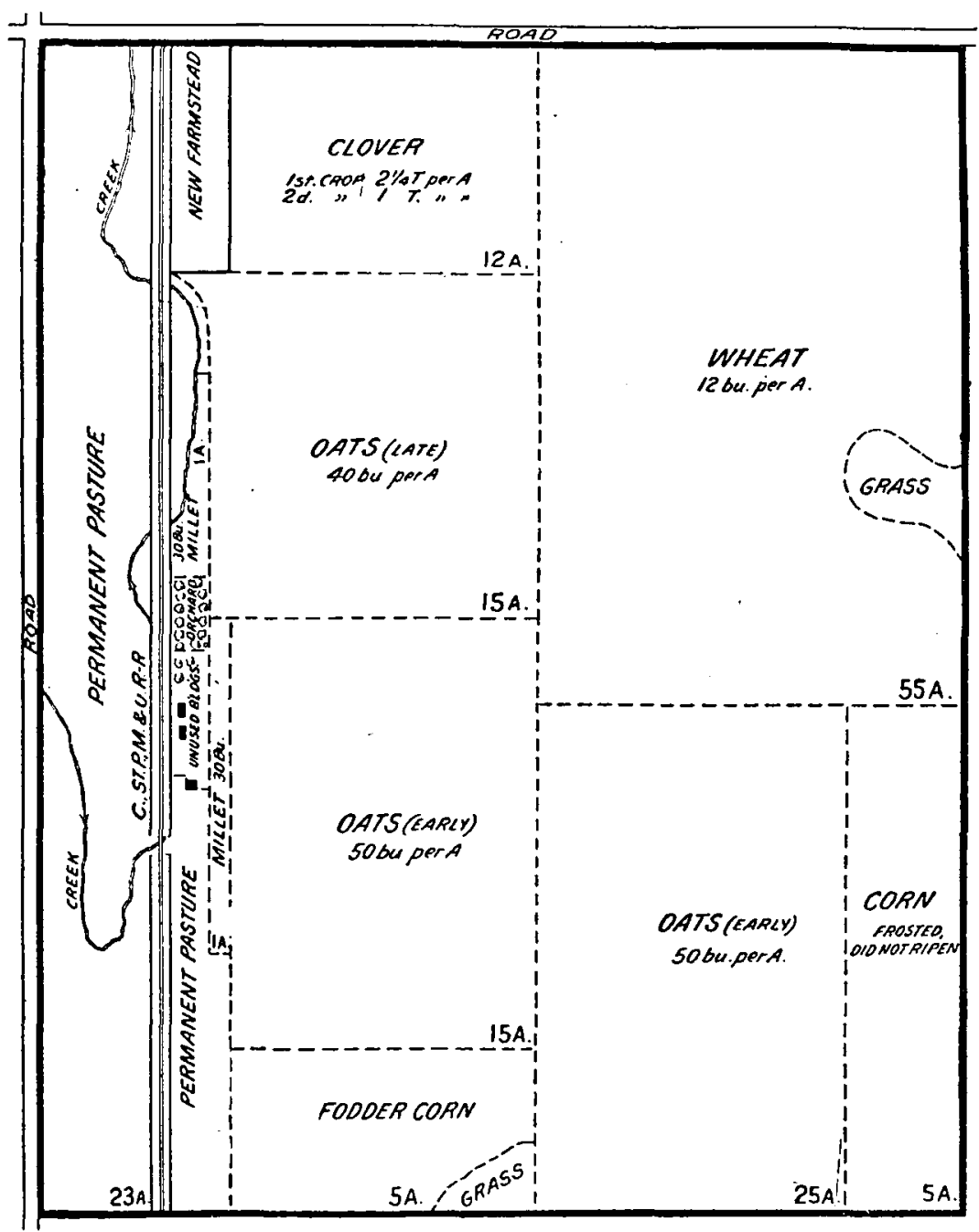

Fig. 18.-Bluegrass Farm. Original plan.

as with your arrangement you seed down with the barley following a crop of corn, which gives a better seed bed in which to get a catch of clover. As you have the arrangement, your difficulty will probably be in the oats lodging when sown on the clover sod.

The 30 or 35 head of stock which can be pastured on the permanent pasture, supplemented by catch crops in the rotation fields, are needed to keep up the productivity 
of the 4 fields. This number of live stock would produce enough manure to cover 1 of the 4 fields each year with a dressing of from 8 to 10 loads per acre. Manuring every 4 years and the crop of clover will increase the productivity of the soil, permitting you to sell some grain as well as live-stock products.

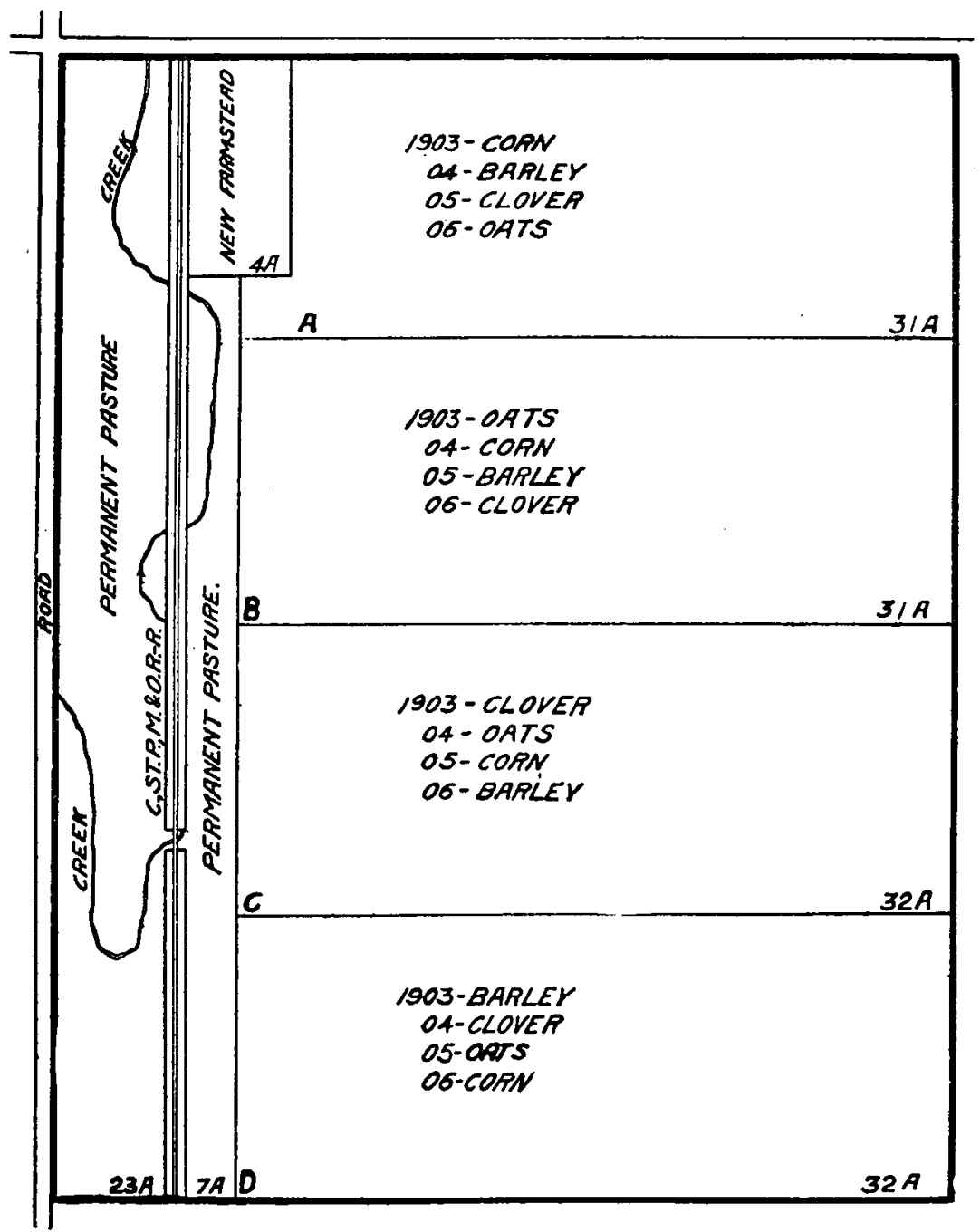

Fic. 19.-Bluegrass Farm. New plan.

\section{Powell Farm.}

[Statement by Leonard Powell, figs. 20 and 21.]

This 280-acre farm is located near the town of Marshall, in Lyon County, Minn. The fields are nearly level, the wetter land sloping enough toward the west so that all waste water is carried away by a large open drain. The small sloughnear the barn can easily be drained by running a tile drain to the public road, then westward about 30 rods. The buildings are a good house, a horse barn, granary and cattle shed, hog house, and sheep shed. The line of farming carried on has been that of grain raising and stock 
feeding, the wheat and flax being usually sold soon after thrashing, while the barley, rom, and oats are fed on the farm.

The live stork kept, are cattle, horses, sheep, and swine, the horses being raised only for carrying on the farm operations. About 75 head of cattle are kept the year round and fed for becf. Somewhere near 400 head of sheep are bought in the fall and pas-

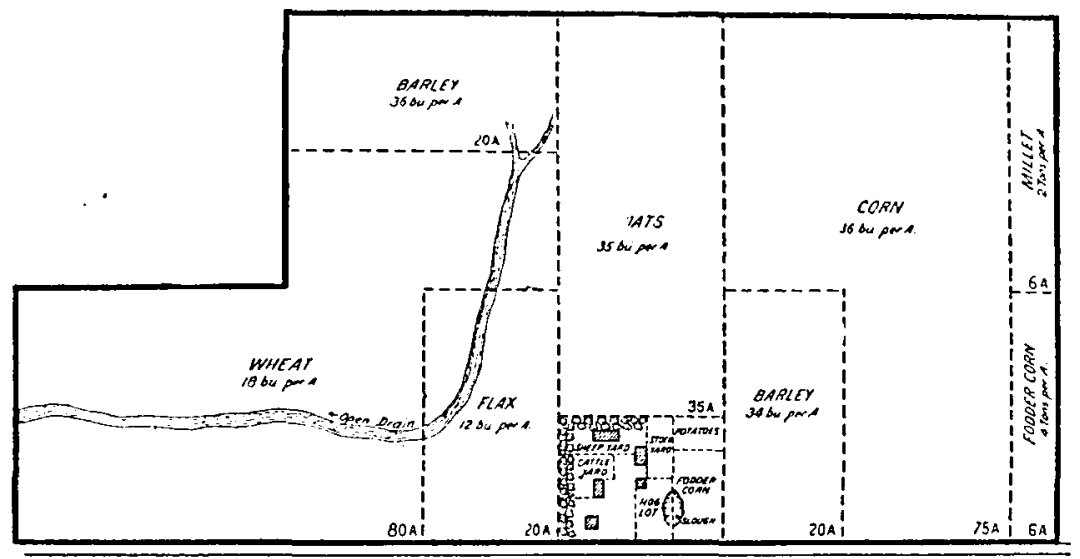

FrG, 20.-Powell Farm. Original plan.

tured on the stubble fields, enough corn and mill stuffs being fed also to put them in good market condition after a short period of yard feeding in the late fall. One hundred head of pure-bred Poland-China swine are raised each year, the best being sold for breeding stock and the remainder fattened for market. The farming operations require about 12 head of horses.

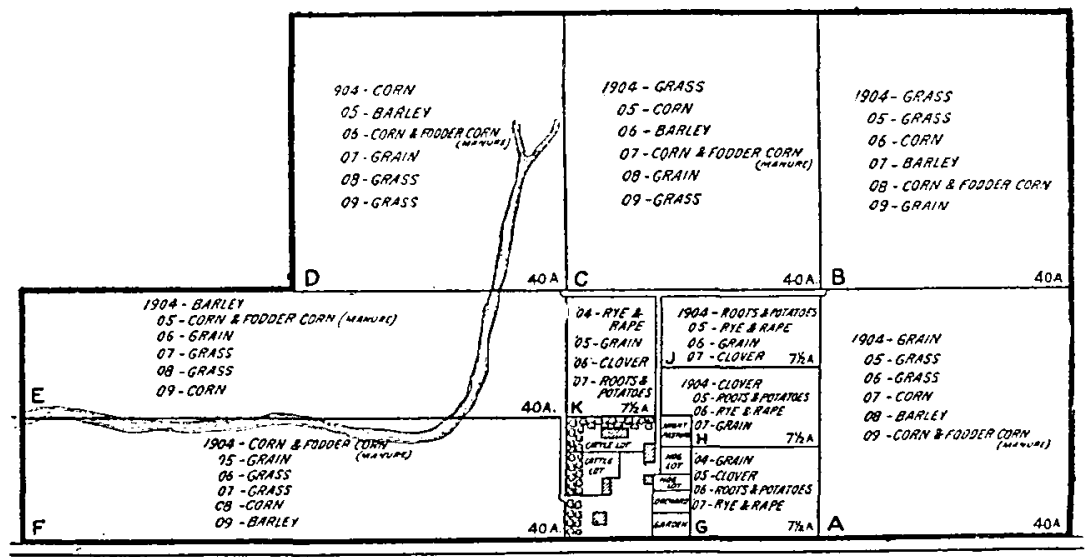

Fig. 21.-Powell Farm. New plan.

THE NEW PLAX.

No definite rotation has ever been followed, as shown in figure 20 . In the proposed new plan shown in figure 21 the fields are slightly altered for 1903 , so as to bring the farm into a definite 6-year rotation in 1904, with six 40 -acre fields of equal size. The rota- 
tion provided on the 6 fields is as follows: First year (manure), corn; second year, grain; third and fourth years, grass; fifth year, corn; sixth year, grain. It will be noticed that the 6 fields used for the larger rotation are so arranged as to reduce the cost of fencing almost to the minimum and so that each is easily accessible from the buildings.

The 40-acre field from which the farmstead is deducted is divided into four equal plats, upon which a minor rotation is to be grown for hog pasture, root crops, and similar uses, the rotation being: First year, grain; second year, clover; third year, roots and potatoes; fourth year, rye and rape.

\section{INSTRUCTOR'S CRITICISM.}

Your plan appears feasible, except that you have not provided enough pasture for the amount of live stock you are planning to keep. You have provided 80 acres of

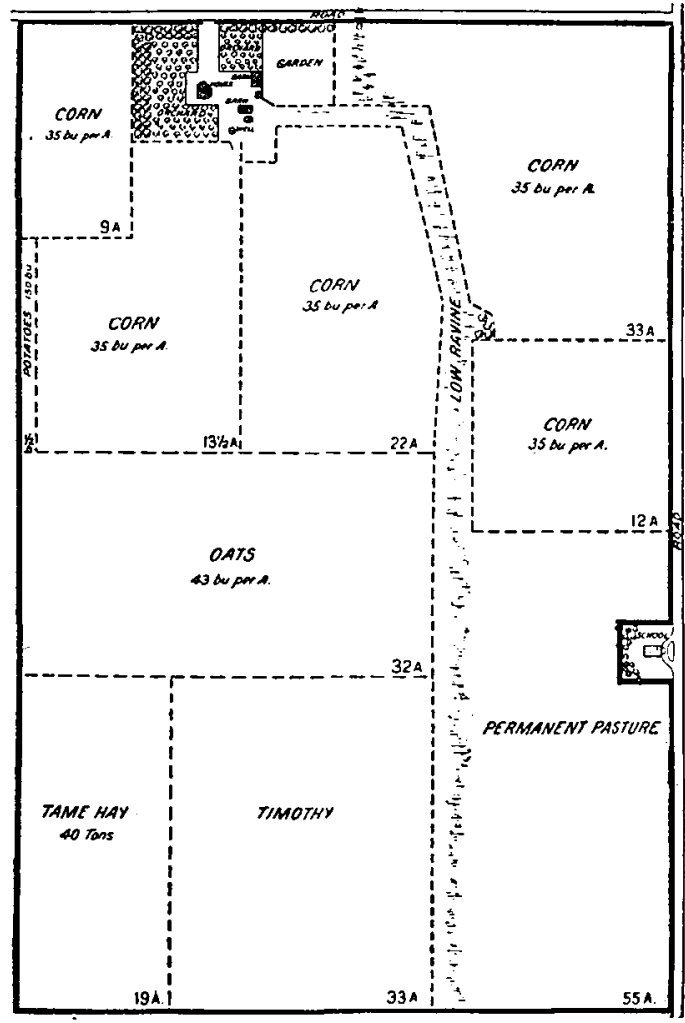

FIG. 22.-Keogh Farm. Original plan. grass in your 6-year rotation, presumably 40 for hay and 40 for pasture. You have provided $7:$ acres of rye and rape and $7 t$ acres of clover in your 4-year rotation. You can plant rape among your corn and barley and even aniong your corn and fodder corn, thus making much tame pasture in your 6-year rotation. The alternative would be to let the grass lie 3 years and then choose for the sixth field as to whether it should be in corn or barleyor o ther grain, or part in corn and part in grain. Your 6-year rotation would thus be stated as follows: First year (manure), corn and fodder corn; second year, grain; third year, fourth year, fifth year, grass; then corn or grain. Your statement indicates that you have been keeping considerable stock, but your original plan does not show pasture for a sufficient source of roughage for so large a number of animals.

The arrangement of the fields in both rotations is good. You fail to state whether the open ditch is such that you can conveniently work across it or must turn at the ditch. The fields might be more conveniently worked if a tile drain were practical unless you can work across the open ditch.

Since it will not always be practicable to sow rye following roots and potatoes in your 4-year rotation, corn and rape may be substituted for rye and rape. It will be observed that you can easily replace part or all of the roots and potatoes with corn and rape. These fields of corn and rape can be profitably hogged off. 


\section{KeOgh FARy.}

[Statement by G. F. Keogh, figs. 22, 23, and 24.]

This 240-acre farm, situated near Le Roy in Mower County, southern Minnesota, is all tillable, except a low wet ravine running through the farm lengthwise, as indicated on the maps. The land is rich and in good farming condition. The place is well equipped with buildings for hog and cattle raising, which is the main line of farming carried on, the grain products being fed on the farm. About 200 hogs and 25 to 30 steers are fattened each year and considerable breeding stock is kept. No rotation has been followed, part of the farm being sowed to permanent pasture; the fields near the buildings have been planted to corn so that they might be partially pastured, and the farther fields have been planted to grain and hay. (See fig. 22.)

THE IEW PLAN.

A j-year rotation is planned, however, beginning with 1905 on five 30 -acre fields, and a 4-jear rotation on four 5-acre fields, as shown in figure 23. One intermediate year will be required in order to get the grass in the right fields in both rotation schemes. The larger fields are divided as nearly equal as possible and the low ravine is used for a lane for stock and vehicles between fields. This lane is wide enough so that one can drive on either side of the wet ground, and the idea is to pasture it that the use of the land may not be lost. The main rotation consists of: First and second years, corn; third year, oats; fourth and fifth years, grass. The minor rotation of four $\overline{5}$-acre fields is planned for summer pasturage for hogs until the corn is ripe, when they can be turned into coru in one of the large fields. This rotation is as follows: Firstyear, corn; second year, potatoes; third ycar, roots; fourth year, pasture, the manure to be applicd to the pasture.

\section{ISTRLCTOR'S CRITICISM.}

The major rotation is very grood both in arrangement of fields and system of cropping. The use made of the ravine is excellent. The minor rotation is poorly arranged. The fields are rather too small for the number of hogs proposed to be kept and the cropping system is not well suited to your needs. You are planning to grow three cultivated crops in succession with no crop with which. toseed down for pasture. This would necessitate using annual pasture crops which are expensive to grow and not as much benefit to the soil as clover. Five acres would not thus furnith sufficient pature for 200 hogs. Four ninor rotation fields should contain 
8 or t0 acres. Your rotation might be arranged on some other plan. Would suggest that. you set aside 40 acres for your minor or hog rotation, as shown in figure 24 . On the four 10-acre fields the following four-year rotation would be suitable for your purposes: First. year, grain; second year, clover; third and fourth years, corn and rape to be hogged off. If desired, part of the land assigned to corn can be used for such annual pasture crops as rye followed by rape. The 10 acres of clover would furnish much pasture for the hogs. The 5-acre, three-cornered strip across the ravine from the farmstead might be seeded to alfalfa or other crop for soiling. Two 35-acre fields on the east side of the ravine and three 32 -acre fields on the west side might be used for the same 5-year rotation for which you planned.

'It is not wise to try to raise hogs without ample pasture, as pasture greatly reduces the cost as does also the hogging off of corn. As three of these fields, one for clover

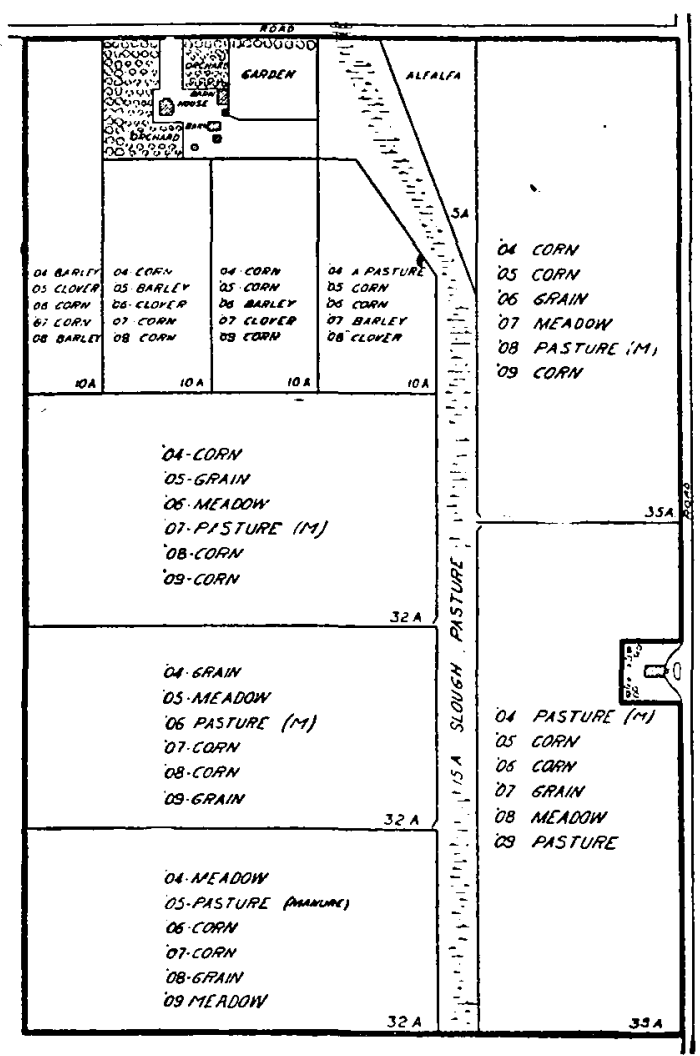

F1G. 24.-Keogh Farm. Rerised plan. and two for corn, will be pastured each year, good use will be returned for the expense of fencing these four fields.

\section{LAKESIDE FARM.}

IStatement ly Robert L. Ott, figs. 25 and 26.1

Lakeside Farm consists of about 160 acres situated near the city of Albert Lea in Freeborn County. This land is touched by two railroads, one passing the southeast corner and one running east and west, cutting the farm in to two parts. The tillable land is all tile drained, as indicated in figure 25. The land marked pasture is rather wet and allowed to grow timber. The farm is well supplied with buildings, ronsisting of a house, barn, granary, hor house, henhouse, woodshed, and machine sheds. Diversified farming is followed and proves quite profitable, both grain and animal products being marketed. Considerable live stock is kept the year around, 20 head of milch cows are kept and about 30 head of steers are fed each winter. A number of hogs are marketed each year; the corn crop, which is the largest crop, is mostly fed on the farm: Only enough horses are kept to carry on the farm work.

\section{THE PROPOSED ILAN.}

No definite rotation has been followed. An attempt has been made to kill the quack grass in the southwest corner by continuous cropping to corn. For this reason a year will be shipped before the proposed rotation is started. A 6 -year rotation is planned, as shown in figure 26 , on 6 fields of 20 acres each. Fields $A$ and $J$ are to be cropped as one of the fields of the 6 -year rotation. The rotation is to consist of: First 
year, corn; second, third, and fourth years, grain; fifth and sixth years, grass. The minor rotation is to be carried on on 3 plats of 5 acres each and will be used entirely for hog pasture as each crop comes into season. Cattle can reach the lake from the farmstead by passing under the railroad track just west of the farmstead.

\section{INSTRUCTOR'S CRITICISM.}

The plan shown in figure 26 is quite feasible. The form, size, and arrangement of the fields are as good as possible under the conditions: By pasturing the 20 acres of grass the second year, together with the permanent pasture and catch crops, suffcient pasture may be supplied. Twenty acres of hay and 20 acres of grass and stubble would hardly furnish the roughage for all the stock you are planning to keep and it

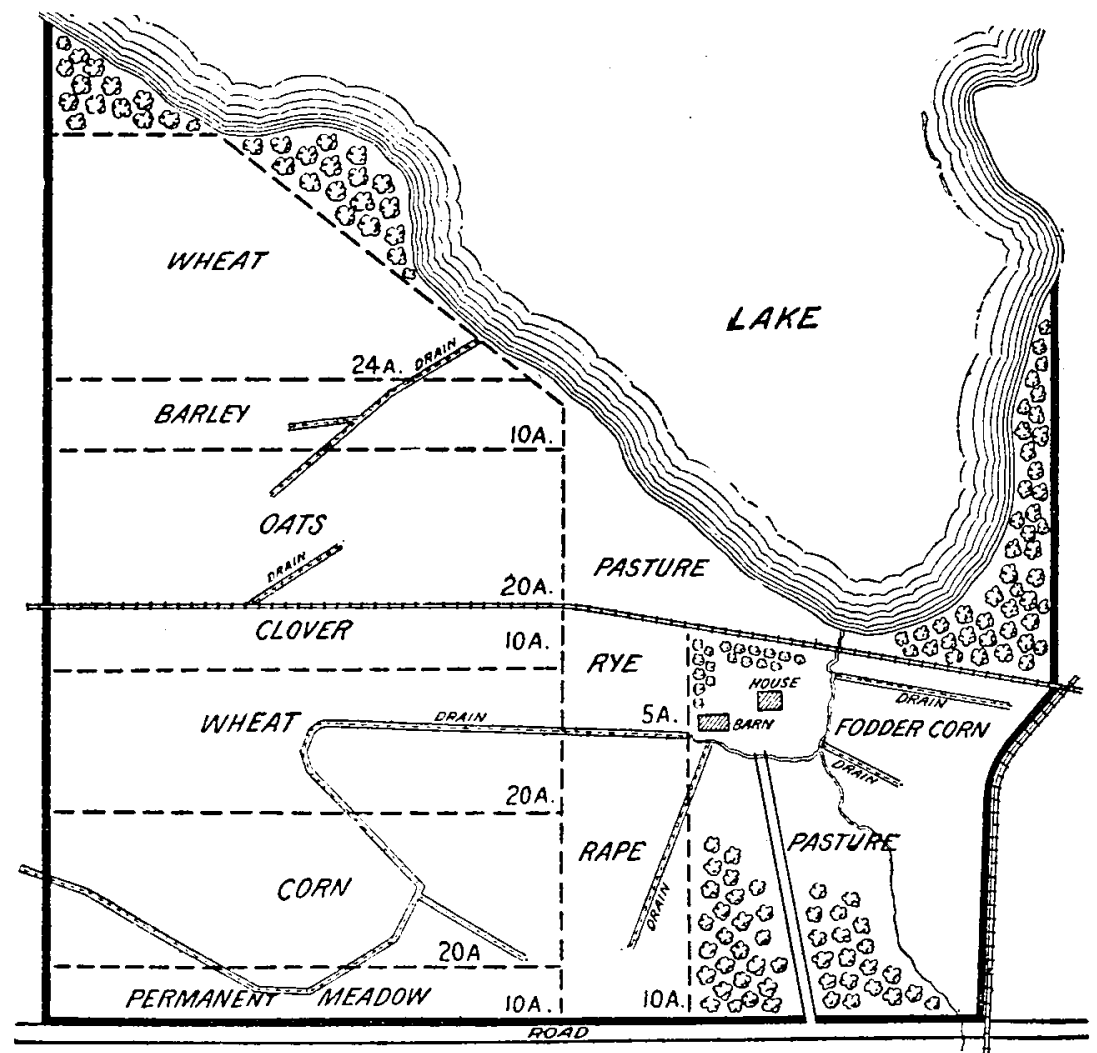

FIG. 25.-Lakeside Farm. Original plan.

may pay, at least in some years, to allow the grass to lie another year, thus reducing the amount of land for grain. Or, since you have abundance of manure, it would pay to replace one of your grain crops with ear and fodder corn. Would suggest the following 6-year rotation: First year, corn on grass sod; second year, oats; third year, (manure) corn; fourth year, wheat or other grain; fifth and sixth years, pasture. Some of the annual product of manure can be used as top dressing on the pasture.

Should you care to practice hogging oft corn you might change your three fields to four fields of about 4 acres and substitute the following 4-year rotation: First year, grain; second year, clover; third year, corn and rape; fourth year, corn and rape. Tnder this plan you would use your hog fencing three years out of four and thus get much pasturage 


\section{Martingon Farm.}

[Statement by II. R. Martinson, Ags. 27, 25, and 29.]

The farm of 160 acres shown in figure 27 is situated 2 miles from the town of Sacred Heart, Renville County, Minn. The public road runs through it north and south, separating the two eighties. The land is all tillable, though a few acres would be benefited by tile drainage, they being somewhat wet in the spring. These fields can easily be drained at small expense. The buildings are fairly good and consist of a house, barn, and granary.

The old style of grain farming has been gradually replaced by diversified farming, the soil having become so impoverished by the production of wheat and flax that a change was necessary.

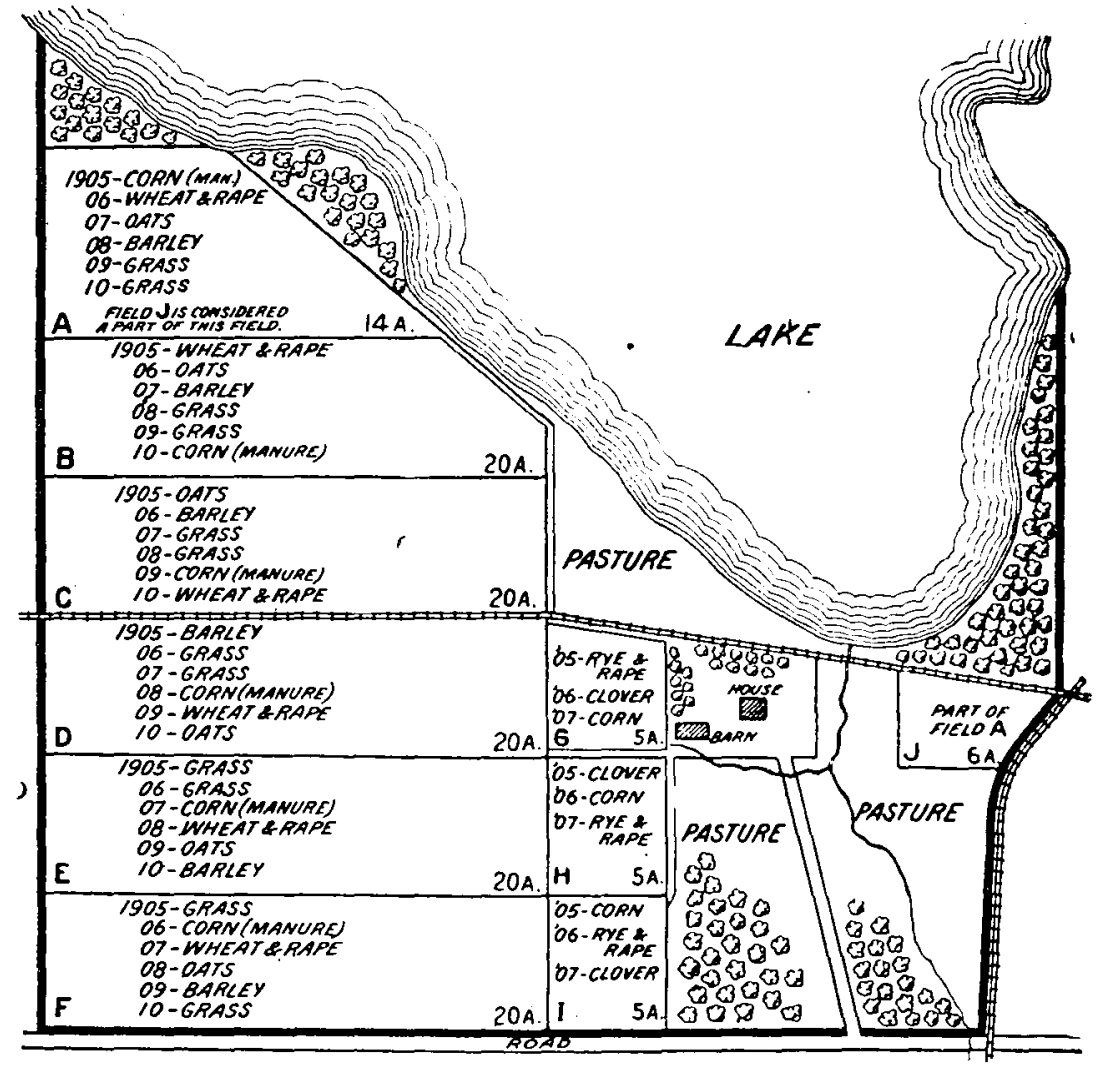

Fig. 26.-Lakeside Farm. New plan.

There is a good creamery in Sacred IIeart, and it has bern found profitable to ktop 15 head of dairy cattle, and 100 head of hogs are marketed each year. Only 5 horses are kept for operating the farm. Nosystem of crop rotation has been followed up to the present time, but for the two years past a large part of the land has been set aside for pasture, grass, and cultivated crops: with a view to getting the soil in better conditiol: for a rotation.

THE NEW PLAN.

As no intermediate state is necessary, the rotation suggested in figure 28 may be started immediately. The farm is divicled into eight 20 -acre fields, one for the farm- 
stead and minor rotation and the other seven for the major rotation, consisting of: First year, grain; second, third, and fourth years, grass: fifth your, grain; sixth year, corn; and seventh year, grain. It is planned to keep enough stock to consume all the products of the farm excepting the flax, which will be sold on the market. The farmstead will consist of 4 acres, and the minor rotation will orcupy four 4-acre fields. These will be used for raising fodder corn and for hog pasturage, under the following rotation: First year, fodder corn; second year, barley; third year, rape; fourth year, clover for hog pasture.

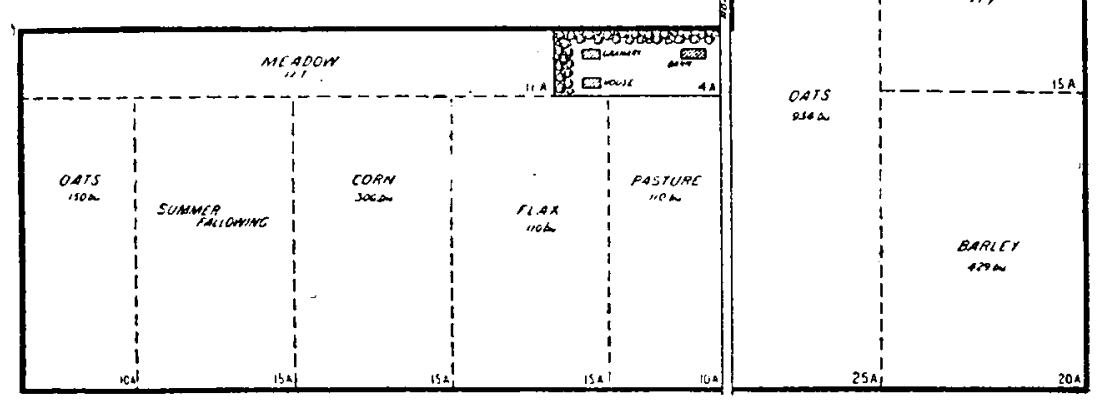

Fig. 27.-Martinson Farm, Original plan.

INSTRUCTOR'S CRITICISM.

Your plan of rotation on the seven 20 -acre fields is good, except that it might be better to transpose the oat and corn crops, letting the oats follow flax and corn follow oats. This would allow you to sow grass sced with barley on the corn land, which is very often an advantage over seeding on fall-plowed grain stubble. It is not clear from your plan how you can get all the fields west of the house seeded and ready for pasture so soon, as some of this land was in corn the previous year and rould not well have been seeded. The arrangement of fields in both rotations can be improved by changing to the plans shown in figure 29 . The form and arrangement of the fields in figure 28

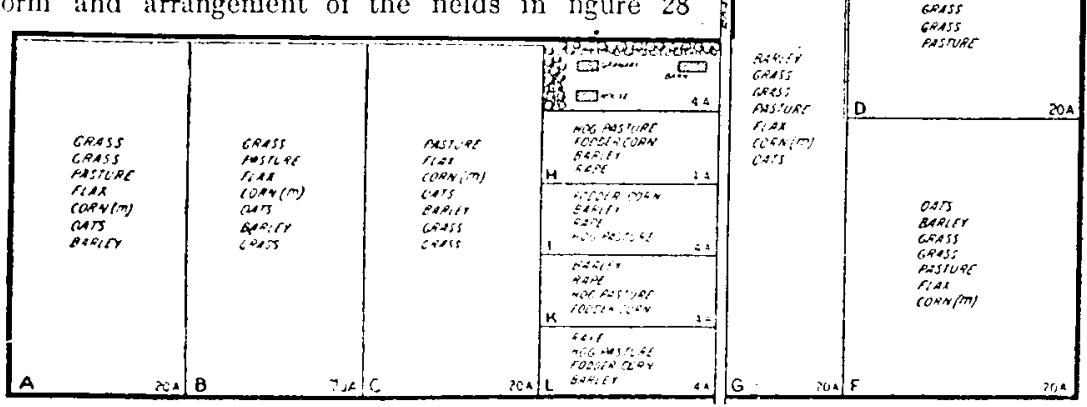

FlG. 2X--Martinson Farm. Student's plan.

make the fields $D$ and F very inconvenimt, and a great deal of time would be wasted in getting to and from them. A large amount of lane fencing is also necessary in getting the stock to and from pasture in these fields, as compared with the plan in figure 29. 
The change in the fields on the west fio acres requires, including the lane, 40 rods more fencing than your plan, but fielul $C$ is is near the farmstead as hefore, field $B$ is 30 rods nearer, and field $A$ is 43 rods nearer. If the number of trips made to one of these fields during the seven years of the rotation were determined and multiplied by 43 rods, the saring made by having one end of the field as near as possible to the farmstead would be apprecirted. It must be admitted, on the other hand, that more transition years will be required to loring the ficlds under the rotation scheme if the change is made according to the plan in figure 2 ?

The minor rotation in figure 28 is pon in grading and arrangement of fields. The advantage of the rearrangement of these fields in figure 29 is very easily seen. You are planning to follow rape with a hog pasture, which of necessity must be of annual crops, which are more costly and less desirable than clover, which ordinarily is preceded by a grain crop. The following rotation is suggested, as in figure 29: First year, grain; second year, clover; third year, potatoes, garden, corn, and rape; and fourth year, corn.

The farmstead should be radically remodeled. The barn appears to stand between the house and the road. This is a most undesirable arrangement, as $\mathrm{i}$ does not allow for barnyards in front of the house or in the grove back of the barn. It also shuts off the view of the road and destroys the possibility of artistically arranging the lawn. The position of these two buildings might properly be changed.

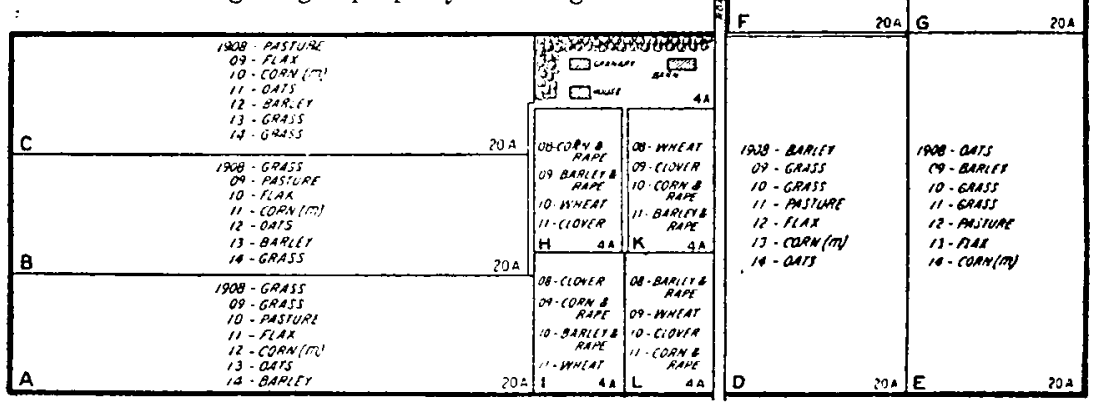

Fia. 29.-Martinson Farm. Revised plan.

\section{('ioverdale Farit.}

[Statement by David Boss, fig. $3 \kappa$

Cloverdale Farm consists of 200 acres; located in central Wabasha County, 5 miles from the village of Zumbrota, on the Chicago, Milwaukee \& St. Panl Railway. The soil is a fairly good clay loam, not sindy or stony, and the farm is fenced on all sides with a permanent fence.

There is provided a 10 -acre permanent pasture about a small lake near the farmstead. Three small 5-acre fields, K, L, Mf, have a 3-year rotation: First year, fodder corn; second year, annual crops for green manure or for pasturage; third year, potatoes, mangels, and other root crops. The four 10 -acre fields, G, II, I, and J, have a 4-year 'rotation: First year, wheat; second year, hay; third year, corn; fourth year, barley. The six 20-acre fields, $A, B, C, D, F, F$, have a di-year rotation as follows: First year, oats and seed down to clover and limothy; second year, hay; third year, pasture; fourth year, corn; fifth year, wheat; sixth year, barley, and apply barnyard manure on the stubble in the fall before plowing

I would plan to keep about 30 to 35 head of cattle. I would not keep over 25 to 30 head of sheep, about 40 to 50 hogs, and 7 or 8 head of horses. If the 20 acres of 
rotation pasture in the 6 -year rotation and the 10 acres of permanent pasture on field $\mathrm{N}$ failed to furnish feed enough, I should take a crop out of the 4-year rotation and seed to some forage crop to use as sheep pasture.

I do not know the average yield of corn, but would cut the corn for ears and stover and feed most of it to live stock. Wheat yields on an average about 12 bushels per acre; 20 acres at 12 bushels equals 240 bushels, of which 45 bushels would be required for seed the following year and about 30 bushels for bread. The remaining 165 bushels would be sold at the average price of about 80 cents per bushel, or $\$ 132 .{ }^{1}$

Barley averages 30 bushels per acre; 20 acres at 35 cents per bushel equals $\$ 210$. I would keep the barley grown on the 10-acre field in the 4-year rotation for feed and seed. Oats average 35 bushels per acre; 20 acres yields 700 bushels, used mostly as feed for live stock, either whole or ground. Hay averages about 2 tons first crop and 1 ton second crop, making a total of 3 tons per acre. The 20 acres yields 60 tons of hay. I would feed this and sell what hay is raised on the 10 -acre field in the 4-year rotation plat. Twenty acres of pasture will support the live stock. I would hope to sell 10 head of cattle each year at an average of $\$ 28$ per head. I would try to sell 25 lambs each fall at an average of $\$ 4.50$ each. Would sell about 30 hoge each year at $\$ 10$ each.

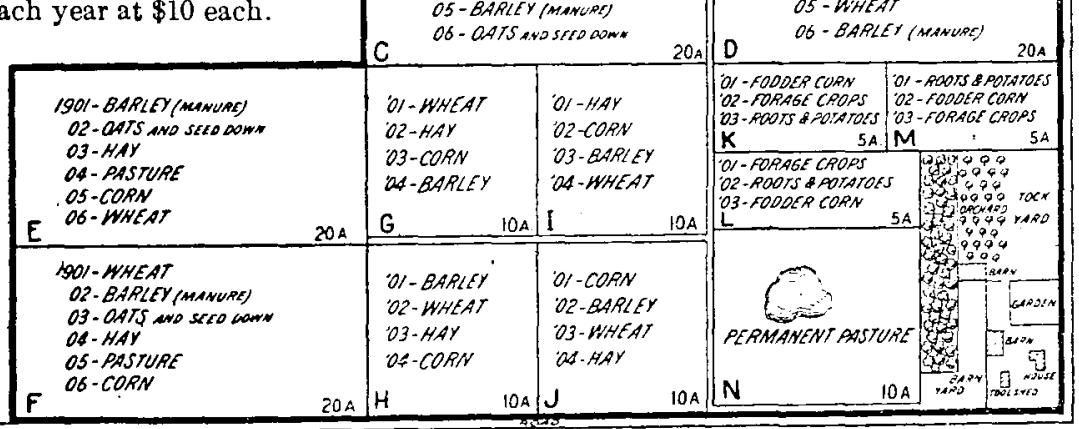

Fra. 30.-Cloverdale Farm. Revised plan.

FOUR-YEAR ROTATION ON FIELDS $(\mathrm{H}, \mathrm{H}, \mathrm{I}, \mathrm{AND} \mathrm{J}$.

1901. The wheat from these 10 acres will all be sold. Twelve bushels per acre is 120 bushels. At 80 cents it equals $\$ 96$, bread and seed having been taken from the 20 acre field.

1902. Hay yields on 10 -acre plat 2 tons per acre. Would yield 20 tons and would sell at $\$ 4.50$ per ton, or $\$ 90$.

1903. Would sell corn from 10-acre field and buy such feeds as bran, shorts, and oil cake for feed. Ten acres of corn, average 50 bushels per acre, gives 500 bushels. This, at 25 cents per bushel, brings $\$ 125$.

1904. Barley on 10 -acre plat yields 30 bushels, making a total of 300 bushels. Would use this for feed and for seed. On the 3-year rotation on fields $K, J$, and I would plan to raise about 3 acres of potatoes each year. Averaging $] 50$ bushels per acre, they would produce 450 bushels. Would use 150 bushels for seed and feed, and the balance of 300 bushels sold at 25 cents per bushel would bring $\$ 75$. The remainder of the 
crops grown on this 15 acres would be used as feed. I would plan to sow rape with wheat, with which no grass and clover are sown, and use it for fall pasturage.

1903, cash received:

From corn on 4-year rotation, field $G$

$\$ 125.00$

From hay on 4 -year rotation, field $\mathrm{H}$

90.00

From wheat on 4-year rotation, field $M$

96.00

From wheat on 4-year rotation, field $B$

132.00

From barley on 4 -year rotation, field $A \ldots \ldots \ldots \ldots \ldots \ldots \ldots \ldots$

210.00

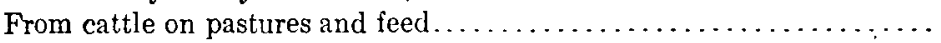

280.00

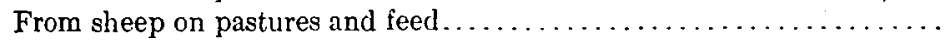

112.50

From hogs on pasture and feed.

300.00

From potatoes on 3-year rotation.

75.00

(Income from cows for milk omitted; poultry and dairy products offset groceries.)

1903, expenses:

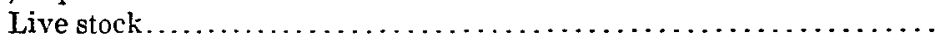

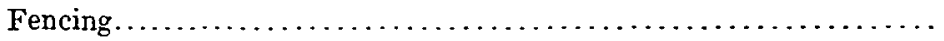

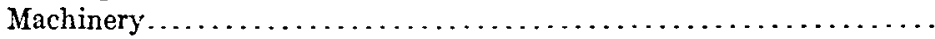

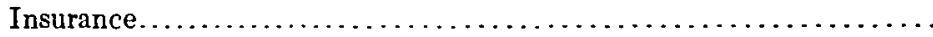

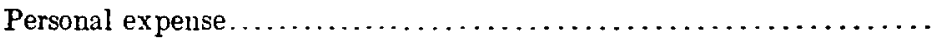

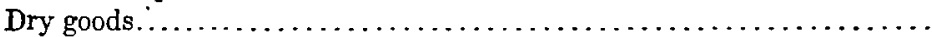

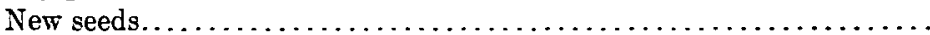

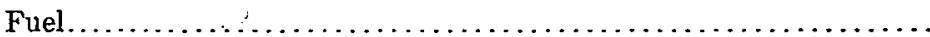

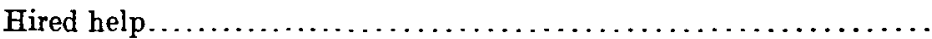

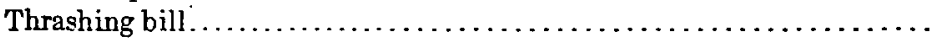

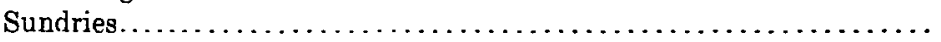

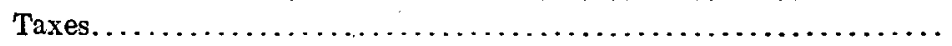

Net gain.

INSTRUCTOR'S CRITICISM.

This description of Cloverdale Farm and farm business illustrates very clearly how easy it is to get a comprehensive iclea of the farm processes or the business of the farm if it is outlined according to some systematic plan permanently projected forward. It is well understood, of course, that there are many conditions which can not be taken into account, such as poor crop years or ravages from insects. Nevertheless, in the long run the man who can obtain as comprehensive a view of his farm as is here indicated has a great advantage.

On the three 5 -acre fields, $\mathrm{K}, \mathrm{I}$, and $\mathrm{M}$, it would seem better to provide pasture crops rather than annual forage crops, which would change the rotation to: First year, barley, seeded to clover; second year, clover pasture; third year, fodder corn and rape. As the 3-year rotation is essentially a swine and forage rotation, it is believed the suggested plan would greatly cheapen the cost of caring for the pigs. The clover will furnish pasture for the growing pigs throughout the season. The rape can be planted with the corn and the corn hogged ofi.

\section{SkOGLUND FarM.}

[Statement bs W. S. Skoglund, figs. 31, 32, and 33.]

This farm is a square quarter section of nearly level land in southwestern Minnesota. Nearly all of the farm is tillable. New buildings are just being put up, as the farm is comparatively new. 
Diversified farming is carried on, considerable attention being given to dairying The live stock consists of 15 cows, 5 horses, 100 chickens, 30 turkeys, 10 hogs, anit 20 head of young stock.

No rotation has been followed, but the fields were laid out last year for a 4 -year rotation as shown in figure 32 .

\section{THE NEW PLAN.}

The 4-year rotatinn gives more grass than needed, so I have changed it to a 5 -year rotation, as follows: First year, corn; second year, oats; third and fourth years, grass;

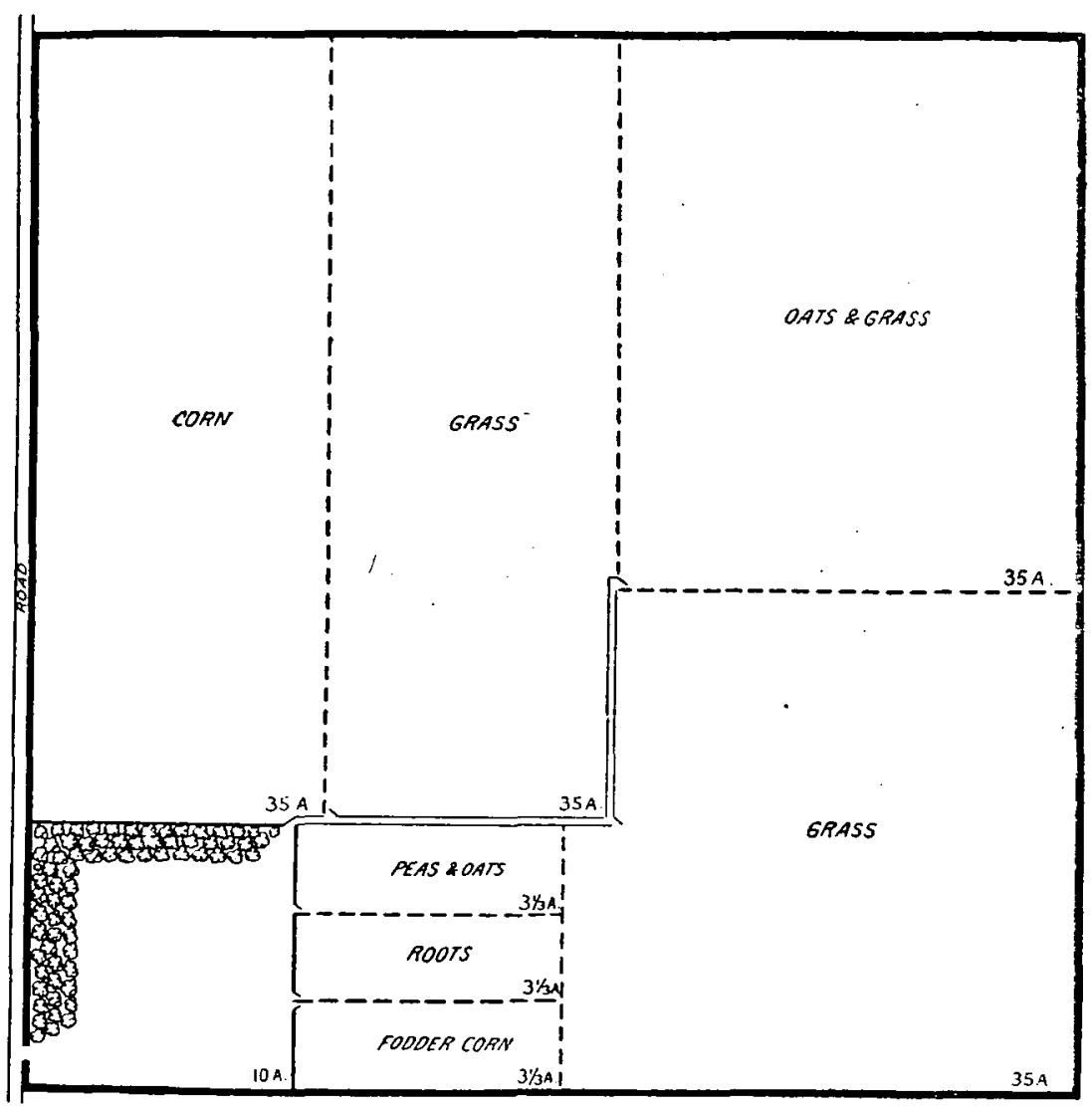

FTG. 31.-Skoglund Farm. Original plan.

fifth year, wheat. One eighty is divided into 3 equal fields and the other into 2 equal fields after deducting 20 acres for farmstead and minor rotation. Ten acres were divided into three equal parts for a minor rotation of: First year, peas and oats; second year, roots; third year, fodder corn.

\section{INSTRUCTOR S CRITICISM.}

Your change from a 4 to a 5 year rotation is wise, and one of these fields in pasture, with catch pasture crops, such as rape, sowed in the corn and oats, will now furnish you ample pasturage. The arrangement of fields, however, is not as good as you might make. Would suggest dividing fields $\mathrm{C}$ and $\mathrm{D}$ the other way, as shown in figure 33 . This would require a little less lane to reach $\mathrm{C}$ and would make the fields more con- 
remient to manure, giving longer bonts with the plow. Would suggest that the oats and wheat be transposed in the rotation, as wheat is a better nurse crop than is oats.

The crops which you propose to grow in the minor rotation are not well chosen. It is impracticable to invest $\$ 100$ in labor and other cxpenses to grow 3 acres of roots. Half that expense will furnish a good supply of-succulent feed and make as much work as you will care to devote to these fields. Would suggest that you add another small field, as shown in figure 33, and make your rotation: First year, oats and peas, followed by rye; second year, corn; third year, grain; fourth year, clover. The clover will furnish pasturage for the hogs much more cheaply than will annual crops, as the cost of production is very much less and the effect on the soil is much better.

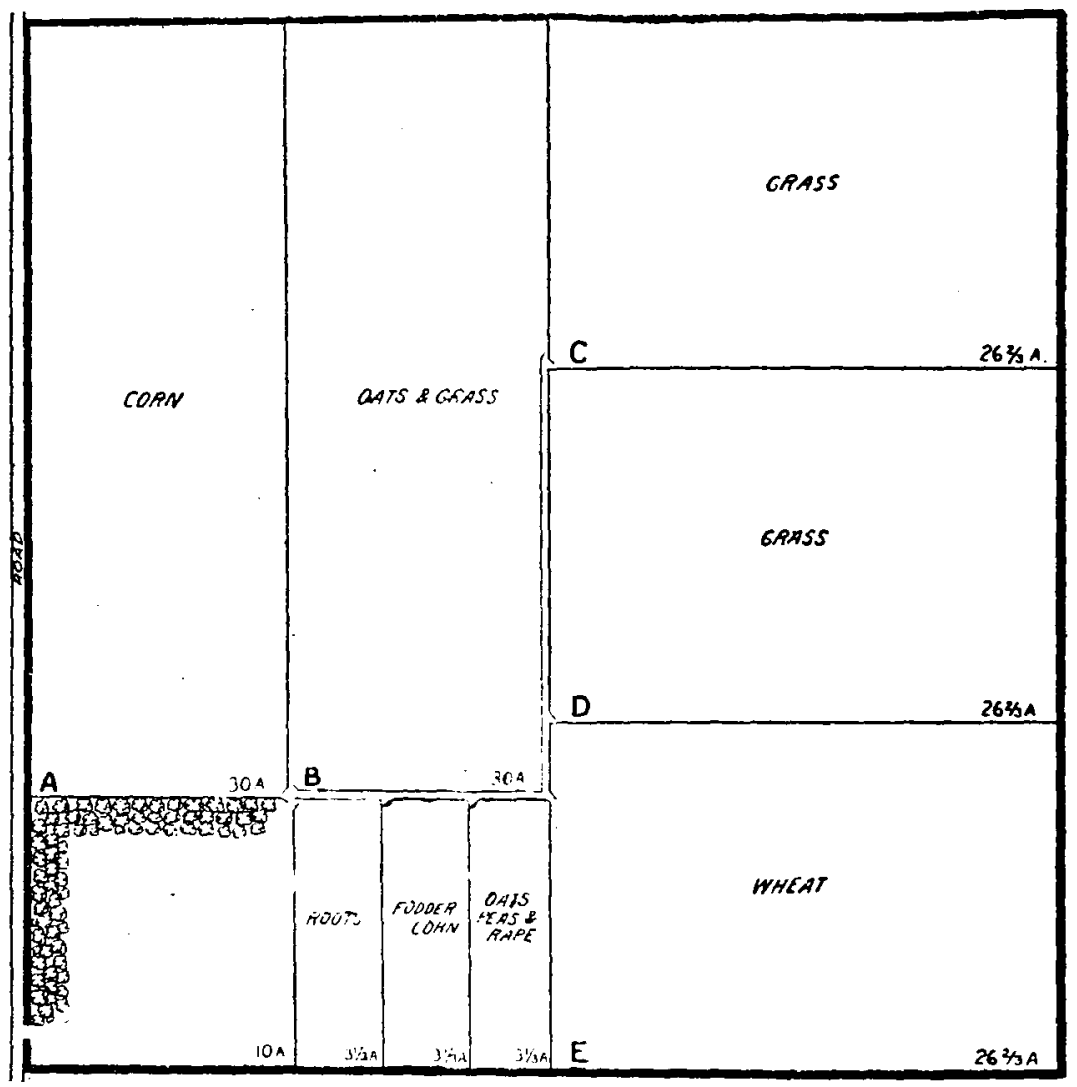

Fo. 32.--Shoghnd Farut. Student's plan.

$$
\text { LAKE VIEW FahM. }
$$

(Statument by Theorture J. Simploun, fig. 34.)

Lake View Farm is situated in the central part of Mecker County, in Greenleaf Township, on the Circat Northern roul, 2 miles mortheast of Star lake creamery and Strout post office. The soil is mostly a light clay, except on some of the hills where there are spots of jellow day mixed with stones. The farm comprises 280 acres. It contains 60 arres of forest, 5 acres of water, and 37 acres of low meadow land; 168 acres are under cultivation, while 10 acres are devoted to farmstead and garden. General farming is practiced, with special attention to dairying. Wheat, fax, mature dairy cows, calves, and hogy will be the principal products marketed. The stock 
kept is nearly as follows: 20 mature cattle, 5 two-year-old heifers, 10 yearlings, 12 calves, 6 hogs, 25 pigs, 6 work horses, and 50 chickens.

A public road runs along the east and south sides of the northwest forty, then turns south, following the west boundary line. A private road rung through the center of the farm and through the farmstead. Permanent lanes run east and west, connecting the fields with the farmstead, as shown in fgure 34 .

\section{THF STUDENT'S PLAN.}

Rotation: The cultivated portion of the farm is divided up into two series of rotation fields. One consists of 8 fields of 16 acres each, $A, B, C, D, E, F, G$, and $H$, and the

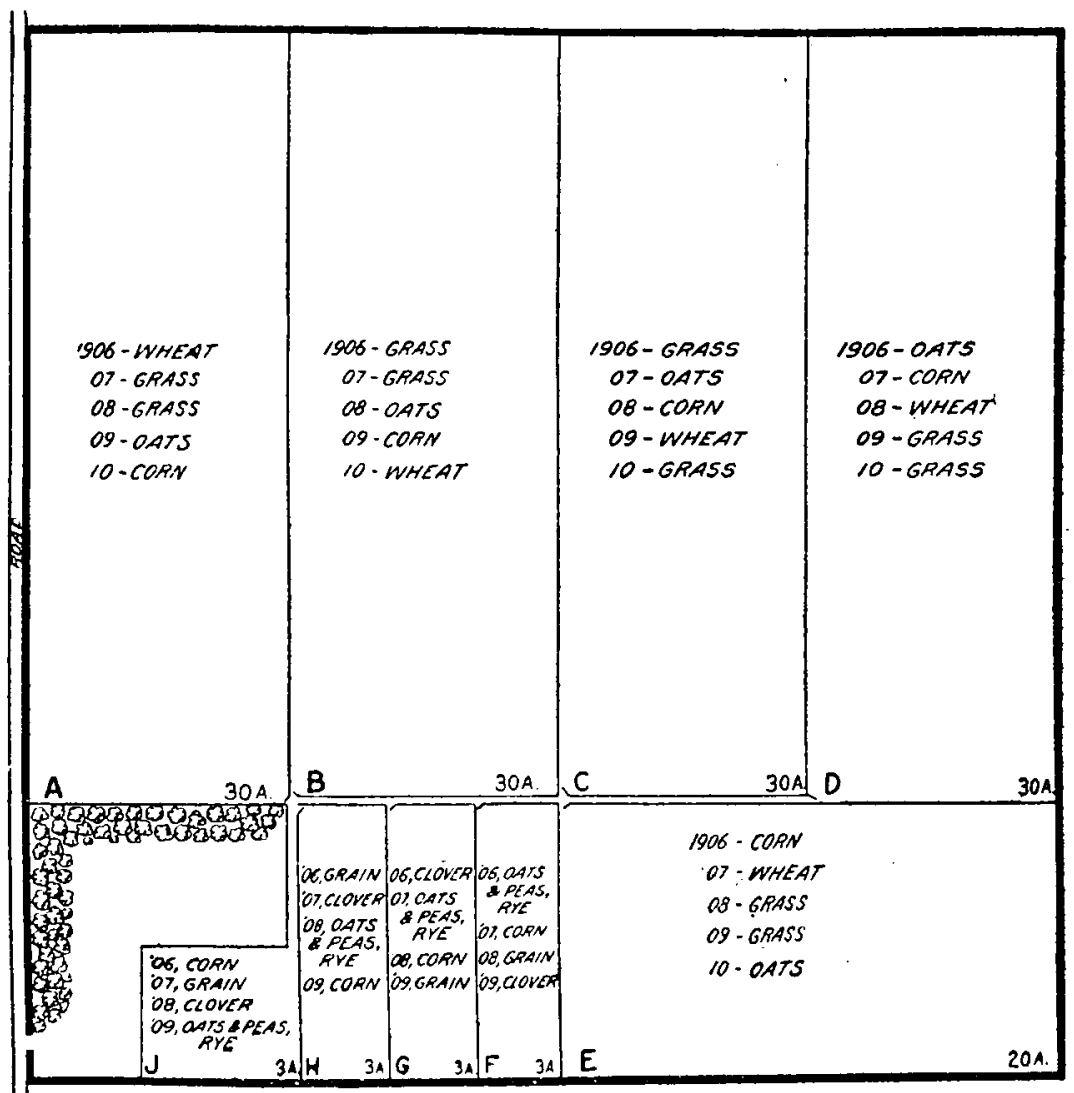

FIg. 33.-Skoglund Fartn. Revised plan.

other of 5 fields of 8 acres earh, $1, J, K, L$, and M. The succession of crops on each field is figured out and shown on the plat. The permauent meadow will not come under any rotation, but will be kept for hay only, and will be fertilized with such well-rotted manure as can be spared from the rotation fields. The rotations have been decided upon in a general way and may be modified slightly as necessity requires. To the rotation for the large fields may be alded rape after wheat for fall pasture. In the rotation on the small fields, where corn is named, part may be planted to potatoes and part to corn folder; and in the fields where small grains are placed. any grain for sale or feed mily be placed.

Permanent fences are maintained around most of the outside lines, along lanes, and around permanent pastures. The rotations are so arranged that, in some cases, temporary fences, located two years in one place, serve nearly all needs. Fields $A$ and 
C being far from the farmsteal can be used for meadow three years, and fiedts $B$ arat $D$ can be pastured two yours each, instead of onc, as indicated, thus avoiding so much change in fencing and at the same time not clisturbing the rotation in the least.

A large open ditch with its branches runing through the lowland on the west hali of the farm drains southwest to Evenson Iake. A ditch on the east side drains the east meadow. Low places in the fields are drained ofi by slough ditches which can be cultivated across. It is impracticable to drain the small marsh in firlel 1 .

IXSTRUCTOR'S CHITISH.

This plan shows a gool example of an s-year rotation where flax fits in well. With 8 years intervening between flax crops there is little danger from Iusess on

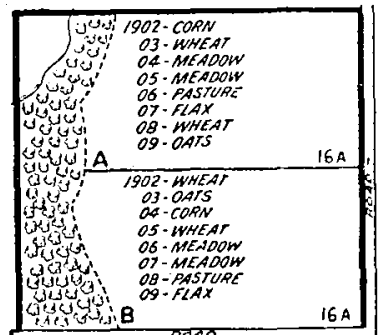
account of flax wilt where reasonable care is taken to secure seed free from llax-wilt spores amol lis trut the seed with formalin solution

In localities where it is difficult lo got at stamel of grass in clroughty gears this longer motation can

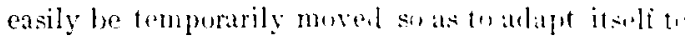

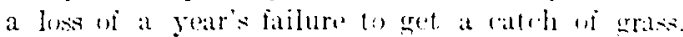
Fur example, if un tield $1^{\circ}$ in 190.5 the grass stand should not be suffi, iently heasy to warrant it bein!

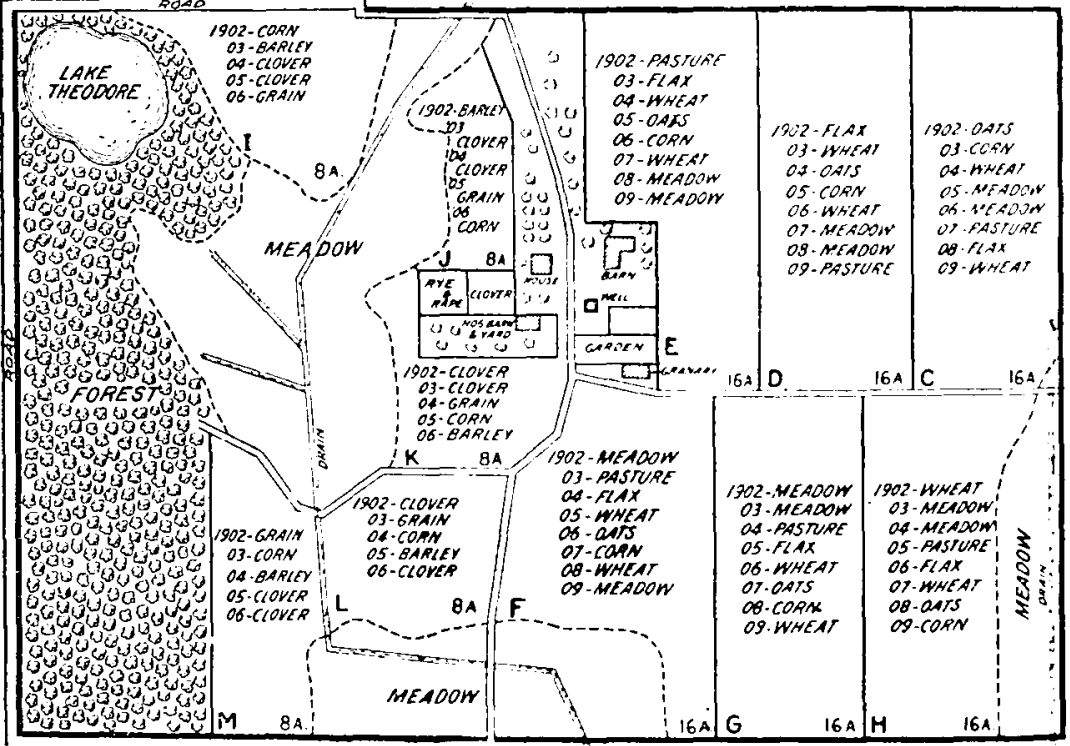

Frg. 34.-Iake View Farm. Reorganized plan.

allowed to remain, it could be plowed up and seeded to flax and the pasture on field G allowed to lie during 190:5 and then be plowed up and seeded to wheat, it. regular crop, in 1906. In field $\mathrm{C}$ the grass could be seeded with the fax, though this is not as good a nurse crop as wheat, and be allowerl to lie 2 vears in grass instead of 3 years. This plan would give flax agrain in 1908 on field ' $'$, but where the land is kept in such condition as this will be by such rotation, and since seed can be treated with formalin, there is no objection to such an occasional change.

The forest contains a great deal of pasture land, which evidently accounts for the small number of acresin rotation grass. Since clover is not likely to live over 2 years in succession, it will be better to sow timothy with the cluver when hay or pasture is 
desired in the 4-year rotation. In case the clover fails, an aclditional grain crop may be grown in one of these 8 -acre fields.

\section{Marple Faris.}

[Siatement by E. F. Marple, figs. 35 and 36.$]$

Marple Farm consists of 320 acres located near Wendell in Grant County, Minn. The public road running east and west cuts off the south 80 and another road running north and south cuts off the east 80 from the 160 on which the farmstead is located. The three forties, extending three-fourths of a mile to the southward from the farmetearl, are mostly taken up with a big dry meadow which has never been broken up. However, the land is all tillable excepting a 5-acre strip on the south end of the east 80 . 1 expect $t o$ kecp on the farm 50 head of cattle, 10 horses, 50 sheep, 4 sows, and 200 chickens. The farm is fairly well equipped with buildings, consisting of a house, woodshed, barn, granary, hog house, and feed house. Lintil a few years ago nothing was raised except grain, but of late years about a carload of cattle are fed each year, and about 50 head of eheep and a few hogs are kept.

THE NEW PLAN.

No rotatica has ever been thought of, but I have planned a 7 -year rotation to be in working order in 1906 (fig. 36). A year or two will be required in which to break up the old meadows and get grass sown in the right fields. The fields will be 40 acres each and will be rotated as follows: First year, corn; second year, wheat; third, fourth, and fifth years, grass; sixth year, barley; seventh year, oats. Forty acres will be set aside for the farmstead and for a 3 -field rotation which is di-

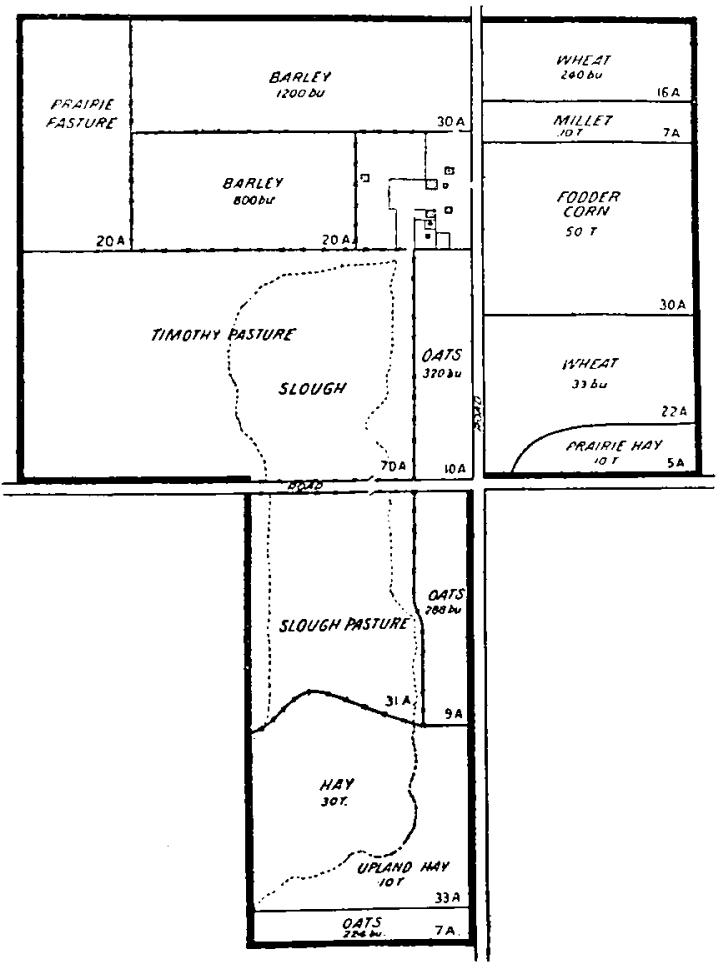

FIG. 35.-Marple Farm. Original plan.

vided as follows: Ten acres for farmstead, and 3 fields of 10 acres each in which the 3-year rotation will be: First year, grain; second year, grass; third year, corn and roote.

\section{INSTRUCTOR'S CRITICISM.}

Flax will often be more profitable than barley following the 3 years in grass. In case it is inconvenient to get stock to the two 40 -acre fields on the south you might pasture them all the time on the farther fields and use all grass on these south felds for hay. Since you have a large farm and presumably use 4-horse machines, it might pay to divide fields $D$ and $E$ and also fields $B$ and $C$ in the other direction, giving longer rounds and somewhat reducing the distance from the farmstead to the fields. In the minor rotation you doubtless mean clover when you say grass. It may pay 
you to replace the fodder corn and roots with ear corn and rape in this 3 -field rotation. You can grow the ronts and fodhler corn neederl in your large rotation so as to hag down the corn and rape in the 10-acre field. As your farm develops in productivity under this rotation scheme you will find that you can keep more live stock, and I suggest that in that case there be al larger number of hogs.

\section{Greaves Farm.}

[Statement by IL. A. (ireaves, figs. 37, 39, and 3?.]

This is a 160 -acre farm situated 3 miles north of Northfield, Rice County, Minn. The public road runs through the farm east and west cutting of the south 40 , as shown in

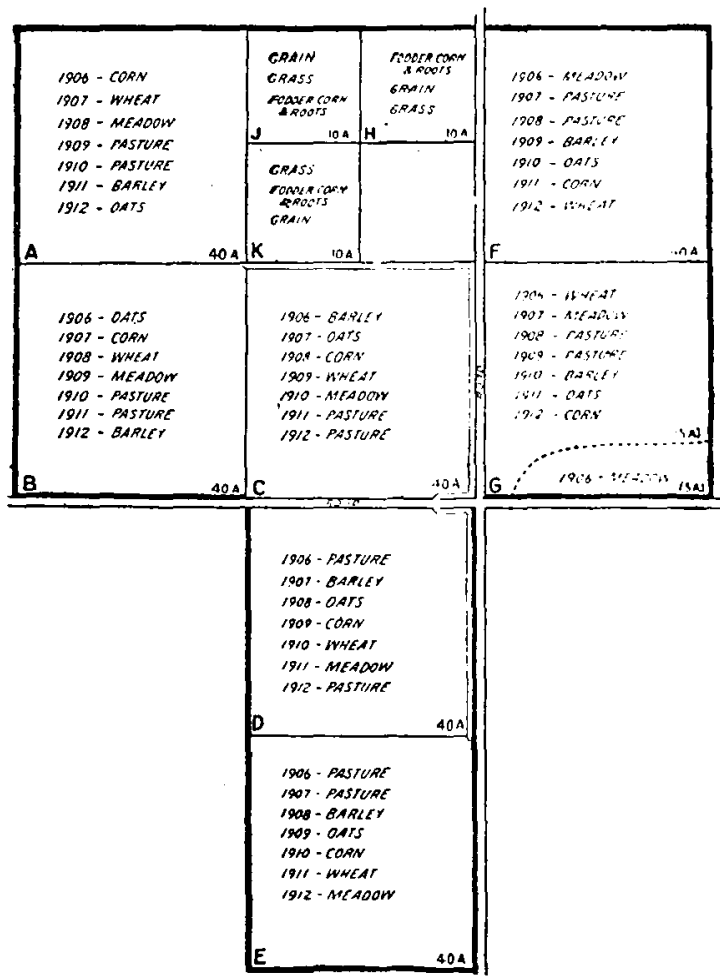

Frg. 36.-Marple Farm. Key inap to student's plan. figure 37 . The land is all tillable cxcepting a small piece in the corner of one of the fields. The buildings (mnsist of a good house barn, granary, and hog house. Dairying is the line of farming followed, all the farm produce being fed on the farm excepting 200 bushels of oals, which amount is uslally sold and the proceeds used to buly cheaper mill stuffs. The stock kept is 30 bearl of dairy cows, 7 horses, and 4 hogs.

TIE SIEW PLAN.

No rotation hasever been followed, but there is nogool reason why one should not be established, and by seeding the 16 acres south of the road to grass in the spring, the i-year rotation given in figure 38 can immediately be taken up. The 7 fields will be 20 acres each, and all are arranged with a view to

being reached easily from the farmstead. The rotation consists of: First ycar, corn; second year, barley; third, fourth, and fifth years, grass; sixth year, forder corn; seventh year, oats.

A 4-field rotation is placed on the 10 -acre plat west of the farmstead and consists of a rotation as follows: First year, millet; second year, sorghum; third year, roots; and fourth year, aweet corn.

Figure 39 shows the use of a blank map as a ledger sheet.

\section{INSTRUCTOR'S CRITICISM.}

The plan suggested is feasible and with a few changes should give good results. Your statement of getting the 16 acres of corn stubble, south of the road, seeded is a little indefinite. However, this can be managed by pasturing as much of the seeded grass land south of the road as needed in 1903; then cut the rest for hay, sow the corn stubble to grain and seed down in 1904; then grow enough fodder corn on some other 
part of the farm to supply the needed roughage. Thus in 190; the rotation can be run regularly as plannerl.

The arrangement of your pasture and meadow sbould be changed so that the firstyear crop is cut for grass, pasturing the second and third years after the grass is better ronted. A little alsike clover seedex with the timothy and red clover will help out the pasture the second and thirrl years. In figure 38 the word "manure" in parenthesis should be before the word "corn " rather than after the word "oats."

If the lay of the land allows, your plan can be somewhat improved by dividing firlds $A$ and $C$ so as to run north and south, having each of these two felds join the filrmsiead, thus making but 40 rods of travel necessary to get to field A.

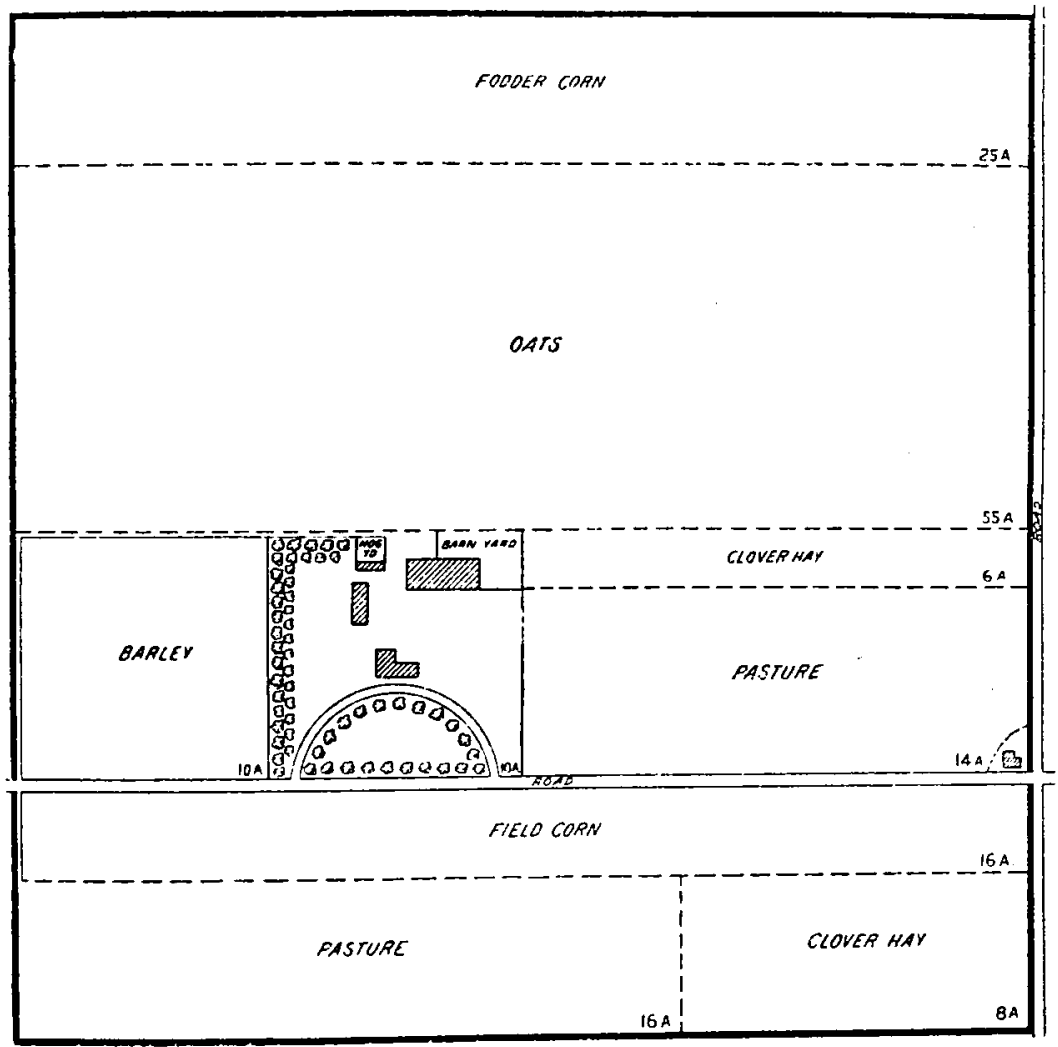

FIG. 37.-Creaves Farm. Original plan.

The arrangement of fields for the 4-year rotation is good but the rotation is poor. You are raising all exhaustive crops. The following rotation would be better: First year, swcet corn; second year, grain; third year, clover; fourth year, potatoes and roots.

Besides the 30 dairy cows you could very profitably keep a larger number of hogs, which this 4 -field rotation would provide with pasturage. By providing acreage for roots and potatoes on the farmstead you could have corn grown for cars sowed in with rape on two of the small fields, which cuuld then he hogged off.

\section{Austronid Farir.}

\section{[Statement by Mr. Austrold, fig. 4).]}

This farm is located in the central part of Pope County, Minn., about 4 miles east of Lake Minnewaska on the southern border line of the town of Glenwood. It contains 560 acres of prairie land, besides having an addition of 80 acres of timber and meadow land which is located about $1 ! 2$ miles west. 
THE NEW PLAN.

To carry out the rotation outlined in the accompanying plan, I intend to have about 80 head of mature cattle, possibly more; no eheep, but possibly a few hoge. Fields in grain and not seeded to grass will be sowed in with rape for fall pasture. Intend to keep about 12 working horses and 2 hired men the year round. The cattle will be grade Shorthorns.

There are 3 sets of rotations to be carried out as shown on the plan: The five fields, A, B, C, D, and E, each containing about 80 acres, will be rotated as follows: First

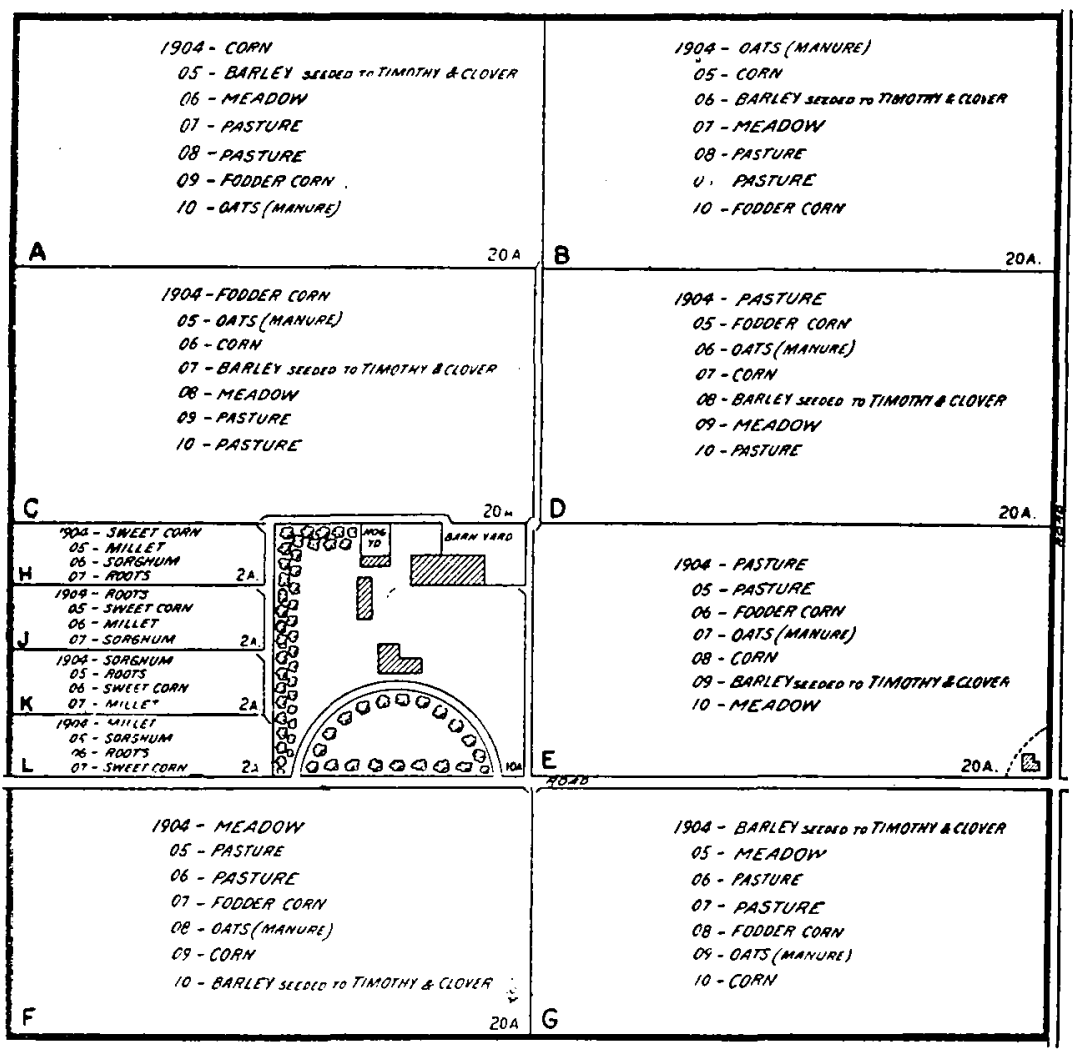

FIG. 38.-Greares Farm. Kev map to student's plan.

year, wheat, second year, clover and timothy meadow; third year, pasture; fourth year, oats and flax; fifth year, corn and fodder corn. The stubble in the field following oats and flax is to be manured for the next corn crop.

The 5 fields, $F, G, H, I$, and $K$, containing about 10 acres each, will be cropped in a 5-year rotation as follows: First year, wheat; second and third years, clover and timothy; fourth year, fodder corn; fifth year, fodder corn. The fodder corn on these fields is intended to be fed out to the cattle as a soiling crop and in this way help out the pastures in midsummer. The manure will be applied before the corn crop. Fields $L$ and $M$ will be rotated with roots one year; barley or some other grain the next rear. $O$ is intended for a permanent horse pasture. 
INSTRUCTOR'S CRITICISM.

This is a good example of careful planning for a farm of this size. But few lanes are proviled and yel every feld can be most conveniently reached, though the farmstead is far removed from the highway. By fencing this farm and sowing rape with the grain crops that follow grass, much pasturage is provided on the 80 -acre fields. The grass the second year would be pastured in most cases. Thus in 1903 field $\mathrm{C}$ would be in pasture and in the fall field $D$ would be in rape. By opening a gate in the

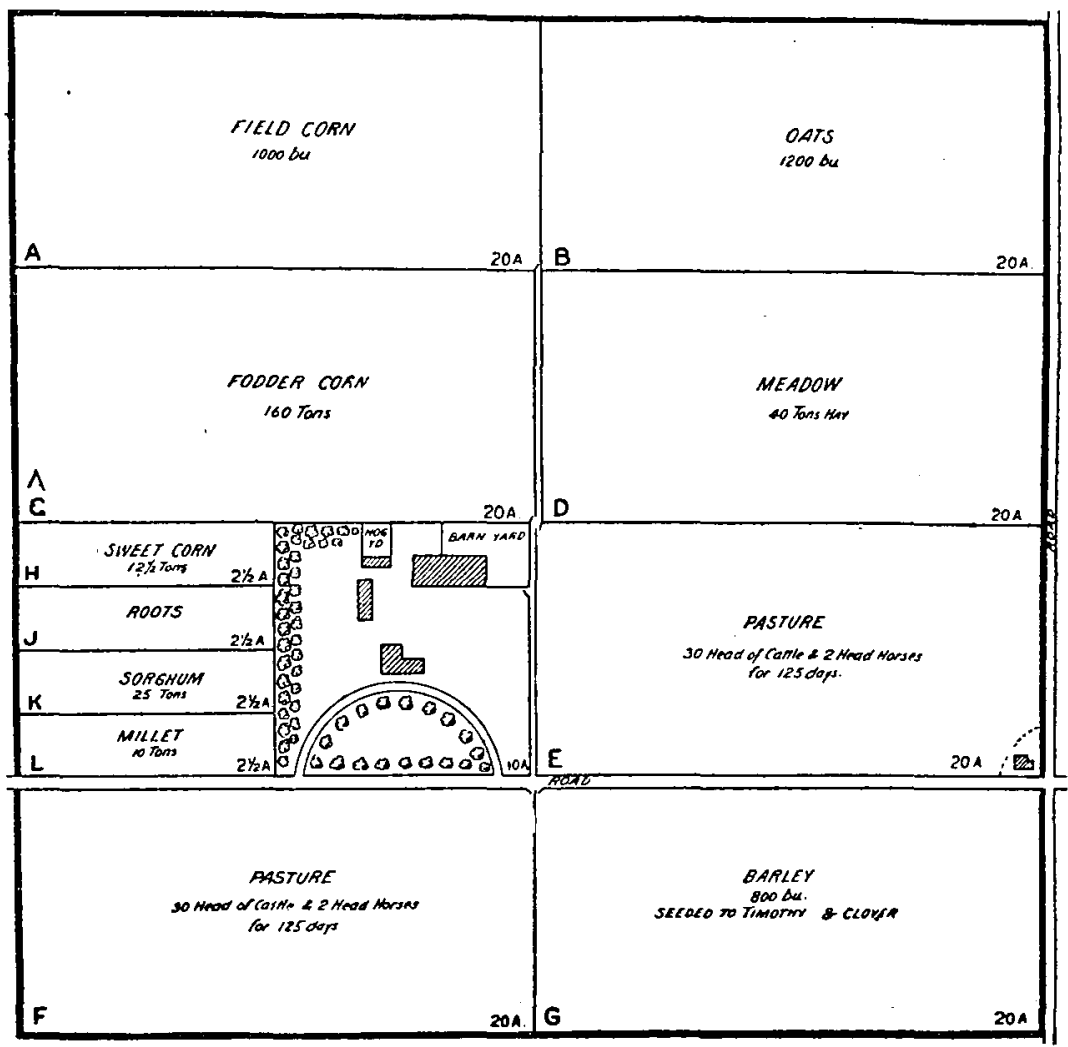

Fig. 39.-Greaves Farm. Key map to revised plan.

southeast corner of field $\mathrm{K} 160$ acres of fields $\mathrm{C}$ and $\mathrm{D}$ are in one field for fall pasture and are connected by a lane with the farmstead. In 1905 the pasturage will be in field $A$ and rape will be in field $B$. In 1906 the rape and grass pasture will be in separated fields; that is, grass in field $\mathrm{E}$ and rape in field A. Again, in 1907, pasture is in field $\mathbf{D}$ and rape in field $\mathrm{E}$. Doublless many low areas about the lakes can be profitably drained.

$16029^{\circ}-$ Bull. $236-12-6$ 


\section{Anthony Farm.}

[Statement by H. H. Mowry, figs. 41, 42, and 43.]

\section{THE GTUDENT'S YLAN.}

This is a 160-acre farm in the Red River Valley and was arranged in 1902, as shown in figure 43. The pernanent pasture in the southwest corner, as well as the outside boundaries of the entire farm, was fenced prior to 1902, as shown in figure 41 . The main crop on this farm has been wheat. In the northeast corner, where it was summerfallowed in 1902, considerable wild oats had gotten in and there are patches of it over the entire farm. In selecting a rotation the problem of checking this weed in

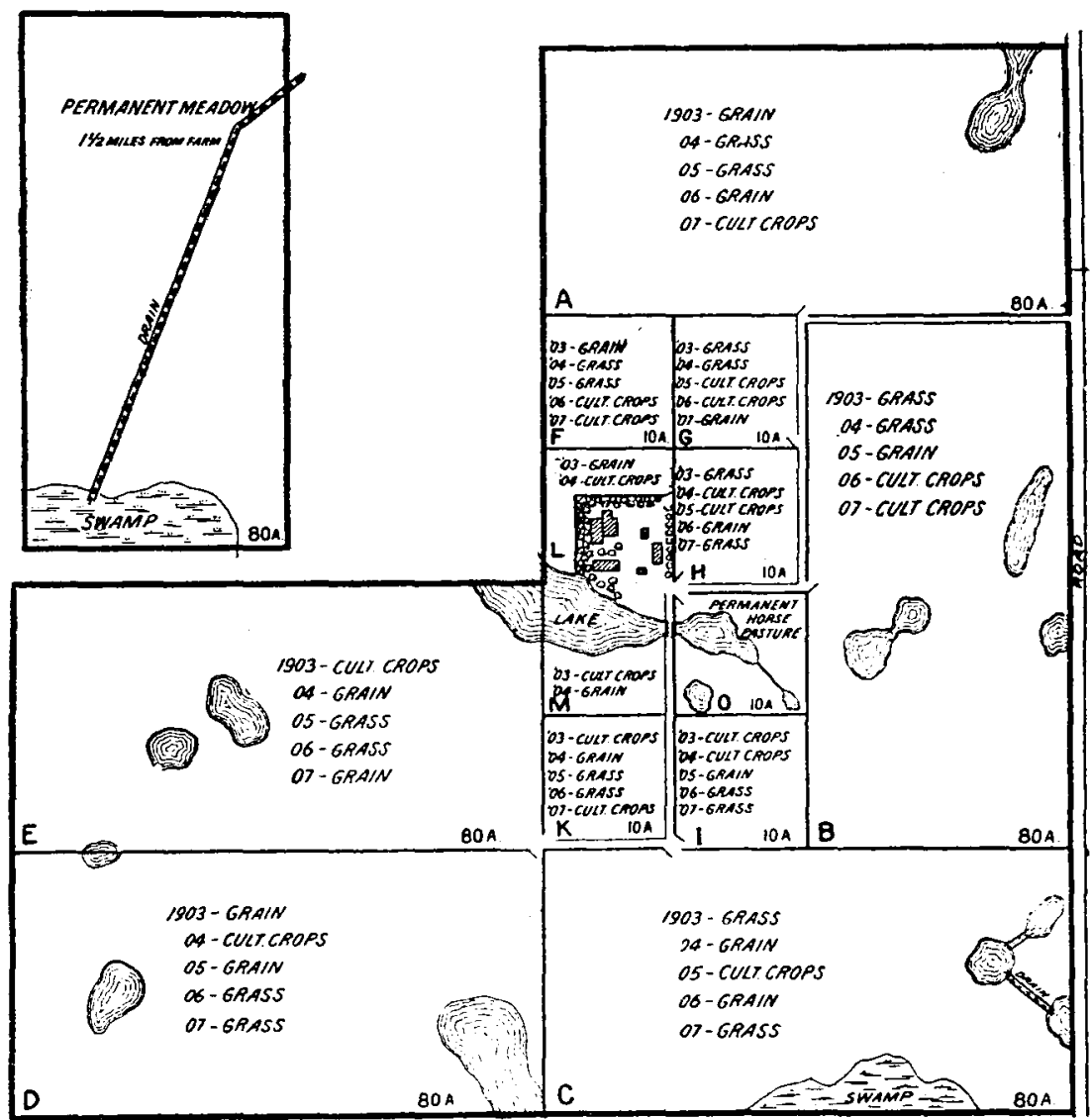

Fig. 40.-Austrold Farm. Key map to student's plan.

particular received consideration, and as the general experience in that country indicates that this can best be done by growing hay and pasture crops, and as it is sometimes difficult to get a stand of grass, an eight-year rotation was chosen in which three years of grass are followed by corn. In the minor four-year rotation the same idea of combating wild oats was kept, in view. In the major rotation a flax crop instead of corn might be profitably raised after the grass crops, provided the land way clean.

The major rotation occupies eight 15 -acre fields, $A, B, C, D, E, F, G$, and $H$, arranged as shown in figure 42 , while the minor rotation occupies the four smaller fields, I, J, K, 
and $L$, containing about 6 acres each. The crops for 1903, not indicated in the rotation plan, which are used in the transition to the permanent rotation schemes, are as follows: Corn to be put on $\mathrm{E}$ to check the wild oats. Fields A, C, and $\mathrm{G}$ are to be put into grass for pasture and to check wild oats. Field $K$ in the former permanent pasture will be plowed up and put into flax. After that the rotation outlined in fgure 42 will obtain.

A lane will be run along the south ends of $\mathrm{A}, \mathrm{B}$, and $\mathrm{C}$, from which $\mathrm{E}$ also can be reached. The other fields can be reached without additional lanes, except a short piece on the west end of $G$, by passing through permanent pasture along the coulee.

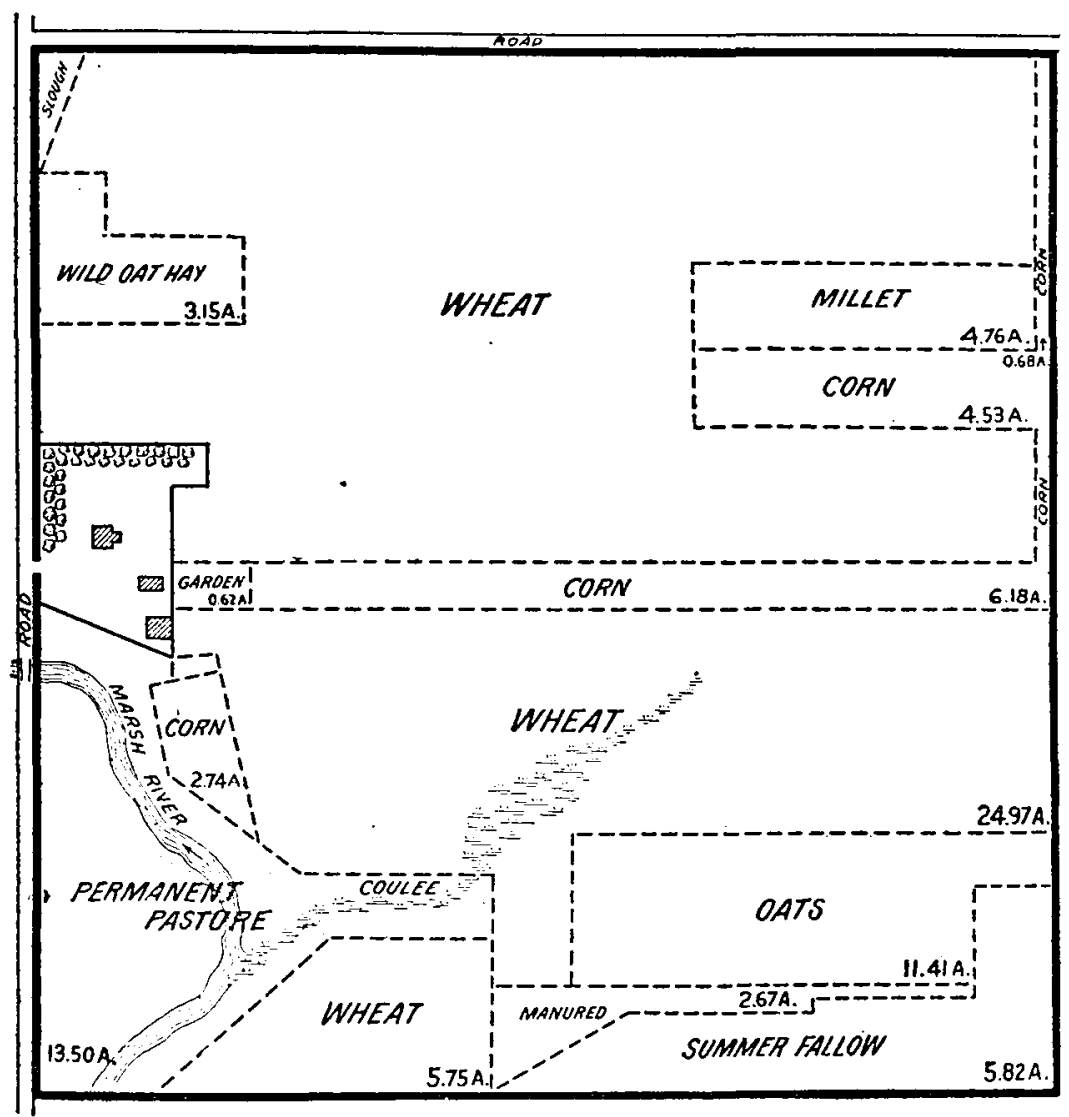

FIg. 41.-Anthony Farm. Original plan.

The intention is to keep about 15 cows, with some young stock, also 5 head of horses and 150 chickens.

\section{INSTRUCTOR'S CRITICISM.}

It will be observed from the above description and from figure 42 that there would be annually 60 acres of small grain, 45 acres grass and hay, and 15 acres of corn. While tllis may be a suitable rotation for that locality, it would seem that nearly the same amoint oi grass and grain could be raised in a 7-year rotation on seven 18 -acre fields, and this would be more economical, as it would save 1 fence and make 2 less fields on the farm, and besides the ficlds would be a little larger. Discussing such a change illustrates the fact that a farm can io cut up in many different ways to suit conditions 
and crop requirements. For example, suppose this farm is divided into 10 fields instead of 12 , as in figure 43, giving a 7-year rotation on 7 fields, each 18 acres in size. First year, corn; second year, wheat; third, fourth, and fifth years, grass; six th and seventh, corn with rape. Then on the 3 small fields you could have either a 6 -year or two 3-year rotations, or a 3-year rotation, as follows: First year, corn; second year, wheat; third year, clover. Since, however, clover often fails in this part of the State, a double-crop rotation could be used on these 3 fields, thus: First and second years, corn; third and fourth years, grain; fifth and sixth years, clover and timothy. This would give 1 crop of corn, 1 of wheat, and 1 of grass in each of the small felds

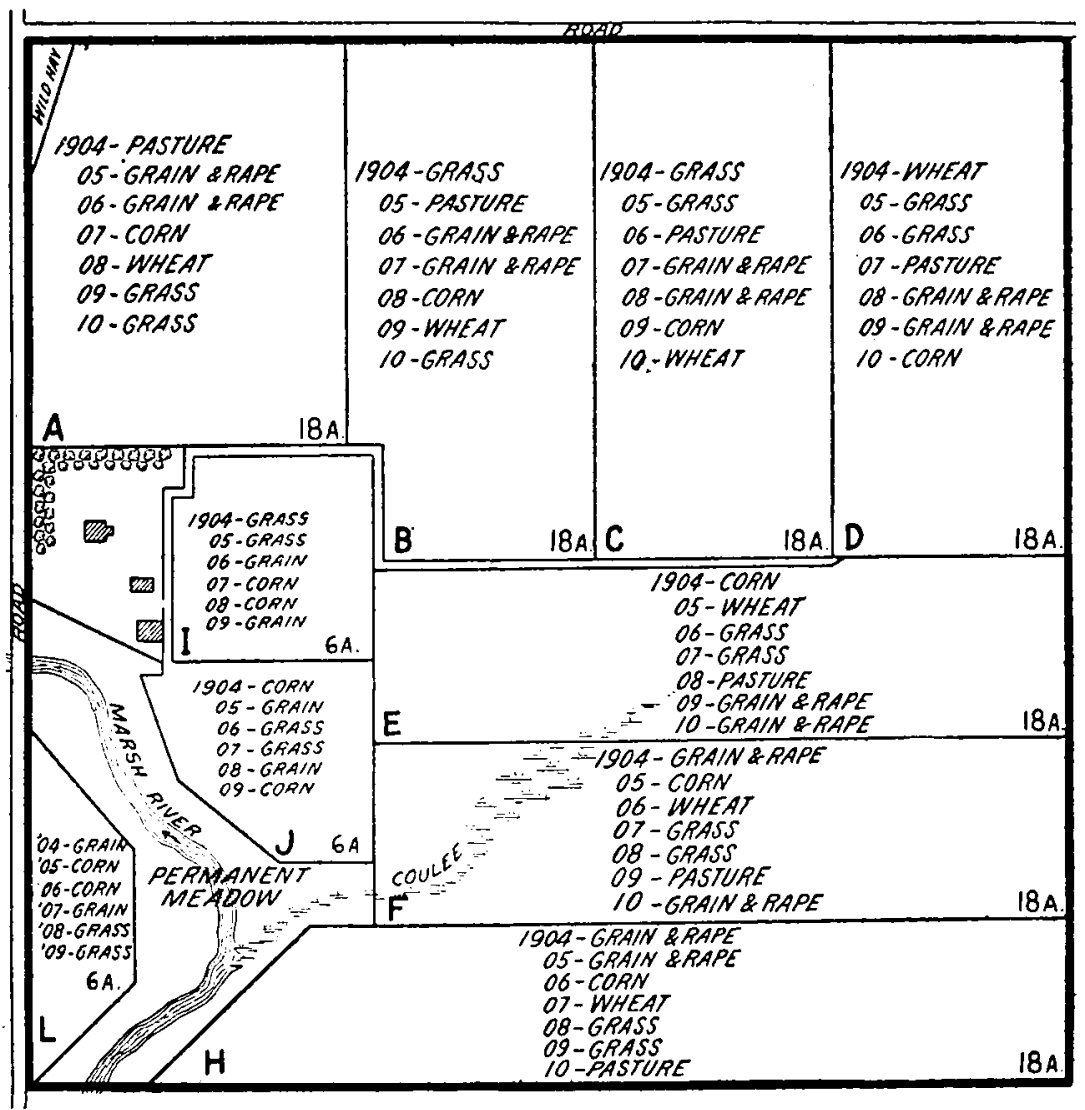

Fig. 42.-Anthony Farm. Key map to student's plan.

each year, while the timothy sown with the clover would nearly always give pasture or hay.

Still a better plan for the 3 fields would be to inaugurate a 6 -year rotation as follows: First year, corn; second year, grain; third and fourth years, grass; fifth year, grain; sixth year, corn. This gives a crop of grain, a crop of corn, and a crop of grass each year, keeps the grass seeded 2 years, and supplies the 2 grain crops.

\section{Whitney Farm.}

[Figs. 44, 45, and 46.]

This farm is located 30 miles north of Minneapolis, between Anoka and St. Francis. The Rum River runs through the southeast corner, cutting off 5 acres, which are used for permanent pasture. General farming is carried on, corn, oats, wheat, and hay being the chief crops grown. The live stock kept is about 40 cattle, 50 hoge, and 6 


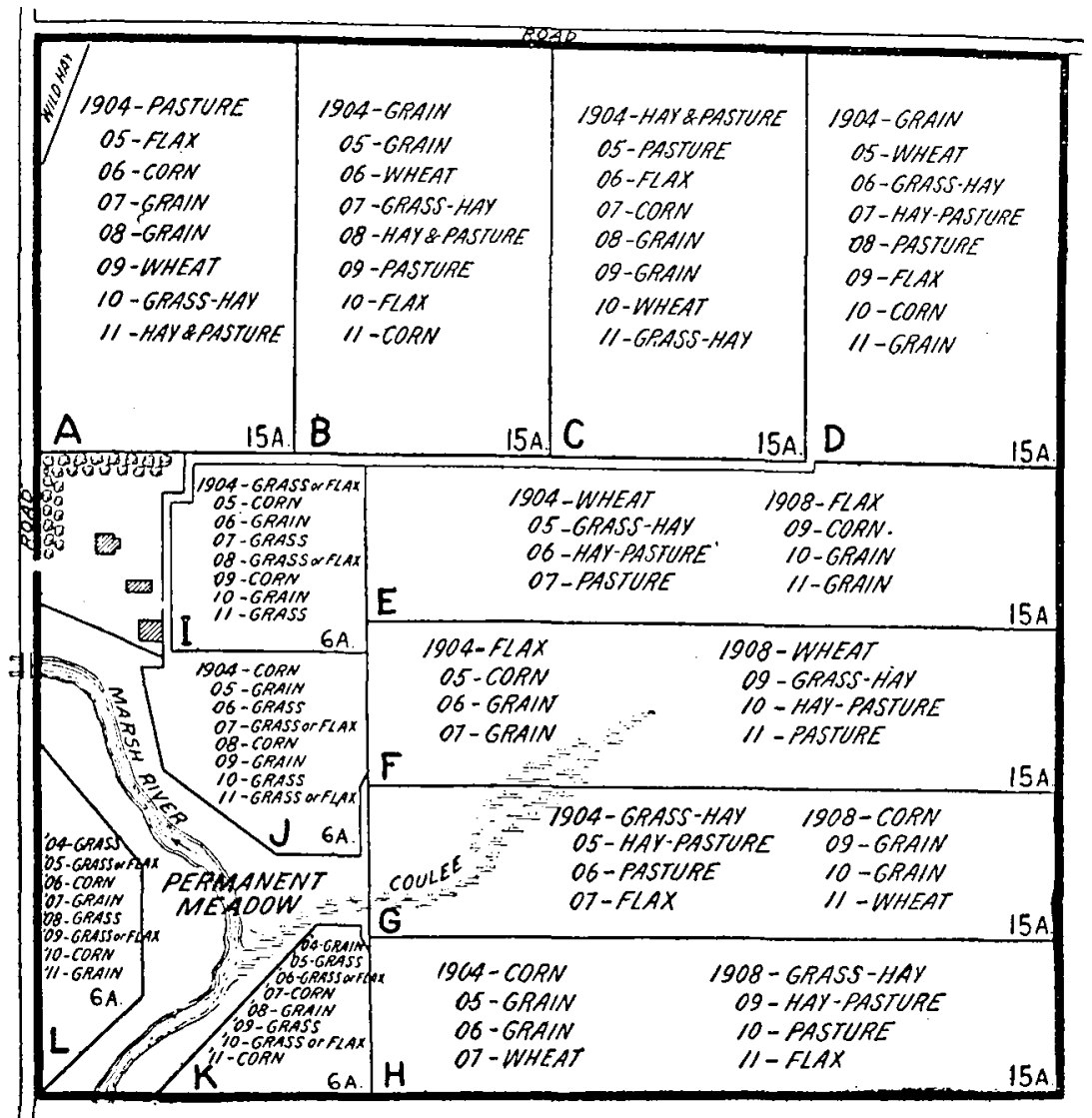

Fra. 43.-Anthony Farm. Key map to revised plan.

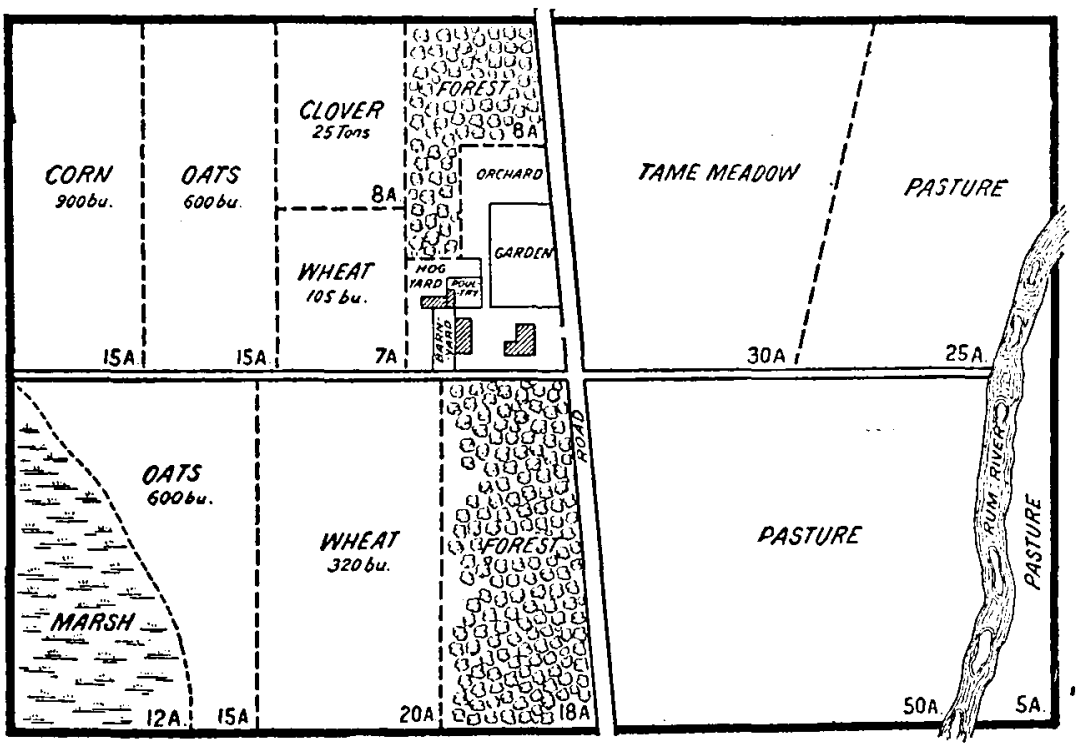


horses. About a dozen falt steers are narketed earh year No systematic rotation bas been followed, about half of the farm being devoted to grain and cultivated crops and the other half to hay and parture.

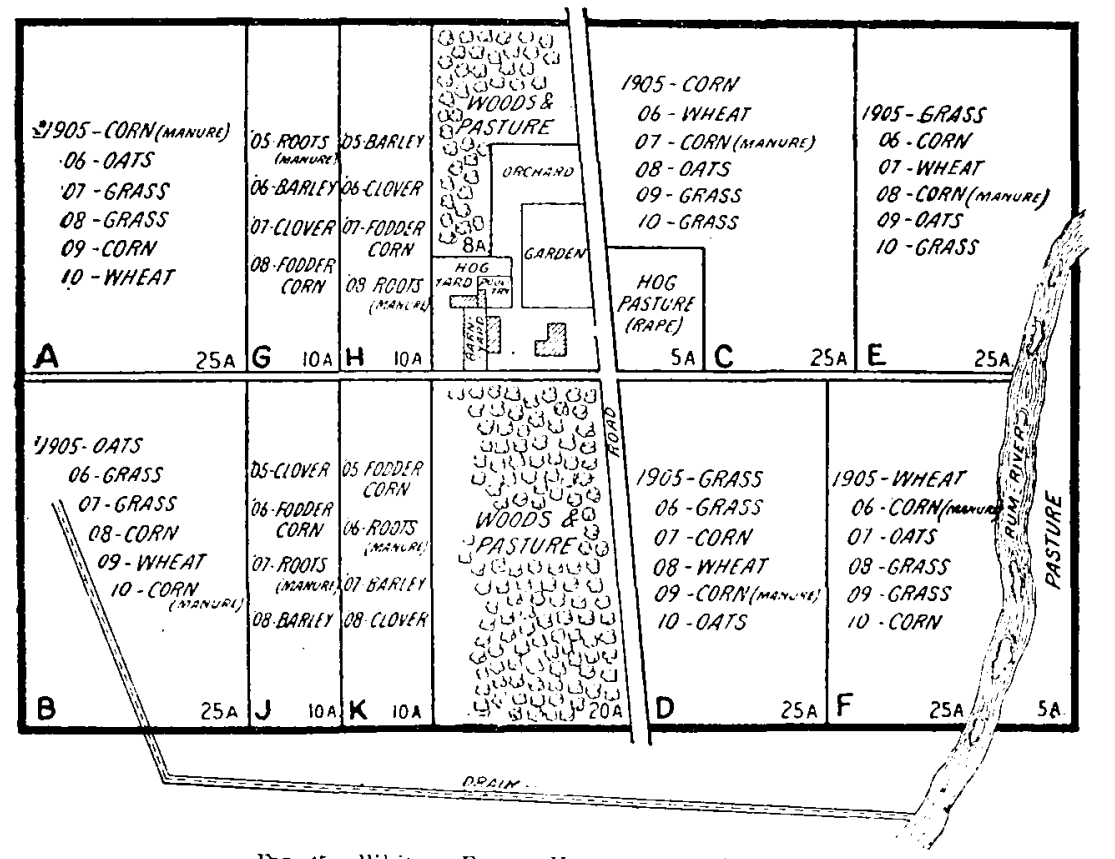

Fig. 45. Whitney Farm. hey unap to students plan.

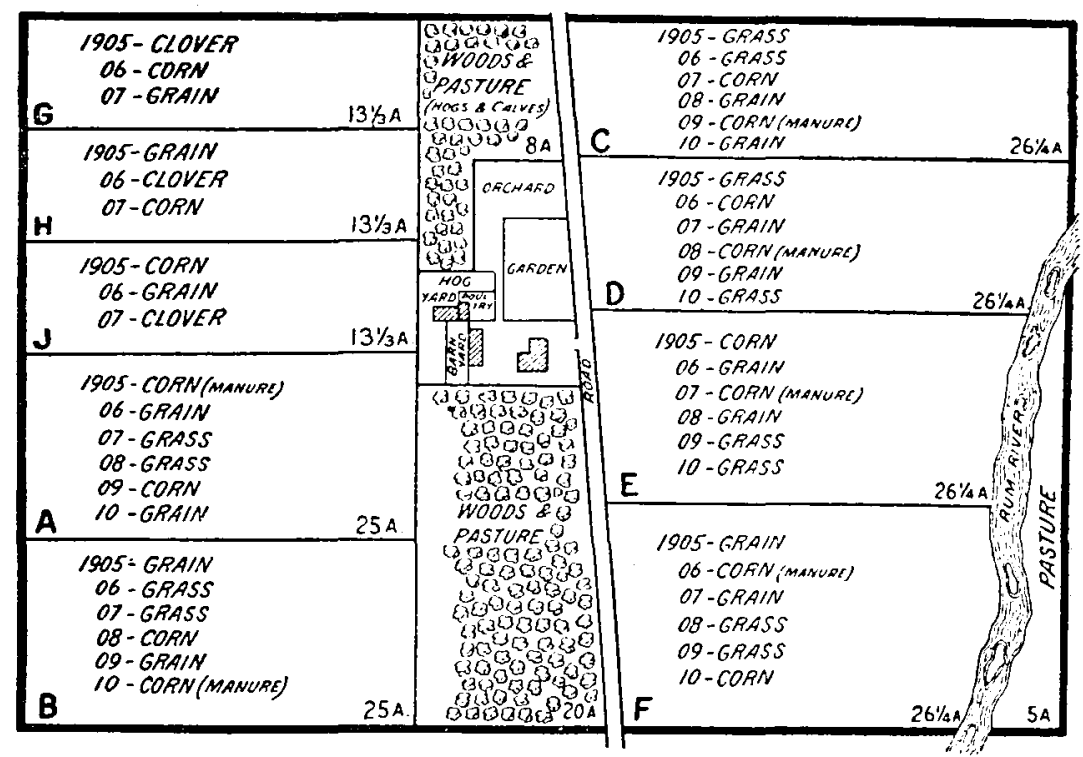

Flg. 46.-Whitney Farm. Key map to revised plun.

THE NEW PLAN.

In figure 45 is shown a plan under which the crops are brought under a systematic rotation in the year 1905 , with one 6 -field rotation and one 4 -field rotation. On the 
6 fields of 25 acres each the rotation is as follows: First year, corn; second year, wheat; third year, grass; fourth year, oats; fith and sixth years, grass. On the four 10-acre felds the rotation is: First year, root crops; second year, barley; third year, clover; fourth year, fodder corn. Ten acres are in the farmstead, 26 acres in woodland, and 5 acres are set aside for a hog pasture. The main road runs through the farm nearly north and south and a lane is planned to cut the farm at nearly right angles to the road that free access may be had to the fields and to the river.

\section{INSTRUCTOR'S CRITICISM.}

The 6-year rotation is good except that it might be better to change the terms wheat and oats to grain, which makes the rotation statement more flexible, allowing the use

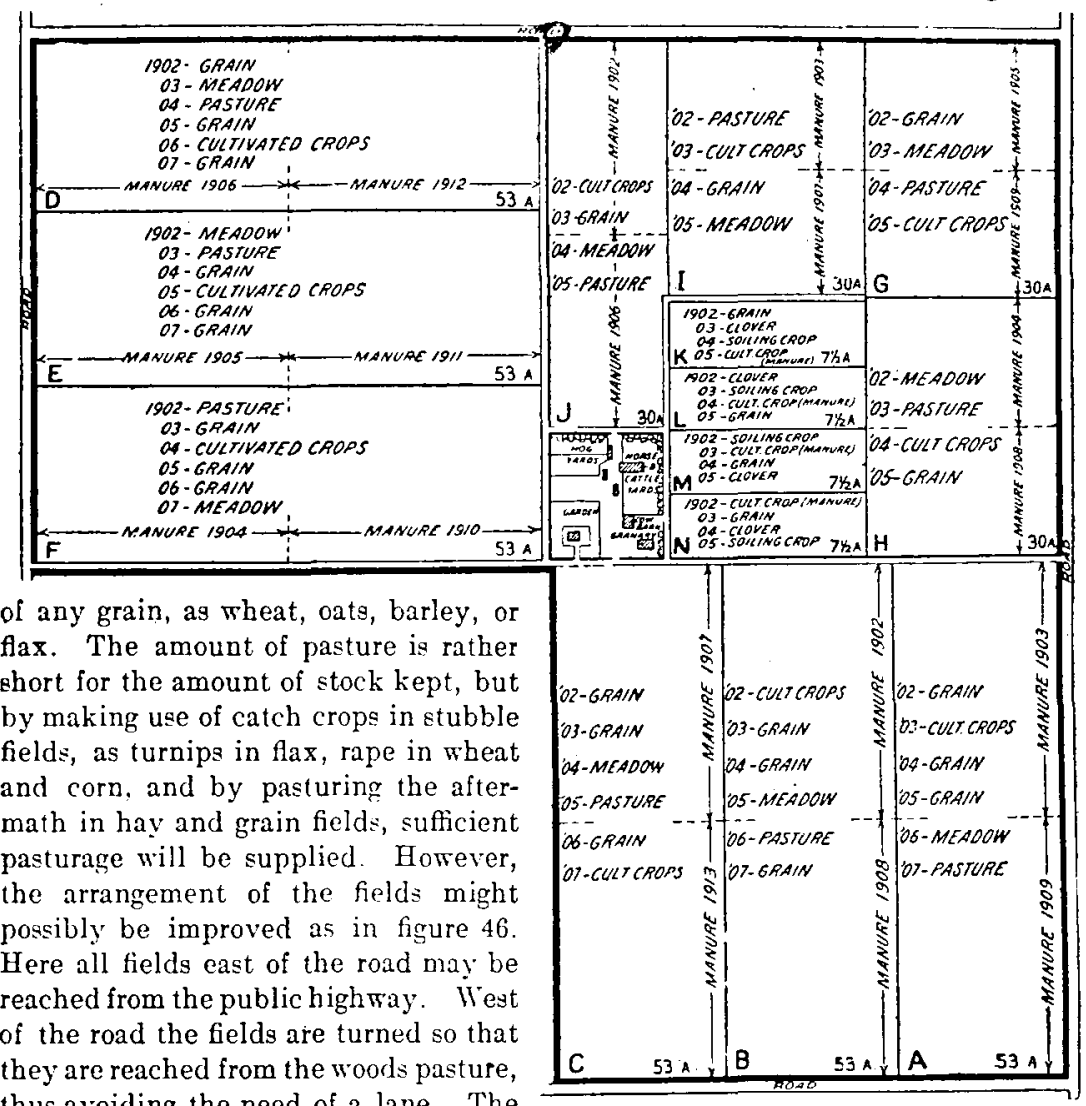

thus avoiding the need of a lane. The 40 acres for a minor rotation is changed to three 13-acre fields, connecting with

Fig: 47.-Anderson Farm. Key map to student's plan.

the north woods pasture, with a rotation as follows: First year, corn; second year, grain; third year, clover. This woods pasture seeded to white clover, alsike clover, Kentucky bluegrass, and timothy will furnish much pasture for hogs and calves, and whatever more can be used to advantage by these animals may be fenced off from one of the 3-year rotation fields. If desired, a part or all of the corn in this rotation could also be conveniently hogged off. 


\section{ANDERSON FARM.}

[Statement of Julius Anderson, fig. 47.]

This farm is situated in Renville County, Minn., in the town of Melville, in section No. 5, about 4 miles northeast from Bird Island. The farm contains 480 acres, of which 10 acres is farmstead, while the fields are to be divided into a system of 3 rotations: First, six 53-acre fields, A, B, C, D, E, and F; second, four 30-acre felds, G, H, $I, J$; third, four 7-acre fields, $K, L, M$, and $N$.

\section{THE STUDENT'S PLAN.}

1 intend to keep 12 working horses, 70 cattle, and 100 hogs. The horses will be - kept in the barn most of the time and will be fed on hay and oats with a small amount of corn. The cattle will be fed on grain, hay, and fodder corn in winter, and in summer they will be kent in the rotation pasture for 4 months and 1 to 2 months on annual pastures, especially rape sown among the grain crops on fields on which no grass is sown with the grain. For grain feed I will use barley, bran, and corn, with some roots and roughage. The pigs and calves will be kept on the field containing clover pasture in the rotation in fields $\mathrm{K}, \mathrm{L}, \mathrm{M}, \mathrm{N}$ in the spring and in the summer and fall in the field containing oats and peas, followed by rape. If necessary, I can put rape along with the grain crop in this rotation for fall pasture.

There will be sown 143 acres of wheat, all of which will be sold except that needed for flour and seed. There will be about 60 acres of corn, nost of which will be used for the hogs. The 33 acres of oats will nearly all be used for the horses. The 20 acres of barley will nearly all be fed to the pigs and cows with some for the horses.

\section{INSTRUCTOR'S CRITICISM}

The student says that when desired he can sow rape with the oats in fields $K, L$, $M$, and N. Since clover will have been seeded with the oats this is impracticable as the shade of the rape and the trampling of the stock while pasturing the rape would destroy the stand of clover designed for next year's crop. The student having failed to place all the rotation statements in their proper sequence in their respective fields, Table XV serves to enable both the student and the instructor to check up the crops in each field for each year and also to show how two crops may be grown in some of the fields and to state other facts both in projecting a plan and in writing the history of what was actually grown on the farm. 
TABLE XV.-Sequence of rotations on the Anderson Farm.

SIX-ELELD ROTATION.

\begin{tabular}{|c|c|c|c|c|c|c|c|c|c|c|c|c|}
\hline \multirow[b]{2}{*}{$\underset{0}{\stackrel{0}{0}}$} & \multicolumn{2}{|l|}{1902} & \multicolumn{2}{|c|}{1903} & \multicolumn{2}{|l|}{1904} & \multicolumn{2}{|l|}{1905} & \multicolumn{2}{|l|}{1906} & \multicolumn{2}{|l|}{1907} \\
\hline & Crop. & 总 & Crop. & 总 & Crop. & 总 & Crop. & 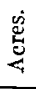 & Crop. & $\stackrel{\dot{g}}{5}$ & Crop. & 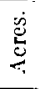 \\
\hline A. . & Wheat. & 53 & Corn.. & 53 & $\begin{array}{l}\text { Oats.... } \\
\text { Barley.. }\end{array}$ & $\begin{array}{l}33 \\
20\end{array}$ & Wheat. & 53 & Grass. & 53 & $\begin{array}{c}\text { Pasture, } 45 \\
\text { eattle, } 4\end{array}$ & 53 \\
\hline B.. & Corn. & 53 & Oats.... & $\begin{array}{l}33 \\
20\end{array}$ & Wheat.. & 53 & Grass... & 53 & Pasture. & 53 & wheat... & 53 \\
\hline C.. & $\begin{array}{l}\text { Oats...... } \\
\text { Barley.... }\end{array}$ & $\begin{array}{l}33 \\
20\end{array}$ & Wheat.. & 53 & Grass... & 53 & Pasture. & 53 & Wheat.. & 53 & Corn. & 53 \\
\hline D.. & Wheat.... & 53 & Grass. & 53 & Pasture. & 53 & Wheat. & 53 & Corn. & 53 & Oats. & 33 \\
\hline E.. & Grass..... & 53 & Pasture. & 53 & Wheat. & 53 & Corn. & 53 & Oats... & 33 & Wheat.... & 53 \\
\hline F.. & Pasture... & 53 & Wheat.. & 53 & Corn.. & 53 & $\begin{array}{l}\text { Oats...... } \\
\text { Barley.... }\end{array}$ & $\begin{array}{l}33 \\
20\end{array}$ & Wheat... & 53 & Grass.... & 53 \\
\hline
\end{tabular}

FOUR-FIELD, 30ACRE ROTATION.

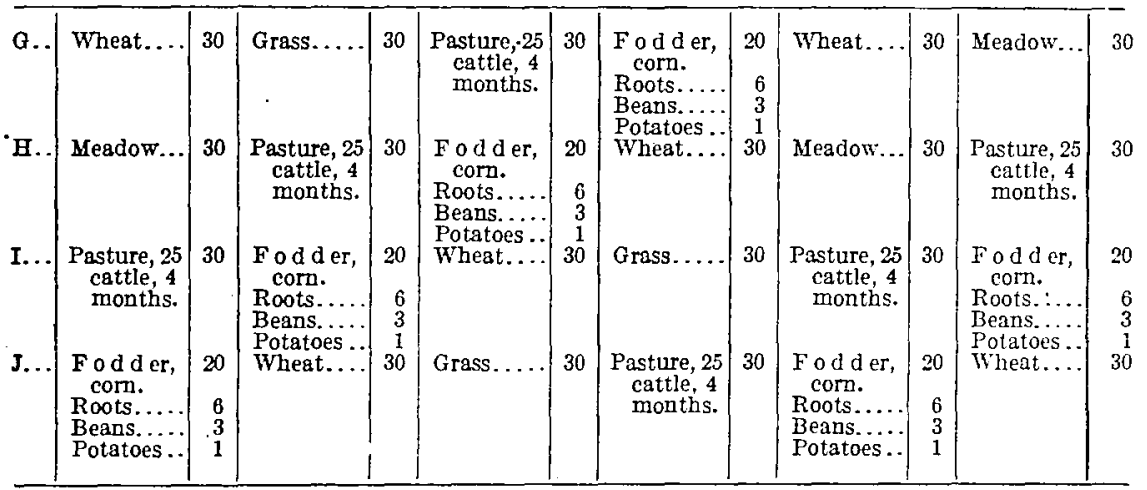

FOUR-FIELD, 7-ACRE ROTATION.

\begin{tabular}{|c|c|c|c|c|c|c|c|c|c|c|c|c|}
\hline K. . & Wheat.... & 7 & $\begin{array}{c}\text { C lover } \\
\text { pa sture } \\
\text { lor } 100 \\
\text { pigs and } \\
20 \text { spring } \\
\text { c al ves } \\
\text { for 2h } \\
\text { months. }\end{array}$ & 7 & $\begin{array}{l}\text { Oats, peas, } \\
\text { rape; for } \\
\text { pa stur- } \\
\text { ing } 100 \\
\text { pigs and } \\
20 \text { calves } \\
\text { the next } \\
21 \text { mo's. }\end{array}$ & 7 & Corn, ... & 7 & Wheat.... & 7 & $\begin{array}{l}\text { C I o v e r } \\
\text { pasture } \\
\text { for } 100 \\
\text { pigs and } \\
20 \text { calves } \\
\text { for } \mathbf{r} 2 \\
\text { months. }\end{array}$ & 7 \\
\hline ... & $\begin{array}{c}\text { C } 1 \text { o v e r } \\
\text { pasture, } \\
\text { as above. }\end{array}$ & 7 & $\begin{array}{l}\text { Oats, peas, } \\
\text { rape, as } \\
\text { above. }\end{array}$ & 7 & Corn..... & 7 & Wheat.... & 7 & $\begin{array}{r}\text { C lo v e r } \\
\text { pasture, } \\
\text { as above. } \\
\text { Oats, peas. }\end{array}$ & 7 & $\begin{array}{l}\text { Oats, peas, } \\
\text { rape, as } \\
\text { above. } \\
\text { Corn }\end{array}$ & 7 \\
\hline N.. & $\begin{array}{c}\text { Uats, peas, } \\
\text { rape, as } \\
\text { above. } \\
\text { Corn...... }\end{array}$ & 7 & Wheat.... & 7 & $\begin{array}{l}\text { Clo v e r } \\
\text { pasture, } \\
\text { as above. }\end{array}$ & 7 & $\begin{array}{l}\text { pasture, } \\
\text { as above. } \\
\text { Oats, peas, } \\
\text { rape, as } \\
\text { above. }\end{array}$ & 7 & $\begin{array}{c}\text { rape, as } \\
\text { above. } \\
\text { Corn....... }\end{array}$ & 7 & Wheat.... & 7 \\
\hline
\end{tabular}




\section{HATHAWAY FARM.}

[Statement by F. C. Hathaway, figs. 48 and 49 .]

This is a square 160-acre farm situated north of Winnebago City, in Blue Earth County, Minn. The fields are badly cut up at present by a number of sloughs, making the farm quite wet, but all these can be drained easily and this will be done soon. It has fair buildings, consisting of a house, barn, and granary.

A strictly grain line of farming has been carried on here for 30 years and the land is badly run down, but was bought with the intention of making it a stock farm. By

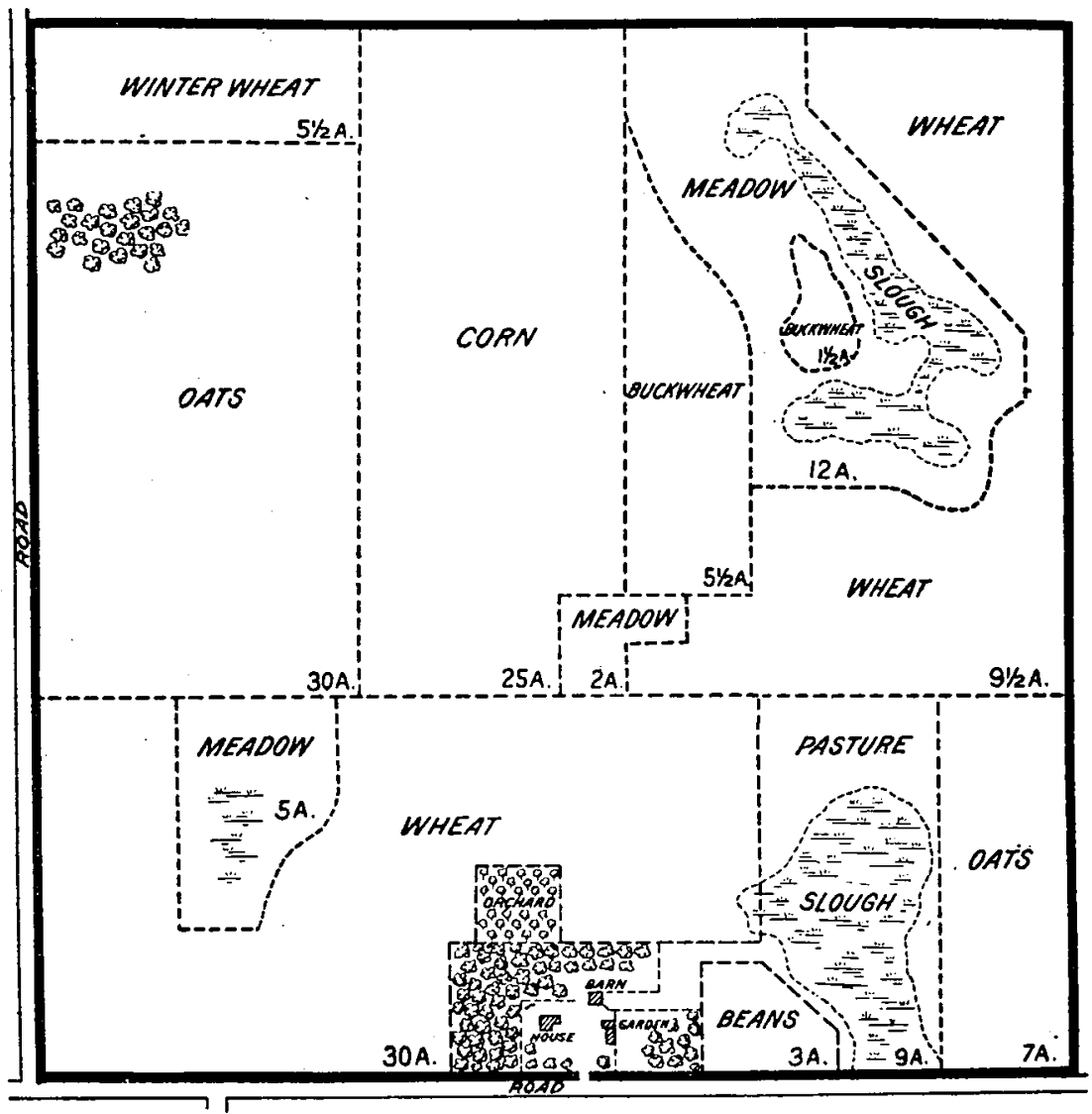

Fra. 48.-Hathaway Farm. Original plan.

judicious handling we expect soon to get good results from our work in the way of animal products. It is planned to keep 4 horses, 5 cows, 12 steers, and $\mathbf{4 0}$ to $\mathbf{5 0}$ hogs, and also to feed a large number of sheep in the fall on rape and other autumn pastures.

\section{THE NEW PLAN.}

In order to get the farm into any kind of a rotation it will first be necessary to drain the sloughs. It will also require 2 or 3 years' preparation, so that the old meadows may be broken up ready for cropping and new meadows and pastures seeded for the starting of the rotation. The little patch of woods in the northwest corner will be cleared up, that we may have good regular fields.

The rotation as completed for 1906 is a 5-year rotation, each field to be 20 acree in size. The northeast field, in which the big slough was, is to be seeded to brome 
and other grasses for permanent pasture, hence will not be considered in the rotation, which is: First year, corn; second year, oats; third year, corn; fourth year, barley, fifth year, clover. The 6 smaller fields accommodate two 3-year rotations, one on each side of the farmstearl, and are designed simply for temporary hog and sheep pastures during the summer months. One rotation is: First and second years, grain; third year; chover; and the other is: First year, grain; second year, clover; third year, garden. The fields are all arranged for greatest convenience, as I see it.

IYSTRUCTOR'S CRITICISM.

The general plan you have adopted is very good and if, as you suggest, enough live stock is kept to utilize all of the feed the farm will produce, you should be able with

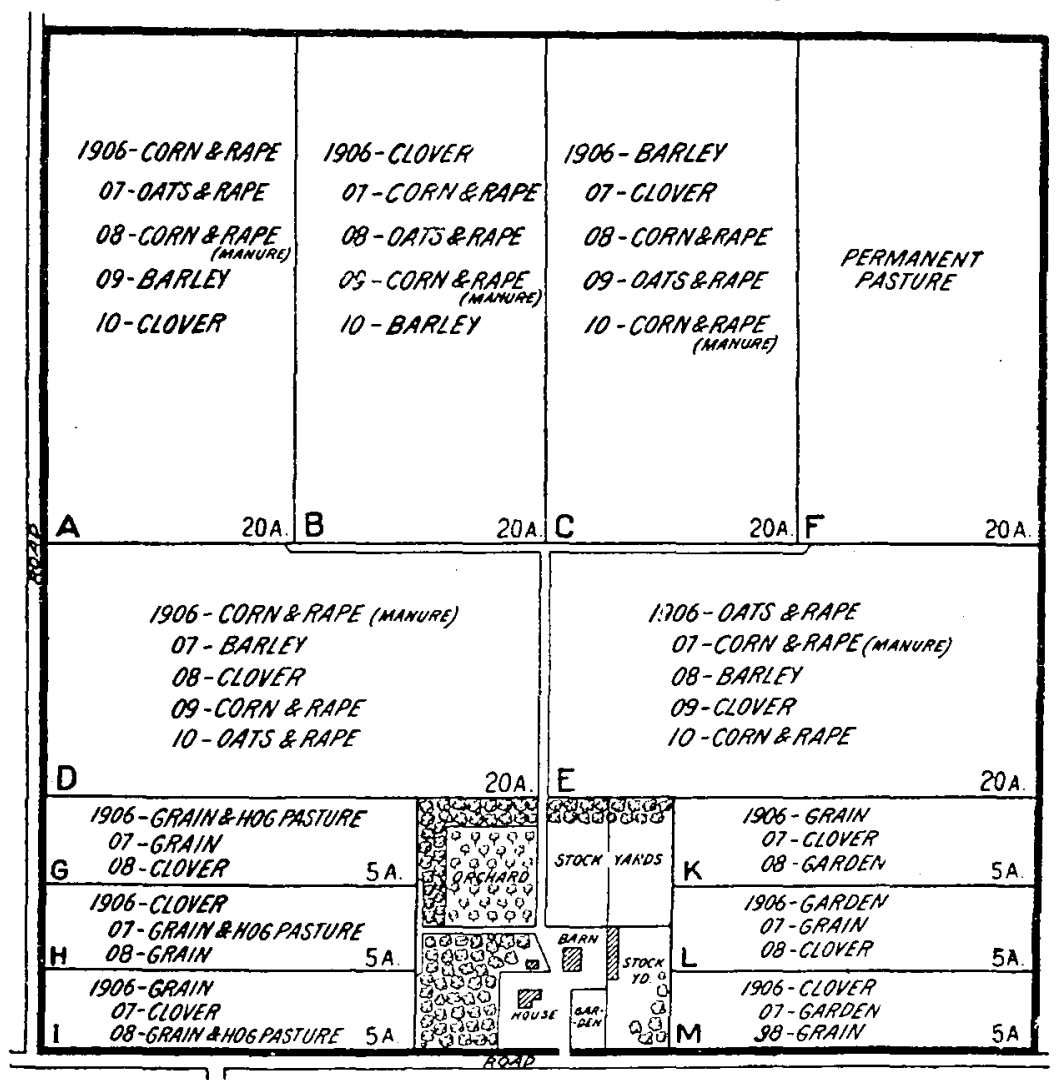

Fig. 49. - Hatbaway Farm. Key map to student's plan.

this rotation to build up the productivity of the soil sufficiently within a few years to insure profitable yields. The terms barley and oats should be changed to the more general term, grain, as this gives a little more flexibility to the rotation without in any way impairing its value.

It will pay you to invest up to $\$ 20$ to $\$ 50$ per acre to drain the permanent pasture so that this field may also be tillable, for another year of grass and the effect of pasturing will be valuable to the other fields. This would allow you a 6 -year rotation with 2 years of grass in place of 1 as you now have it. This would undoubtedly increase the average yields of all crops other than grass, and the rotation pastures would doubtless yield more than permanent pasture as on field $F$. Were you to invest $\$ 400$ in draining that 20 acres and the drain were properly and carefuly laid you would then 
have a permanent improvement, increasing by much more than that sum the value of your farm. The amnual charge agranst this improvement would be only interest on the investment, which at 6 per cent would be $\$ 24$. If the change of rotation made possible by this drainage would result in an increased yield of 24 cents per acre per year on each of the other five 20-acre fields, the investment would be warranted, to say nothing of the improvement on the 20 acres drained. Another advantage to be gained by draining this field would be that you could then change the 4 north fields to lie east and west. $\Lambda$ lane extended straight north 80 rods from the farmstead would reach all 4 fields without a turn and would save 40 square rods of land and 40 rods of fencing.

The minor rotations are all right if they provide the crops needed, but while well arranged they are not as practical as they should be. Let us assume that they furnish the crops wanted as pasturage, grain, and clover. The 5-acre garden in your locality would likely be impractical, especially as you have a garden in the farmstead, unless garden be used very broadly, covering potatoes, sweet corn, or beans. The cost of

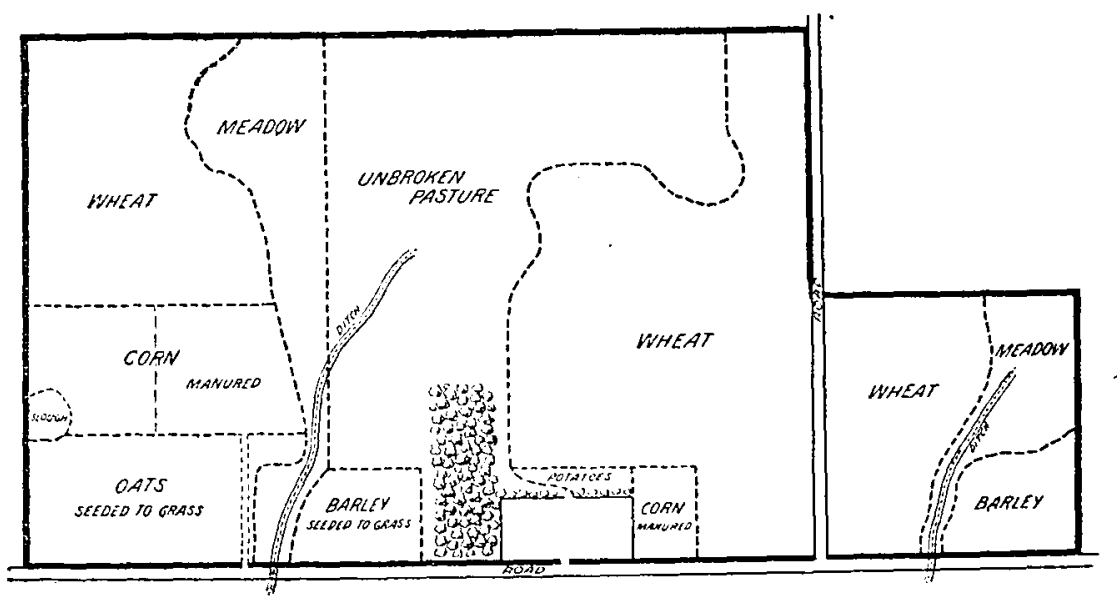

FIG. 50.-Ash Grove Farm. Original plan in 1901.

fencing would be reduced if you would make a 4-year rotation by making 2 fields on each side of the farmstead instead of 3 , and use but one rotation. I would suggest the following 4-year rotation for the four $7 \frac{1}{2}$-acre fields: First year, grain; second year, clover; third year, corn and rape; fourth year, corn and rape. The clover would be pastured by hogs or other stock. One or both of the two $7 \frac{1}{2}$-acre fields of corn and rape could be fed off by the hogs or sheep. This combination of 2 crops harvested by the animals themselves often yields a very handsome net profit per acre.

\section{Ash Grove Farm.}

[Statement lig F. B. Headley, figs. 50, 51, 52, 53, 54, and 55.]

\section{THE STUDEN'T'S PLANS.}

Ash Grove Farm is located in Book Lake Township, Renville County, Minn. The farm contains 280 acres, all of which can be cultivated. The rotations, as indicated in figure 54, provide 40 acres of hay, 40 acres of corn, and about 80 acres of pasture, also 20 acres of rape each fall for young stock. This should feed about 60 head of cattle, half of which will be milk cows. Six work horses and one roadster will be kept. The intention is to market about 30 hogs each year. Some wheat will be sold, but all other products will be fed on the farm. The small fields, $K, M$, and $N$, are intended for hog pasture. 
INSTRUCTOR'S CRITICISM.

Mr. Headley's plans show how a farm may gradually be developed and the fences be erected while the complete plans are being put into operation. Thile these plans are excellent, the fields have been made smaller than necessary, and hence there is a waste of fence material. The plan projected in figure 54 shows the acreage and crops, as follows:

Pasture.................. $\quad 80$

Hay....................... 40

Wheat

Corn....................... 40

Barley and oats.................. 26

By dividing the farm as indicated in figure 55 into six 40 -acre fields, $A, B, C, D, E$, and $F$, and putting a 6 -year rotation on the 6 large fields and a 6 -year rotation on the 3 small fields, as indicated, he would have the average shown in Table XVI.

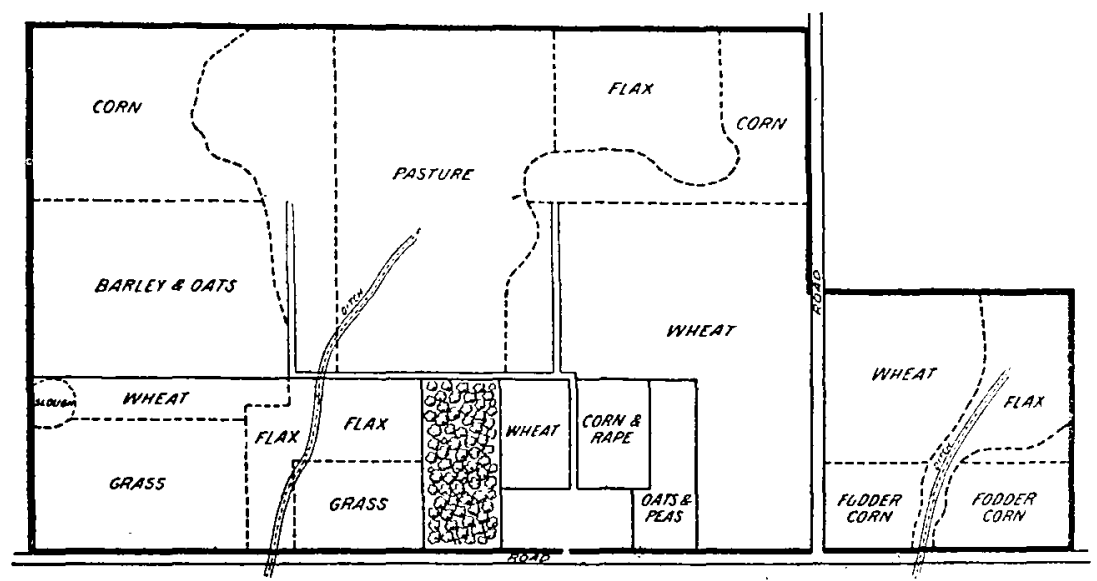

FTg. 51.-Ash Grove Farm. Transition plan in 1902.

TABLE XVI.-Revised scheme of crop rotations for Ash Grove Farm.

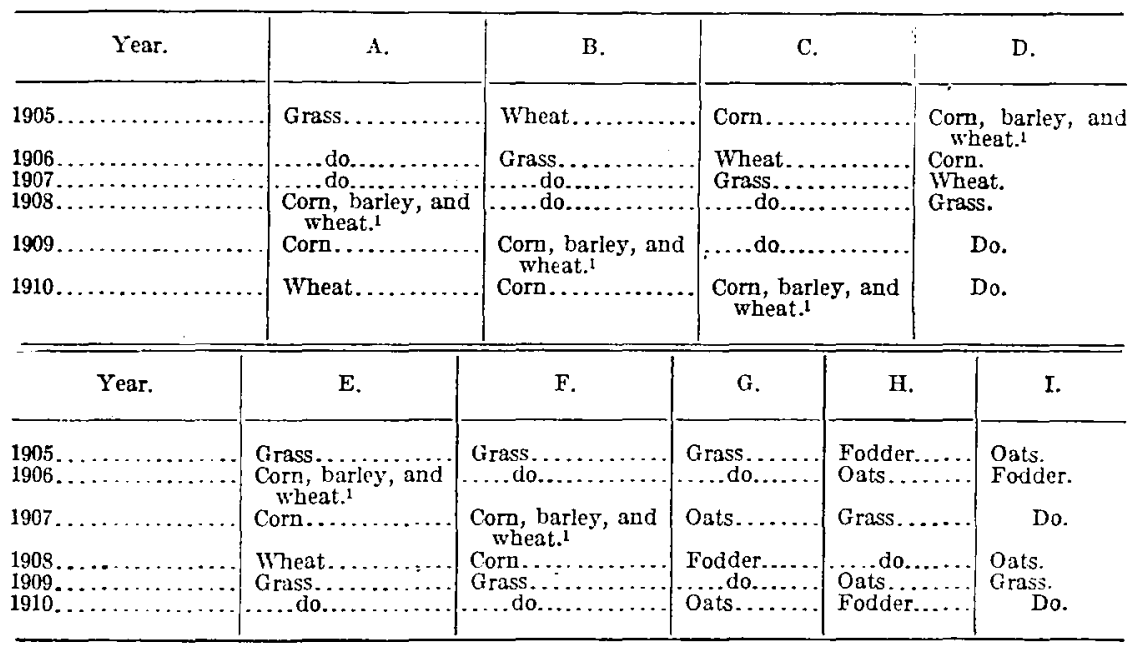




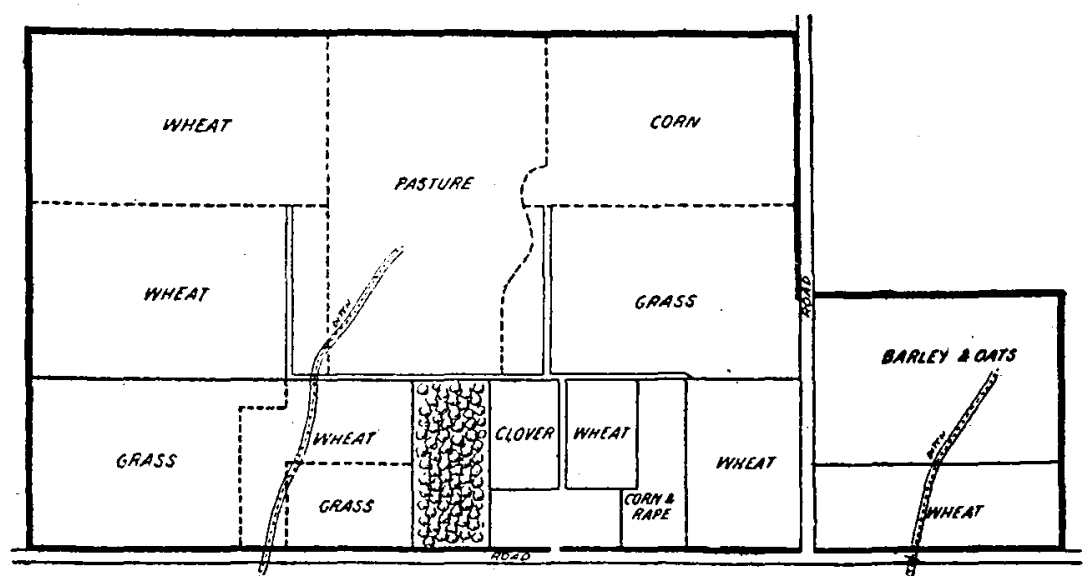

FIG. 52.-Ash Grove Farm. Transition plan in 1903.

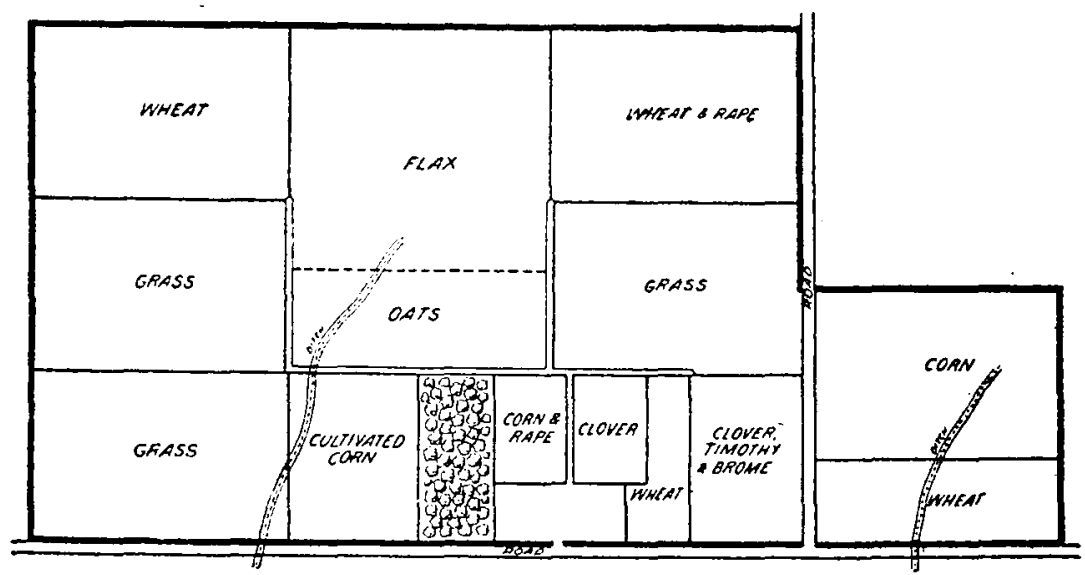

Fig. 53.-Ash Grore Farm. Transition plan in 1904.

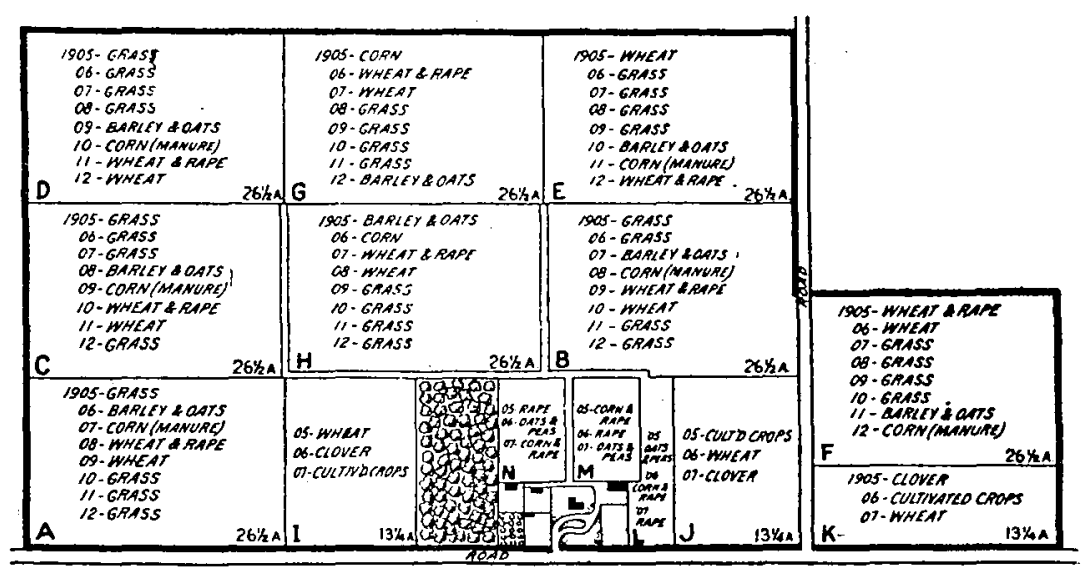

Fia. 54.-Ash Grove Farm. Key map to studen't's plan, 1905-1912. 
Thus we get annually:

88 acres grass.

40 acres hay.

40 acres rape

48 acres corn.

60 acres wheat.

28 acres oats and barley.

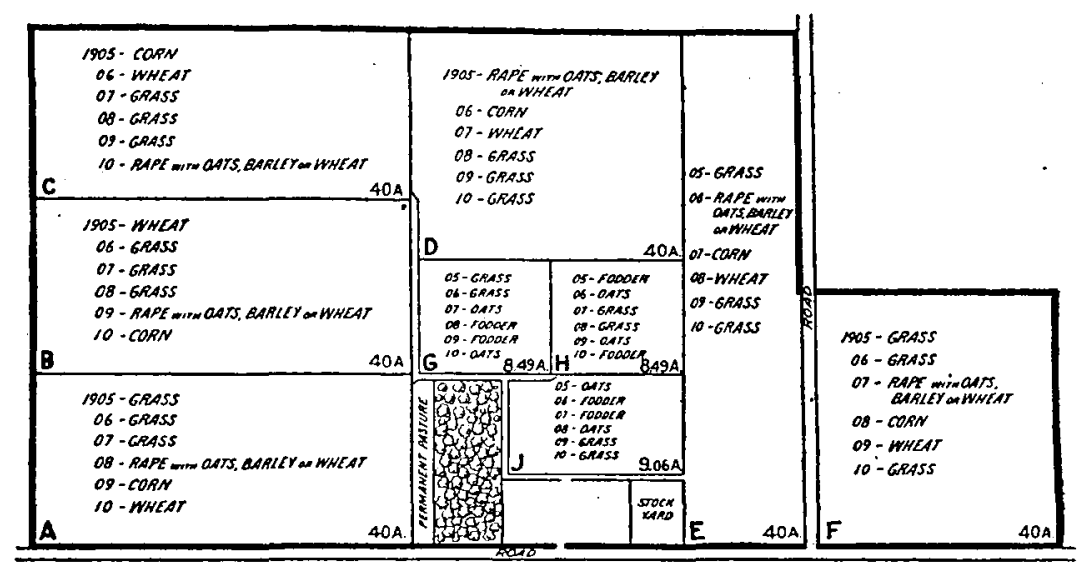

FIG. 55. $-\Lambda$ sh Grove Farm. Key map to revised plan.

It requires 1,200 rods of fence, not taking outside fences into account, to inclose felds and lanes according to figure 54, while according to figure 55,900 rods fences the fields just as satisfactorily and also gives more rape for autumn pasturage.

\section{Pomme de Terre Farm.}

[Statement by Mfr. Hall, figs. 56 and 5i.]

This 240-acre farm is near Morris, Stevens County, Minn. The land is now all tillable, as a large ditch was put through the west 80 last year. This is to be tiled the coming summer in order to have regular fields. The buildings are in good repair and consist of a house, barn,

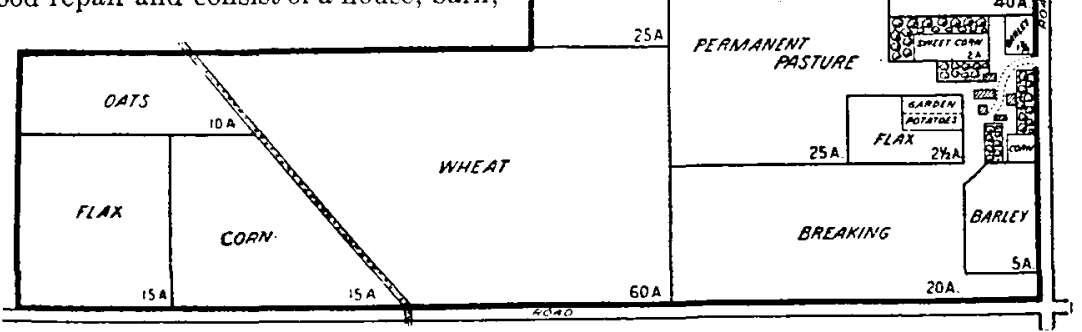

FIg. 56.-Pomme de Terre Farm. Original plan.

hog house, machine shed, and shop. The fields are divided as shown in figure 56. The farm heretofore has been devoted almost entirely to grain raising, little live stock other than the necessary horses for the operation of the farm being kept. 
THE NEW PLAN.

No rotation bas ever been iolluwed, but one is planned, as in fgure 57 that all grain and roughage may be fed to stuck and not sold directly from the farm. It is estimated that the farm under this rotation will support 35 head of cattle and 50 sheep, also the product of 10 brood sows each year. A rotation on four 40-acre fields is to be as follows: First year, corn; second year, wheat; third and fourth years, meadow and pasture. There are two ofher rotations, one a 3-year rotation on three 20-acre fields: First year, corn; second year, grain, third year, clover. The other is a 4-year rotation on four $2 \frac{1}{2}$ acre plats: First year, corn; second year, fodder corn; third year, roots; fourth year, wheat.

INSTRUCTOR'S CRITICISM.

Your new arrangement of fields is very good, yet a simpler rotation would

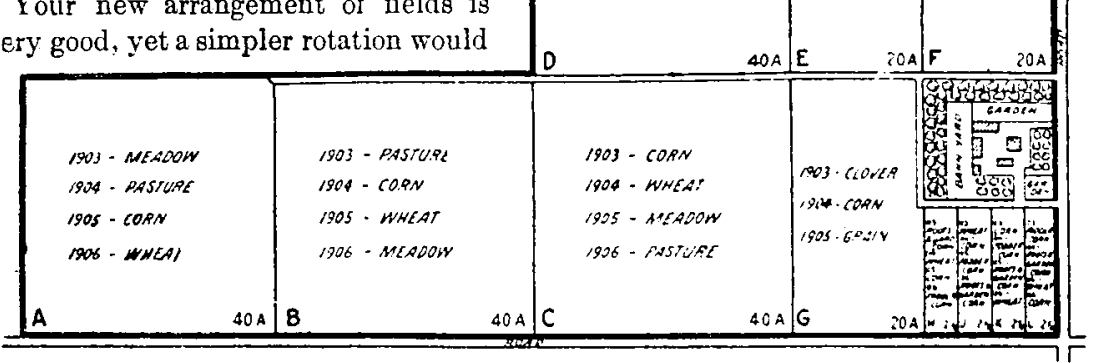

Fig. 57.-Ponme de Terre Farm. Key map to new plan.

be likely to give you better satisfaction. Would suggest that you use the two 20 acre fields in the northeast cormer for a 40-acre field, changing the rotation on your larger fields to a 5-year rotation instead of four, as follows: First year, corn; second year, grain; third and fourth years, meadow and pasture; fith year, grain. This would give you 80 acres of grain in place of 40 , would be a less radical change from your former system of cropping, and would probably pay better in your vicinity.

The 4-year rotation on the small fields too rapidly reduces the vegetable matter in the soil. Would do away with the 4-year rotation, giving three 10-acre fields, east, southeast, and south of the farmstead, for the following 3-year rotation: First year, corn; second year, grain; third year, clover. Such cultivated crops as you desire to grow, as roots and potatoes, could be put in the cornfield in one of the other rotations. 
